\title{
Integrated pest management: good intentions, hard realities. A review
}

\author{
Jean-Philippe Deguine ${ }^{1}$ (D) - Jean-Noël Aubertot ${ }^{2} \cdot$ Rica Joy Flor $^{3} \cdot$ Françoise Lescourret $^{4}$. \\ Kris A.G. Wyckhuys ${ }^{5}$. Alain Ratnadass ${ }^{6,7}$
}

Accepted: 29 March 2021 / Published online: 11 May 2021

(C) The Author(s) 2021

\begin{abstract}
Integrated Pest Management (IPM) provides an illustration of how crop protection has (or has not) evolved over the past six decades. Throughout this period, IPM has endeavored to promote sustainable forms of agriculture, pursued sharp reductions in synthetic pesticide use, and thereby resolved myriad socio-economic, environmental, and human health challenges. Global pesticide use has, however, largely continued unabated, with negative implications for farmer livelihoods, biodiversity conservation, and the human right to food. In this review, we examine how IPM has developed over time and assess whether this concept remains suited to present-day challenges. We believe that despite many good intentions, hard realities need to be faced. 1) We identify the following major weaknesses: i) a multitude of IPM definitions that generate unnecessary confusion; ii) inconsistencies between IPM concepts, practice, and policies; iii) insufficient engagement of farmers in IPM technology development and frequent lack of basic understanding of its underlying ecological concepts. 2) By diverting from the fundamental IPM principles, integration of practices has proceeded along serendipitous routes, proven ineffective, and yielded unacceptable outcomes. 3) We show that in the majority of cases, chemical control still remains the basis of plant health programs. 4) Furthermore, IPM research is often lagging, tends to be misguided, and pays insufficient attention to ecology and to the ecological functioning of agroecosystems. 5) Since the 1960s, IPM rules have been twisted, its foundational concepts have degraded and its serious (farm-level) implementation has not advanced. To remedy this, we are proposing Agroecological Crop Protection as a concept that captures how agroecology can be optimally put to the service of crop protection. Agroecological Crop Protection constitutes an interdisciplinary scientific field that comprises an orderly strategy (and clear prioritization) of practices at the field, farm, and agricultural landscape level and a dimension of social and organizational ecology.
\end{abstract}

Keywords IPM · Crop protection · Agroecology · Agroecological crop protection · Reduction of pesticides · Social ecology · Food systems $\cdot$ Research approaches $\cdot$ Pesticides

Jean-Philippe Deguine

jean-philippe.deguine@cirad.fr

CIRAD, UMR PVBMT, F-97410 Saint Pierre, La Réunion, France

2 INRAE, UMR AGIR, CS52627, F-31326 Castanet-Tolosan Cedex, France

3 Sustainable Impact Platform, International Rice Research Institute, IRRI-Cambodia Office, Toul Kork, Phnom Penh 12158, Cambodia

4 INRAE, UR1115, Domaine Saint-Paul, Site Agroparc, 84914 Avignon Cedex 9, France

5 Chrysalis Consulting, Hanoi, Vietnam

6 CIRAD, UPR HortSys, F-97455 Saint-Pierre, La Réunion, France

7 HortSys, Univ. Montpellier, CIRAD, Montpellier, France

\section{Contents}

1. Introduction

2. Sixty years of IPM

2.1. Conception and development of IPM

2.2. A quasi-infinite number of definitions and interpretations

3. IPM roadblocks and adoption barriers

3.1. Weak farmer knowledge base

3.2. User preferences and risk aversion

3.3. Vested interests and corporate responsibility

3.4. Traditional practices and emerging IPM technologies

3.5. Hard and soft policy levers

3.6. Cultural barriers and the decline of public interest science

4. Inconsistencies between concepts and practices in IPM 
4.1. Integration or juxtaposition of practices?

4.2. The pervasiveness of chemical protection

4.3. The IPM nebula

5. Inadequate research on IPM

5.1. Gaps in research programs

5.2. Gaps in scientific approaches

6. Inadequate consideration of ecology in IPM

6.1. A move away from the roots of ecology towards chemicals

6.2. Calls for more ecology in crop protection

7. Agroecological Crop Protection (ACP): towards a paradigm shift

7.1. Origins and definition of ACP

7.2. Case studies

7.3. Moving from IPM to ACP

8. Conclusion

Acknowledgements

References

\section{Introduction}

Since the end of the Second World War, in the Northern hemisphere, agriculture has undergone a significant intensification faced with demands for increased production. The Green Revolution proposed by William Gaud in 1968 advocates substantial use of inputs, in particular synthetic pesticides (Jain 2010), and this trend continues today in the Global north and Global south countries. Since the 1990s, the concept of a "doubly" green revolution demonstrates the desire to embrace environmental concerns (Conway 1997; de Schutter and Vanloqueren 2011), but production, performance, and profitability remain the priority (Horlings and Marsden 2011). Today, the concept of sustainable intensification proposed by Sir Gordon Conway (Conway 1999) and the "Montpellier Panel" (Conway et al. 2013) has been put forward for Africa (Pretty et al. 2011; Ratnadass 2020). This sustainable intensification has been under development since then, reflecting the various degrees of agricultural sustainability, as well as the different levels of inputs. Struik and Kuyper (2017) believe that there are today two main options for the sustainable intensification of agriculture: one which aims to "de-intensify" agroecosystems with high inputs, and the other which aims to increase the level of inputs in situations where there is a need to increase yields. Participatory modeling approaches which combine expert and scientific knowledge (Aubertot and Robin 2013; Vayssières et al. 2011) have the potential to promote innovation in such options because they allow i) uncertainties to be explicitly in these contexts recognized; ii) local factors to be incorporated; and iii) a broader study framework including the social and ecological scope of agricultural activities (Thérond et al. 2015). These approaches allow a rigorous scientific framework to be applied which combines expert knowledge (from practitioners such as farmers and advisers) and scientific knowledge (scientific and technical publications, datasets obtained from field experiments, or diagnoses of commercial fields, and existing simulation models).

Sustainability is at the heart of the debates about agriculture debate. However, for several decades, and in particular since the Rio de Janeiro Conference in 1992, it has been recognized that the sustainability of ecosystems in general, and agroecosystems in particular, depends on ecosystem health and functioning, of which the driving force is biodiversity (namely plant, animal and microbial communities - the latter represented by fungal, bacterial and viral organisms). That was nearly 30 years ago and we can make identical observations today (see the UN SDGs, about IPBES' bleak assessment in 2019 of biodiversity loss). This is also confirmed by significant recent references (Dainese et al. 2019). The different components of agroecology - social movements, sets of practices, and scientific approaches (Altieri 1995; Dalgaard et al. 2003; Gliessman 1997; Wezel et al. 2009)_take in hand this ecological issue which supports ecosystem services. The United Nations (UN) recommend agroecology both as a new approach to development and as a comprehensive alternative to the massive and hazardous use of pesticides, in order to meet the challenges of food rights and human rights (UN (United Nations) 2017). Other concepts have highlighted the importance of promoting ecological processes in agroecosystems while increasing agronomic performance: ecologically intensive agriculture and ecological intensification (Doré et al. 2011; Griffon 2013; Ratnadass and Barzman 2014) and other forms of agriculture using the word "green" in a variety of forms, e.g., "making agriculture green again” (Kuyper and Struik 2014). Today, agroecology provides the main thrust of functional biodiversity to enhance ecological function and the ecosystem services which result from it (Ahmed et al. 2016; Bommarco et al. 2013; Demestihas et al. 2017; Duru et al. 2015; Gaba et al. 2015; Isbell et al. 2017; Petit and Lescourret 2019; Tilman et al. 2006) notably through spatio-temporal diversification of agroecosystems (Duru et al. 2015; Gaba et al. 2015; Malézieux et al. 2009; Ratnadass et al. 212; Tittonell 2014). It is also important that on-farm management action is significant: one can diversify at the extra-field level, but its impacts on-farm are also important and variable (Karp et al. 2018). However, the implementation of these proposals in terms of agricultural practices and the design of agroecological farming systems is still far from being effective in practice, despite investment in research (Simon et al. 2017c), and in the field despite public policies promoting "greener" agriculture (Caron et al. 2014; Wezel et al. 2014). The lack of practical examples of biodiversity at the service of agriculture is no doubt due to uncertainties about the effects of agricultural practices, the ecological processes and the associated ecosystem services (Reid et al. 2005; Thérond et al. 2015; Zhang et al. 2007). 
Today, intensive farming has been shown to have reached its limits. In pest management, questions relating to the questions of sustainability have often been raised (van Lenteren 1998), in particular, the many harmful consequences of the massive use of pesticides: farmers, consumers and society in general face more socio-economic difficulties (Bourguet and Guillemaud 2016; Sheahan et al. 2017); there is mounting pollution of water, soil and the atmosphere (Aubertot et al. 2005; Burdon et al. 2019); biodiversity is being eroded, particularly that of insects (Foucart 2019; Hallmann et al. 2017; Sánchez-Bayo and Wyckhuys 2019) and birds (Chamberlain and Fuller 2000; Hallmann et al. 2014). Researchers are increasingly pointing out the risks and consequences for public health (Baldi et al. 2013; Bassil et al. 2007; Eddleston et al. 2002; Fantke et al. 2012; Hedlund et al. 2020; Hoppin and LePrevost 2017; Robinson et al. 2020; Sheahan et al. 2017; Wyckhuys et al. 2020a); even human rights are mentioned (UN 2017). This really is the breaking point that must bring about change among farmers. Also, to give more weight to this statement, mankind not only pollutes the planet and puts his health in danger, but the polluters themselves run economic losses. This system cannot be sustainable. The 17 Sustainable Development Goals (SDG) adopted in 2015 by the United Nations (https:// sustainabledevelopment.un.org/topics/ sustainabledevelopmentgoals) can be used as a framework to orient research towards sustainable pest management (Dangles and Casas 2019; Struelens and Silvie 2020).

Integrated Pest Management (IPM) is the model of crop protection that has prevailed since its creation in the late 1950s. According to the Food and Agriculture Organization of the United Nations (FAO), "Integrated Pest Management (IPM) means the careful consideration of all available pest control techniques and subsequent integration of appropriate measures that discourage the development of pest populations and keep pesticides and other interventions to levels that are economically justified and reduce or minimize risks to human health and the environment. IPM promotes the growth of a healthy crop with the least possible disruption to agroecosystems and encourages natural pest control mechanisms" (FAO 2020). Initially known as Integrated Control, IPM has, by virtue of its broad principles, contributed to helped improve crop protection around the world. These core principles and guidelines of IPM, as clearly defined back in the 60s (e.g., Bottrell and Bottrell 1979) are the following: i) potentially harmful species will continue to exist at tolerable levels of abundance; ii) the ecosystem is the management unit; iii) use of natural control agents is maximized; iv) any control procedure may produce unexpected and undesirable effects; $v$ ) an interdisciplinary approach is essential. In addition, the main guidelines are as follows: i) analyze the pest status and establish thresholds; ii) devise schemes to lower equilibrium positions; iii) during emergency situations, seek remedial measures that cause minimum ecological disruption; iv) devise monitoring techniques. Finally, the "IPM pyramid" concept provides a reminder that IPM is not only about "integrating pest management technologies" but that there should equally be a hierarchy or prioritization of practices (in which pesticides are listed as a measure of last resort) (Naranjo 2001). In the absence of this prioritization, one can never achieve sustainable pest management and leave everything to chance while causing unacceptable environmental externalities (Pedigo 1989). However, without questioning the merits of the concept (Barzman et al. 2015), and beyond its worthy principles, there are grounds today to question its performance in the field particularly when faced with current and future agricultural challenges.

Several problems are highlighted. Indeed, some authors call into question the relevance of IPM in a sustainable agriculture world. These problems include i) modest reductions or increase in quantities of pesticides used, contrary to the aim of the past 70 years; ii) the swarm of definitions and interpretations of IPM, which mean we no longer know what we are referring to when we talk about IPM; iii) the gap that exists between IPM concepts and practices in the field; iv) the frequent lack of ecological sciences, although they have been the focus for several decades. The objective of this article is to propose a general assessment of IPM. Its concrete implementation in the field is too often still based on the systematic and widespread use of synthetic pesticides. To illustrate the gap between the "virtuous" concept of IPM and unsustainable practices (Pedigo 1995), we have borrowed the phrase "good intentions and hard realities" from Anderson and Feder (2004) that they used in their analysis of agricultural extension. At the end of this review, we propose a change of course in crop protection, in line with the current social, economic, environmental, sanitary, and ecological challenges to tackle in agriculture worldwide.

\section{Sixty years of IPM}

\subsection{Conception and development of IPM}

After the emergence of modern fungicides in the eighteenth century, and herbicides and insecticides in the nineteenth century, research on chemical weapons during the two world wars (in particular on gases) led to the discovery of new organic compounds whose insecticidal properties were then put to use in agriculture. The development of crop protection since the end of the Second World War took place in several stages. Work began in the late 1940s by Californian entomologists, who developed the concept of "supervised control" of crop pests (Smith and Smith 1949). This involved monitoring the population levels of pests in the field, to inform the choice of 


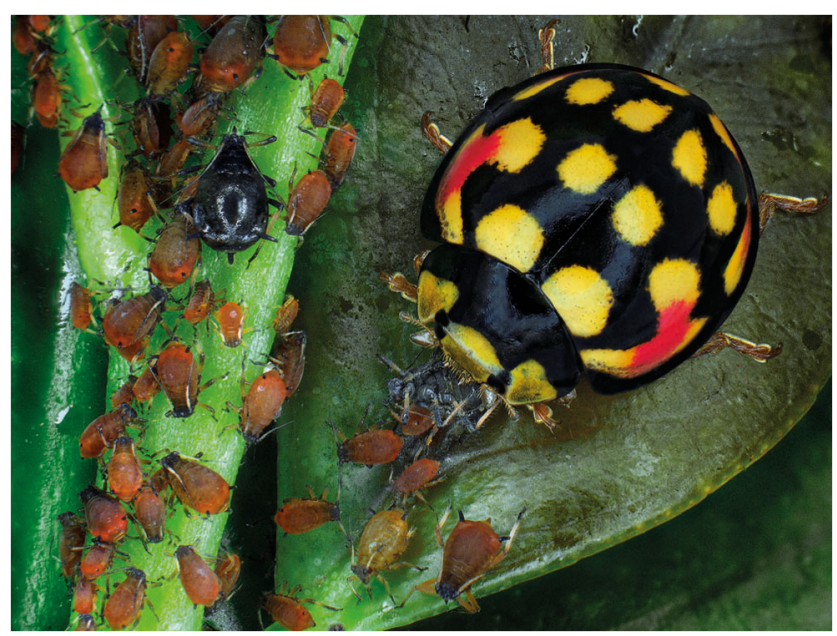

Fig. 1 Biological control: adult of Cheilomenes sulphurea eating aphids in Réunion (France). Photo: (C) Antoine Franck-CIRAD

(essentially chemical) protection methods. At the end of the 1950s in the US, Stern et al. (1959) proposed the concept of Integrated Control, defined as "applied pest control which combines and integrates biological control and chemical control." This concept emphasized the need to take on board environmental concerns and to conciliate biological control (Fig. 1) and chemical control (Fig. 2). This was the time when the general public began to become aware of the harmful effects of pesticides on the environment (Carson 1962) and when the first scientific considerations were given to integrating biological control and chemical control (van den Bosch and Stern 1962), and these studies have continued since.

In the 1940s and 1950s, the overuse of pesticides, both in terms of treatment frequency and in the doses of active ingredients applied, led to ecological disasters and the impossibility of controlling pest populations due to build-up of pesticide resistance. Such situations have been encountered, for example, in Latin America (Wille 1951). In Peru's Canette valley,

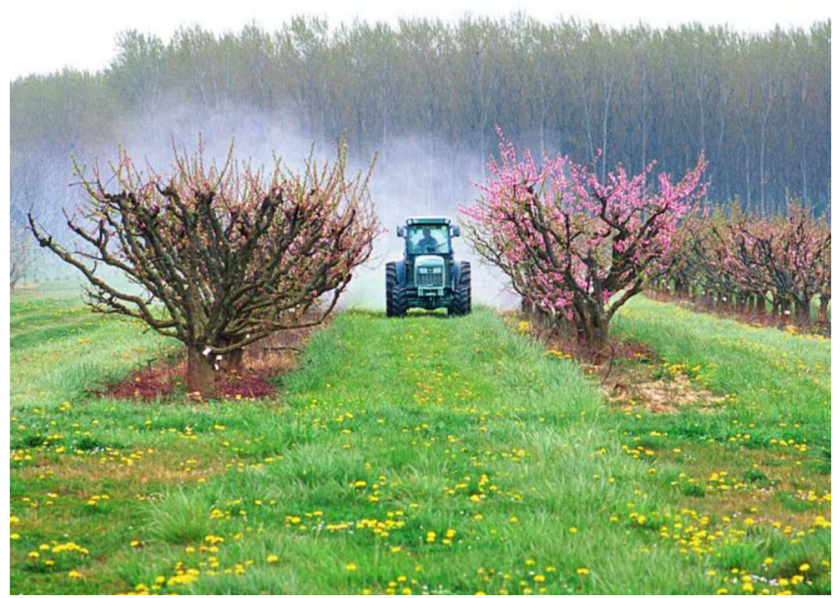

Fig. 2 Chemical control: insecticide treatment in a peach orchard in South of France. Photo: (C) Christophe Maitre-INRAE in 1956, it had become practically impossible to control outbreaks of cotton pests despite repeated applications (15 to 25 per season). In Central America (El Salvador, Nicaragua), 30 to 50 treatments in 90 days were recorded (Barducci 1972; Deguine et al. 2008). In these desperate situations, IPM has emerged as a suitable and recommended crop protection strategy. However, this did not last.

In the 1960s, pest management was concerned with managing populations of pests in a crop. In the 1970s, especially in continental Europe, the FAO and the IOBC (International Organization for Biological and integrated Control of noxious animals and plants) promoted Integrated Pest Management. For the FAO, Smith and Reynolds (1966) defined IPM as "a pest population management system that utilizes all suitable techniques in a compatible manner to reduce pest populations and maintain them at levels below those causing economic injury." Currently, the FAO definition relies on these techniques and provides a broader view on the health of agroecosystems. The IOBC defined Integrated Pest Management in 1973 as "a pest control system that uses a set of methods that satisfy economic, ecological and toxicological requirements by giving priority to natural control and by respecting tolerance thresholds" (Ferron 1999). The concept of IPM, for English speakers, Manejo Integrado de Plagas for Spanish speakers and Protection Intégrée des Cultures for French speakers (Lucas 2007), has since become a benchmark in crop protection around the world. Note that the first two translations are pest-oriented while the latter is crop-oriented.

In the early 1990s, the IOBC and the LEAF (Linking Agriculture and Farming) Group proposed extending the principles and objectives of IPM to integrated production, respectively under the names Integrated Farming (El Titi et al. 1993) and Integrated Crop Management (Leake 2000). This implies that crop protection should not be disconnected from other objectives expected from agroecosystems. In integrated production, preservation of resources (soil, water, energy, and labor) is associated with limiting pest damage and increasing agronomic performance (quantity and quality of agricultural production) (Boller et al. 2004). However, the term "Integrated Production" has been overused. In fact, it has been used to describe so-called "virtuous" production or agricultural practices, even if it sometimes departs significantly from the IOBC directives, and occasionally from its concept and spirit. This is particularly the case for Integrated Fruit Production in France with regard to environmental issues (Bellon et al. 2006). In addition, anxious that the term "integrated production" might be badly received by the French agricultural profession due to possible confusion with economic integration, the FARRE network (Forum of Farmers Responsible and Respectful of the Environment) chose to translate the English term Integrated Farm Management (within the framework of the European Integrated Farming Initiative) into 
Agriculture Raisonnée [close to responsible agriculture (Goss and Barry 1995)], which suffers from the same semantic issues as IPM (Bonny 1997; Lucas et al. 2017). It is therefore ultimately only in Switzerland, the Czech Republic, and Northern Italy that Integrated Production has been developed (and there solely in fruit production), as well as in Reunion (France), e.g., Integrated Mango Production (Vincenot and Normand 2009).

This example illustrates the semantics of the various concepts of IPM, in particular their translation to French and other languages (mostly European and American, the continents where these concepts appeared). In addition to the ambiguity of the term "integrated" (vs. "harmonized," even the notion of economic integration) is the meaning of the term "management" (vs. "control"), and "pest" [vs. bioagressors(s), disease(s)]. For example, IPM has long been translated in French as Lutte Intégrée, an almost literal translation of "Integrated Control," but the term adopted by consensus is now Protection Intégrée des Cultures (Integrated Crop Protection) (Ferron 1999). In German and Dutch, the notion of "control" is advanced (integrierte Schädlingsbekämpfung and Geïntegreerde bestrijding) (Wildbolz 1962), while in Spanish, besides "control," it resembles the English in that "management" is stressed (Manejo integrado de plagas) (Nilda and Vázquez 2004). This reflects differences in orientation ("pest": single pest or set of pests; "crop": single crop vs. cropping system vs. agroecosystem vs. production system).

\subsection{A quasi-infinite number of definitions and interpretations}

A lot has been written about IPM, but capturing all the different interpretations is not the purpose of this review. Instead, we refer the reader to the following noteworthy publications or reference works: Abrol 2014; Abrol and Shankar 2012; Dent 1995; Ehler 2006; Ferron 1999; Heinrichs et al. 2009; Kogan 1998; Kogan and Heinrichs 2020; Koul et al. 2004; Maredia et al. 2003; Norris et al. 2003; Peshin and Dhawan 2009; Prokopy and Kogan 2003; Radcliffe et al. 2009; Rapisarda and Cocuzza 2018; Smith and van den Bosch 1967; Wearing 1988; Wyckhuys et al. 2021).

Over the years, IPM has seen its definitions multiply to the point where Bajwa and Kogan (2002) identified 67 between 1959 and 2000. Coll and Wajnberg (2017b) give a choice of 42 definitions, based in part on the Bajwa and Kogan (2002) list, spanning the period 1959-2016, reflecting the diversity of elements, concepts, and criteria. It is likely that there are more than a hundred definitions of IPM today.

For a three-word concept, there are as many definitions as there are authors and for each definition that emphasizes one particular feature of IPM, another can be found contradicting it (Jeger 2000). This has led to confusion and to highly inconsistent levels of implementation in the field (Lucas et al. 2017; Stetkiewicz et al. 2018).

It is therefore pretentious to offer a single definition of IPM. Further to Bajwa and Kogan (2002) and Coll and Wajnberg (2017b), Stenberg (2017) considers that IPM is: “a holistic 'approach' or 'strategy' to combat plant pests and diseases using all available methods, while minimizing applications of chemical pesticides." "Approach" refers to the scientific and conceptual approach and "strategy" to its implementation in the field, depending on the definition of IPM used or levels of practice complexity [e.g., the four levels of IPM according to Prokopy 1994], adoption of IPM ranges from 0 to $100 \%$ (Shennan et al. 2001).

It is difficult to find characteristics common to all definitions of IPM. However, we offer some of them below. IPM's primary aim is to integrate the different pest management techniques (regular cropping practices along with genetic, physical, biological, and chemical means). It also promotes socio-economic viability and a reduction in use of chemical pesticides, especially after 1962 and the publication of Carson (1962), to minimize the risks to the environment and public health. IPM also aims to make these techniques (notably chemical and biological) compatible and synergistic. This highlights the need for multidisciplinary and interdisciplinary research on different techniques and their interactions. Finally, the use of chemical pesticides is authorized only as a last resort and, if necessary, based on intervention thresholds, part of the guidelines of IPM and implied in the universally accepted FAO definition. The first and stated last characteristics we mentioned were also identified by Hurley and Sun (2019) as two key elements frequently found in definitions.

Coll and Wajnberg (2017b) point out that the definitions fail to mention that integration relates to all the pests of a particular crop (phyto-pathogenic microorganisms, arthropod pests, phyto-pathogenic/pest nematodes, weeds/parasitic plants). For them, integration is about controlling a single or a small number of pest species. This is sometimes called "vertical integration," as opposed to "horizontal integration" which entails simultaneous management of several pest classes (Aubertot et al. 2005; Ehler 2006; Lamichhane et al. 2017; Weiss et al. 2009). Finally, Young (2017) calls attention to the fact that insects are the most studied type of pests in IPM (75\% of publications, based on a meta-analysis of the last 40 years).

\section{IPM roadblocks and adoption barriers}

During its 60-year history, clear successes have been achieved in IPM implementation in both Western nations and in the Southern hemisphere, involving concrete reductions in pesticide use, altered farming patterns and wide-ranging socio-economic benefits (Norton and Mullen 1994; Pretty 2005; Pretty and Bharucha 2015). In Southeast Asia, farmer training 
programs attained a staggering $92 \%$ pesticide reduction in rice (Bangladesh) or $50-70 \%$ reduction in tea and cabbage (Vietnam) (van den Berg 2004). In addition, the International Rice Research Institute (IRRI) attained 50$80 \%$ cuts in insecticide use on millions of rice farms without any noticeable yield loss (Bottrell and Schoenly 2012). In the US, the Huffaker project for IPM and the IPM consortium (1972-1985) attained a 70-80\% reduction of a wide set of pesticides on $>5$ million hectares - resulting in more than $\$ 500$ million annual savings (Pimentel and Peshin 2014). In a review of more than 500 IPM programs from across the globe, $13 \%$ and $19 \%$ respective increases in crop yields and farm profits were logged (Waddington and White 2014) with even partial IPM adoption delivering concrete benefits (Norton et al. 2019). Irrespective of possible difficulties in impact assessment (Puente et al. 2011; Rejesus and Jones 2020), IPM has certainly had a positive impact on farmer livelihoods and environmental integrity.

Particularly in the Southern hemisphere, millions of smallholder farmers successfully adopted IPM (Hammig et al. 2008; Ngin et al. 2017; Pretty 2005; Rejesus et al. 2009), though these achievements were routinely undone following program termination, political change, altered priorities, or agroindustry meddling (Pretty 2005; Thorburn 2015; Wilson and Tisdell 2001). Also, several (top-down) IPM programs failed to account for local agroecological or socio-economic contexts (Ruesink 1980; Smith 1983; Uneke 2007). Participatory training programs such as the UN-endorsed Farmer Field Schools (IPM-FFS) were criticized for their prohibitive cost, needs in personnel requirements and insufficient scalability (Rajotte et al. 2005; Tripp et al. 2005; van den Berg and Jiggins 2007; Waddington and White 2014; Waddington et al. 2014). However, the FAO Farmer Field Schools program has covered millions of farmers across Southeast Asia, and average reductions of $70-75 \%$ in pesticide use were attained (with reductions in some districts in Indonesia of up to $99 \%$ ). Yet, once supportive policies and funding were removed, pesticide use surged again (Bottrell and Schoenly 2012; Heong and Escalada 1997; Thorburn 2014 and 2015).

More than half a century after its conception, IPM has not been adopted to a satisfactory extent and has largely failed to deliver on its promise (Bottrell 1996; Corbet 1981; Ehler 2006; Ehler and Bottrell 2000; Orr 2003; Pimentel 1982; Sherman and Gent 2014; van den Bosch 1965; Willey
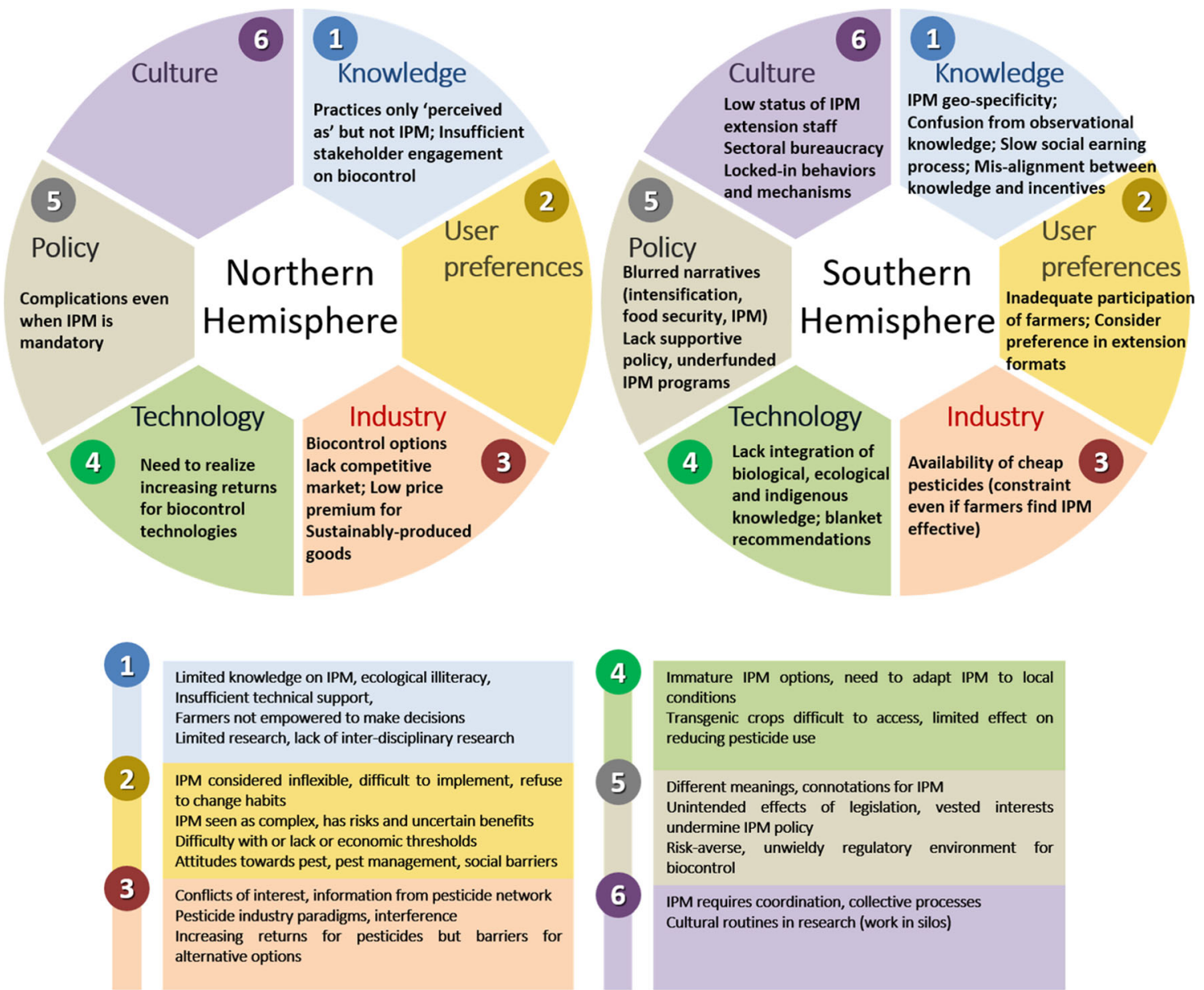

Fig. 3 Barriers to adoption and spread of IPM in the Northern and Southern hemispheres, categorized under six pillars of sustainability transition (Template design by Showeet.com) 
1978). The low levels of farmer adoption and insufficient IPM technology diffusion are invariably ascribed to different factors, some of which closely related to local farming contexts.

We summarize reasons for low adoption and spread of IPM in both the Northern and Southern hemispheres (Fig. 3). While certain factors apply across innovations (Juma 2016), others are inherent to crop protection or the broader agriculture sector. In the following paragraphs, we examine each of these IPM roadblocks through a lens of sustainability transitions, which help in understanding social, technical, institutional and ecological aspects of shifts towards sustainability (Loorbach et al. 2017).

\subsection{Weak farmer knowledge base}

"What farmers don't know can't help them," so wrote the anthropologist Jeffery Bentley when outlining farmers' technical knowledge regarding plant health (Bentley 1989). A key factor hampering uptake of (knowledge-intensive) IPM is farmers' deficient ecological literacy and incomplete understanding of its constituent processes (Horgan 2017; Murray et al. 2021; Rajotte et al. 2005; van Mele 2008; Wyckhuys et al. 2019a). This particular barrier applies across countries and farming contexts, comprises technical aspects and basic ecological concepts, and manifests as an undervaluation of certain IPM components (Zhang et al. 2018). For example, while the active conservation or in-field augmentation of beneficial organisms is an important IPM technology, many farmers are totally unaware of the existence of biological control agents such as parasitic wasps, predaceous mites or insectkilling nematodes (Wyckhuys et al. 2019a). In early attempts to promote IPM, e.g., through training \& visit (T\&V) extension schemes or other top-down technology transfer initiatives, farmers were indeed insufficiently empowered to make decisions based on such ecological information. Yet, participatory training efforts such as FFS included "hands-on" experiential learning modules and effectively removed this constraint (van de Fliert 1993; van Schoubroeck 1999).

FFS experiences also revealed a need for farmers to be sufficiently involved in IPM development, from design up till in-field validation (Andrews et al. 1992; Geertsema et al. 2016; Morse 2009; van Huis and Meerman 1997; Way and van Emden 2000). Collaborative FFS facilitate changes in farmers' practices and trajectories compared to consultative FFS (Bakker et al. 2021). Participatory research and twoway dialogues between scientists, extension officers, and experts are of critical importance (Bentley et al. 2003; Deguine and Ratnadass 2017). Building these elements into extension programs helps blend practical experience with scientific insights, thus filling knowledge gaps and circumventing the disciplinary silos that pervade in academia (Feder et al. 2004; Untung 1995; van Huis and Meerman 1997). Moreover, the communication tools delivering IPM information can also be used to deliver pesticide information (CAVAC 2014; Flor et al. 2018). IPM practitioners still need to critically examine how these tools, especially digital media, will disseminate IPM practices. Moreover, there is only limited uptake in the use of communication tools in certain cultural and linguistic contexts. Experiences vary from country to country. The benefits of participatory extension have primarily been reaped in the Southern Hemisphere, where (often illiterate) smallholder farmers operate in heterogeneous farm settings and thus have diverse needs (Alwang et al. 2019; Morse and Buhler 1997). Group-based learning processes, e.g., as promoted through FFS take time and the ensuing innovation tends to proceed at a slow pace (Rebaudo and Dangles 2011), but ongoing experimentation by individual farmers can yield valuable, locally adapted technologies (van Mele et al. 2005). Rebaudo et al. (2014) suggest that "new approaches in pest management extension practices should include topics such as group decision making, intergroup relations, commitment, and persuasion which deal directly with how other farmers influence each other's thoughts and actions." On the other hand, in the Northern Hemisphere, there appears to be much confusion among farmers regarding whether certain technologies are IPM-compatible or not (Stetkiewicz et al. 2018). Moreover, farmers are targeted in communications about biological control, but there is less engagement of other types of stakeholders such as policymakers (Barratt et al. 2018).

\subsection{User preferences and risk aversion}

End-users' perceptions are a key obstacle to IPM diffusion, and several IPM constituent technologies are perceived as inflexible, difficult to implement and incompatible with (deeply engrained) farming habits (Cowan and Gunby 1996; Parsa et al. 2014). IPM implementation can easily be perceived as risky considering how its benefits in terms of technological reliability, sustained yield or enhanced profit, are often unclear to farmers (Fernandez-Cornejo and Kackmeister 1996; Jørs et al. 2017; Lefebvre et al. 2015; Marrone 2009). Social and psychological elements (e.g., prevailing beliefs or attitudes; Morales and Perfecto 2000; Wyckhuys et al. 2019a) further tilt the balance in favor of risk-averse practices such as preventive use of agrochemicals (Despotović et al. 2019; Munyua 2003; Vasileiadis 2017). Also, many farmers place disproportionate emphasis on potential pest-induced losses or the relative role of crop protection within overall farm management (Heong and Escalada 1997; Ohmart 2008; Palis 2006), while they are far less clear about the "insurance" benefits provided by, for example, insect biodiversity (Lamarque et al. 2014). As such, the ensuing decision-making is guided by "worst case" scenarios and further reinforced by marketing campaigns of agrochemical suppliers (Heong and Escalada 1999). Yet, such misconceptions can easily be mitigated by 
relatively cheap, small-scale experiments, e.g., within FFS programs (Heong and Escalda 1999).

In both the Northern and Southern hemispheres, a key hurdle is the overall absence (or insufficient farmer awareness) of IPM decision thresholds for particular crops and the convoluted monitoring schemes that are required to assess on-farm pest pressure (Murray et al. 2021; Ohmart 2008; Sivapragasam 2004). Often, the cumbersome nature of threshold-based IPM decision-making leads farmers to confuse different management concepts or to favor more user-friendly options and convenient application methods, e.g., insecticide-coated seeds, calendar-based sprays (Horgan 2017; Möhring et al. 2020). Conversely, straightforward messaging, simple decision rules and heuristics such as "no early spray" or "3 reductions, 3 gains" can help steer farmers towards more environmentally friendly crop protection schemes (Heong and Escalada 1997; Huan et al. 2005). Other constraints that apply primarily to the Southern hemisphere include inadequate meaningful participation and a lack of consideration for the ultimate needs and preferences of end-users (Iqbal 2010; Samiee et al. 2009).

\subsection{Vested interests and corporate responsibility}

The adoption of IPM is shaped by extensive lobbying, marketing, and wide-ranging manipulation by the agrochemical industry (Goulson 2020). Across the globe, IPM technologies struggle to find fertile ground and flourish in settings where farm advisers are paid (or decision-support tools are designed) by this industry, where farmers annually draw loans from chemical suppliers, or where the only accessible source of pest management information is to be found behind the counter of the pesticide shop (Ehler 2006; Flor et al. 2020; Wagner et al. 2016; Wyckhuys and O'Neil 2007). Biased information about IPM and pesticide safety thus abounds while the only behavior change that is fervently pursued is the one leading to sustained or enhanced company profits (Murray and Taylor 2000). There are now innumerable accounts of direct and covert interference by agrochemical companies and concerted efforts to sustain IPM beliefs that are aligned with their business plans (Goulson 2020; Hutchins 1995; Murray and Taylor 2000; Pretty and Bharucha 2015; Untung 1995; van den Bosch 1989). In the meantime, alternative IPM products face diverse bureaucratic barriers to proper registration and farmer access (Barratt et al. 2018; Cowan and Gunby 1996; Vanloqueren and Baret 2009).

The above trends are sustained by schemes that support pesticide subsidies and which create confusion (Parsa et al. 2014). None of the above is unique to the present-day pesticide problem, but are typical features of the struggle by producers of incumbent technologies (i.e., synthetic pesticides) to maintain a "status quo" when faced with the emergence of potentially "disruptive" innovations such as biological control, agroecology, or robotic weeding (Juma 2016). Indeed, today's agrochemical industry is walking along several of the well-trodden paths that, for example, the Horse Association of America chose when resisting farm mechanization during the 1920s.

Though the agrochemical industry is omnipresent in both hemispheres, the rudimentary registration processes in several developing countries have led to high pesticide loads, a continued use of banned and restricted-use substances and a lack of water-tight regulation (Wesseling 2005). In settings with resource-poor smallholders, subsistence farming systems, no organic certification schemes, or lagging demand for highvalue commodities, the availability of cheap pesticides hinders adoption of IPM (Orr 2003; Pretty and Bharucha 2015). Conversely, in areas where consumers are willing to pay a premium price for pesticide-free produce or where nonchemical alternatives are widely available (e.g., biological control in Europe's greenhouse sector; van Lenteren 2012) certain IPM barriers can be removed (Lefebvre et al. 2015; Marrone 2009; Onillon and Gullino 1999). In either case, for innovation and eventual "creative destruction" to proceed (Juma 2016), there are clear and outspoken vested interests and very few signs that the agrochemical industry is committed to regulate itself and take responsibility for its actions (Goulson 2020). A sign of hope is that comprehensive policy frameworks are emerging, e.g., the EU Farm-to-Fork program that will help the agrochemical industry prioritize environmental health instead of limitless profit (European Commission 2020).

\subsection{Traditional practices and emerging IPM technologies}

Despite the decades of committed basic and applied research that have gone into developing and validating its constituent technologies, insufficient implementation of IPM advances have been made for a number of crops in the Southern hemisphere (Cowan and Gunby 1996; Goodell 1984; Rajotte et al. 2005; Uneke 2007; Way and van Emden 2000; Wyckhuys et al. 2013). Also, the decades-long research on nonchemical crop protection has not resulted in changes in farmer behavior or in tangible socio-ecological outcomes in either hemisphere (González-Chang et al. 2020). On the other hand, much can be learned from centuries of experience of traditional farmers and the wealth of preventative, agroecological practices that are already in place in a myriad of cropping systems (Altieri 2004). For most broad-acre crops, there is currently a range of effective, locally validated IPM alternatives including biological control, decision-support tools, innovative pesticide delivery modes (e.g., attract-and-kill) or agronomic measures such as diversified crop sequences, implementation of covercrops, and inter-cropping (Veres et al. 2020). For example, in $78 \%$ of the authorized usage cases for neonicotinoid 
insecticides in France, at least one non-chemical alternative method can immediately replace chemical compounds (Jactel et al. 2019). A global analysis recently demonstrated how IPM technologies such as biological control can alleviate the food safety and environmental health hazards linked to neonicotinoid insecticides (Wyckhuys et al. 2020a). The technological progress and implementation readiness of various biological control and biopesticide approaches bodes well for ongoing efforts to phase out these compounds in a range of fruit and vegetable crops in Europe and North America. Genetically engineered crops producing Bacillus thuringiensis $(\mathrm{Bt})$ endotoxins and host-plant resistance also fit under the IPM umbrella and have ample potential to reduce pesticide use, though the former technology does carry certain risks (Bharucha 2015; Peshin and Zhang 2014; Romeis et al. 2019). In recent years, the rise in artificial intelligence, remote sensing, and autonomous agricultural vehicles (e.g., solarpowered mechanical weeding robots) has created golden opportunities for a sharp reduction, or even outright suspension, of pesticide use (Filho et al. 2020). Notwithstanding the rapid technological advances and IPM innovations, one should ensure that smallholder farmers in the Southern hemisphere are not bypassed, that context-specific solutions are offered and that a full integration of indigenous ecological knowledge is pursued (Abate et al. 2000; Nampeera et al. 2019; van Huis and Meerman 1997).

\subsection{Hard and soft policy levers}

Effectively influencing farmer behavior is difficult (Kanter et al. 2019). However, to ease this process, different "pressure points" can be identified to drive along agri-food value chains and both soft (i.e., certification schemes, food safety labelling) and hard policy options (i.e., conditional financial assistance) can be considered. Still, IPM-related policies are faced with three common constraints. First, diverging IPM definitions and connotations complicate the formulation and interpretation of clear policies (Ehler 2005; Ehler and Bottrell 2000; Hoy 2020; Jeger 2000; Ohmart 2008; Untung 1995). Second, where IPM is codified into legislation, there are unintended effects and vested interests which move towards an improvement in pesticide efficiency (Matyjaszczyk 2019; Rola and Pingali 1993; Trumble 1998). Third, a risk-averse policy environment exists around some IPM solutions with, for example, disproportionate attention given to the eventual non-target risk of ecologically based alternatives such as biological control (Barratt et al. 2018; van Wilgen et al. 2013). These concerns are often translated into overly stringent regulatory processes that tend to obscure positive benefits and prevent the timely implementation of and farmer access to science-based solutions, which are primarily aimed at alleviating the well-documented adverse ecological impact of conventional control practices.
In countries or geopolitical entities where IPM has been made mandatory (e.g., the EU), the operationalization, monitoring, and expectations for immediate conversion limited the effectiveness of IPM-based policies (Barzman et al. 2015; Matyjaszczyk 2019). There are cases where sustainability and IPM are explicit in policy, but these become blurred by notions of food security or intensification that ultimately again legitimize reliance on pesticides (Flor et al. 2018; Untung 1995). Furthermore, there are cases of delayed policies that hamper IPM adoption: underfinanced extension systems that provide inadequate support to farmers in pest diagnosis and IPM implementation (Pretty and Bharucha 2015; Rola and Pingali 1993). In the Northern hemisphere, knowledgedeficit interventions and policy mismatches lead to an ineffective response to the pressing needs of some novice farmers, farm incubators, and small-scale marketing innovators where locally validated IPM represents a desirable technological advantage (Calo 2018).

\subsection{Cultural barriers and the decline of public interest science}

For decades, systems-approaches have been advocated to advance the development and implementation of IPM, while integrated multi-stakeholder, multi-level projects are increasingly seen as vital to attain measurable change at scale (Altieri et al. 1983; Lewis et al. 1997; Rodenburg et al. 2015; Schut et al. 2014). Yet, the bulk of IPM scientists continue to operate in silos, adopt a pest-centric perspective, exhibit increasing 'niche' specialization and tend to focus on their "mandatory" crop and/or pest system (Alwang et al. 2019; Coll and Wajnberg 2017b; Ehler 2006; Morse and Buhler 1997; Rosenheim and Coll 2008; Vanloqueren and Baret 2009; Warner et al. 2011). Also, reaching out across disciplinary boundaries is still an unusual act: even though economic ornithology experienced a bonanza during the late nineteenth century (Kronenberg 2014), only scant attention is now paid to valuing the contribution of bird- or insect-mediated biological control to IPM (Garcia et al. 2020; Naranjo et al. 2015). Another aspect that is routinely forgotten is how IPM can entail collective decision-making, coordination, or shared norms and values; these are not automatically generated in communities (Castella et al. 1999; Cowan and Gunby 1996; Palis 2006; Parsa et al. 2014; Rebaudo et al. 2014). Yet, a perceived need for collective decision-making in certain farming systems should not preclude a push for behavioral change at the individual level. Indeed, when addressing highly mobile polyphagous pests or noxious weeds, land-use or pest management decisions of just a handful of farmers can bring about often dramatic positive change at the agrolandscape level (Bagavathiannan et al. 2019; Vreysen et al. 2007). Also, even when only a fraction of farmers within a given community is trained on IPM, this information invariably gets put into 
practice, triggers further innovation, and disseminates filters through existing social networks (Rebaudo and Dangles 2013; Wyckhuys and O'Neil 2007).

In the Southern hemisphere, government extension agents and crop advisors unaffiliated with the pesticide industry are seen to have low status because of their comparatively limited operational funds (Teoh and Ooi 1986). For many of these actors, sectoral bureaucracies further impede their work (Untung 1995). These are part of the human or institutional mechanisms that keep pesticide use locked into pest management routines (Spangenberg et al. 2015). Finally, the institutional reconfiguration of universities and the accompanying decline in public interest science should be of concern to all (Warner et al. 2011). Since its heydays in the 1960s, biological control science (as a key constituent of IPM) has been removed from core curricula in the University of California (UC) system while favouring more "fancy," prestigious disciplines such as transgenic engineering. Conversely, many countries in the Southern hemisphere continue to lag behind their northern counterparts in building the necessary institutional capacity on public interest science domains that underpin IPM and agroecology.

\section{Inconsistencies between concepts and practices in IPM}

\subsection{Integration or juxtaposition of practices?}

IPM has often been considered a sphere of integration (de facto by the words that make up its name). Prokopy (1994) and Kogan (1998) defined 3 levels of integration in IPM: an initial level of single pest management techniques, a second level of strategies for the management of a group of pests and a third level of integration of management techniques for populations of several pests as part of the overall strategy of agronomic management of cropping systems. Figure 4 presents an ideal situation of integrated protection in an apple orchard.
This theoretical range of integration has rarely been tested in the field. In reality, IPM has often been a juxtaposition of different crop protection techniques (Ehler 2005; Lucas et al. 2017; Stenberg 2017). Frison et al. (1999) confirms that integration at several levels (i.e., control of a single pest on a particular crop; control of several pests on the same crop; several crops; several farms) is not common. This lack of integration means that practices "superimposed" on each other do not result in any synergy and are not optimized (Ehler 2006; Hoy 2020). They are sometimes incompatible, or barely compatible with each other (Reteau 2017; Suckling et al. 2014), with instances of synergy occurring by pure chance. In the goal of demonstrating that this integration is not obvious in practice, Ohmart (2009) draws a clear distinction between two areas of IPM: on the one hand, the academic sphere, research and knowledge, and on the other, the field and production area. Long before him, Hutchins (1995) distinguished an "idealistic IPM" of theory and a "realistic IPM" for farmers. There is little interaction between these two spheres: reasons include farmers' ignorance of the science behind the techniques; there is a confusion of principles due to different definitions; insufficient consideration of ecological issues in research; insufficient links between researchers and practitioners (Deguine and Ratnadass 2017). In addition, there is a deficit in the roll-out of incentives which are clearly necessary to encourage farmers to adopt IPM, for example at the European level where it is compulsory (Lefebvre et al. 2015).

The search to coordinate chemical and biological control in the 1950s was the driving force behind Integrated Control, the forerunner to IPM, and the conditions for integration were quickly reviewed (van den Bosch and Stern 1962). Today, however, their compatibility is widely questioned (Ehler and Bottrell 2000; Lucas et al. 2017; Stenberg 2017; Suckling et al. 2012). Analysis of the history of research and crop protection practices shows that chemical and biological control have undergone concomitant and continuous changes, but most often, these changes have been concomitant and
Fig. 4 Integrating different methods to achieve pome fruit protection against pests, diseases, and weeds (adapted from Simon et al. (2017a))

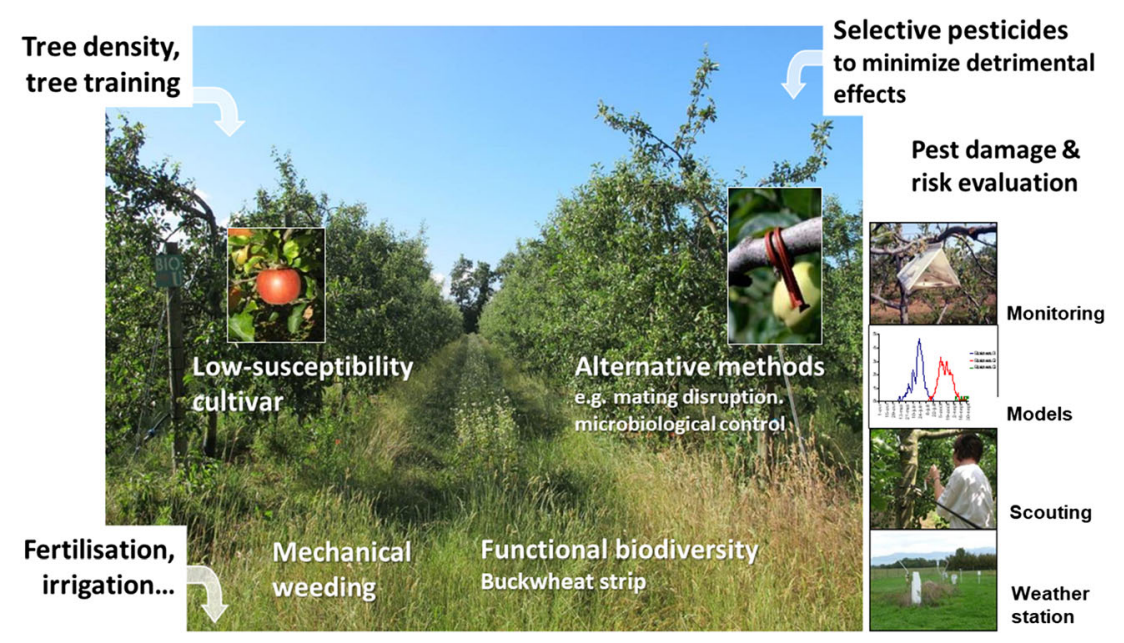



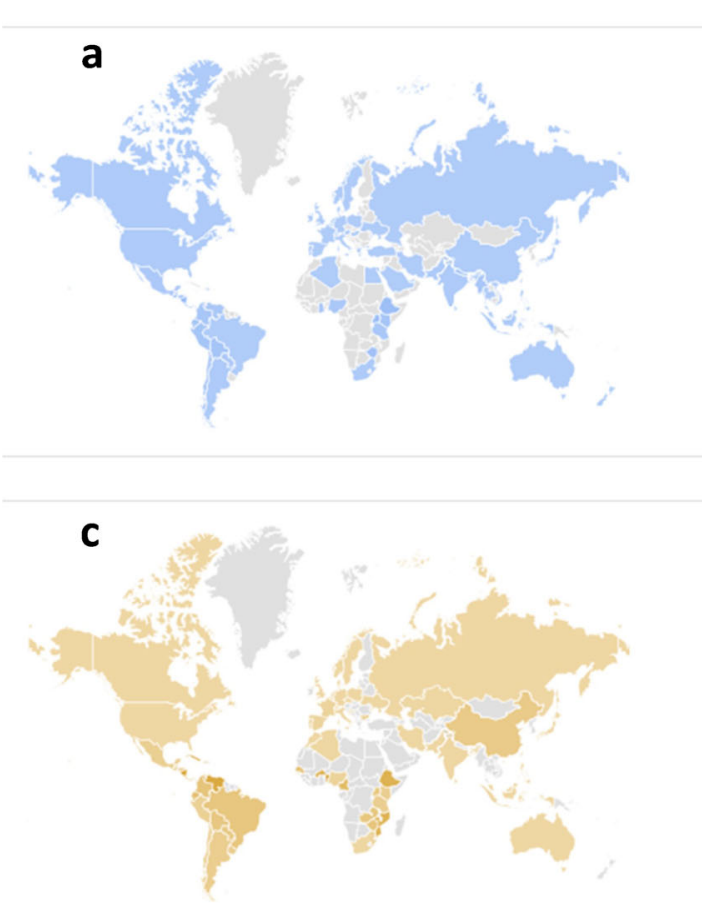

Fig. 5 Geographical representation of public interest in different pest management topics at a global and country-specific level. Online public interest (or so-called salience; Wyckhuys et al. 2019b) was assessed over 2004-2020 by running Google Trends queries for different search terms. More specifically, searches were performed for "Integrated Pest Management" (a), "Biological Pest Control" (b), "Agroecology" (c), and

independent from one another (Reteau 2017). Figure 5 suggests that one can simply indicate how scientific and public interest in different types of pest management strategies differs widely, with rapidly emerging attention. Examples of this are biological control in the Andes region (particularly Colombia) and eastern Africa, biopesticides in China, Western Europe and India, or agroecology in a number of countries in Africa and Latin America. In addition, Perrin (1997) suggests that both chemical and biological approaches have resulted in better cooperation between public and private sectors and are both considered as possible solutions. In the
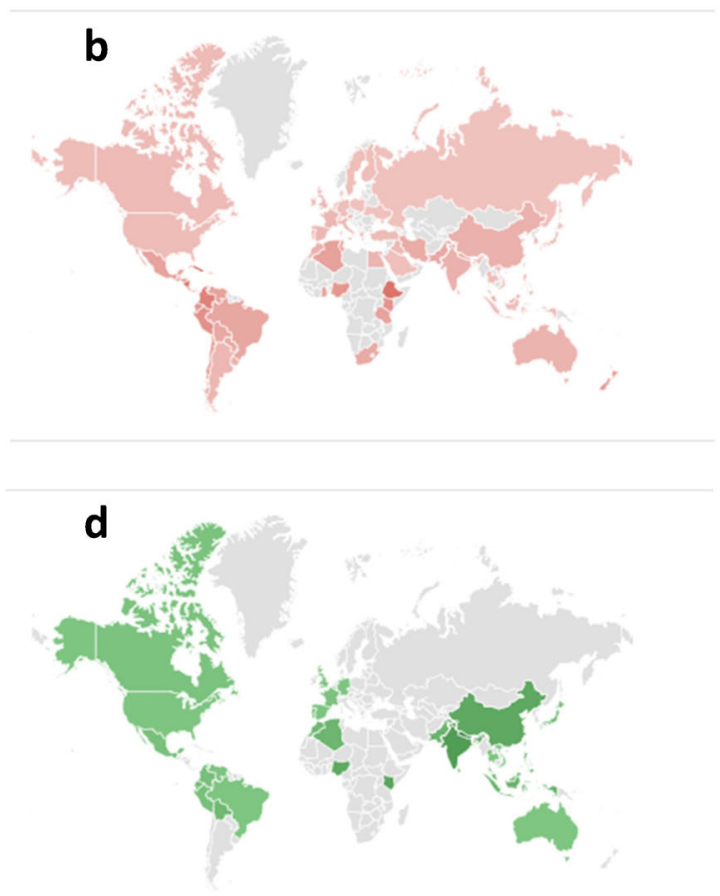

"Biopesticide" (d). Within a given map, darker colors reflect a higher proportion of internet queries for a given search term relative to the total number of internet searches in that country over the 16-year time period. Gray represents insufficient data. All maps are drawn based on non-backcorrected outputs. Google Trends queries can be run on https://trends.google. com

rare instances where these forms of control were used concurrently, there was a lack of clear planning and of a strategy regarding levels of intensity; results were disappointing, underlining their incompatibility (De Bach 1974; Deguine and Ratnadass 2017).

In addition to Fig. 5, a research on Google Books Ngram Viewer shows the temporal evolution of several terms, including "Integrated Pest Management" and "Agroecology" (Fig. 6). There has been a steady decline of IPM in books since the mid-1990s and an increase in Agroecology since the early 2000s. These curves suggest that the application of
Fig. 6 Frequencies (yearly counts, normalized to the maximum counts for the term "Integrated Pest Management") of four key terms - Integrated Pest Management, Agroecology, Biopesticide, and Biological Pest Control- found in sources printed between 1960 and 2019. Analysis performed on https:// books.google.com/ngrams on March 12, 2021

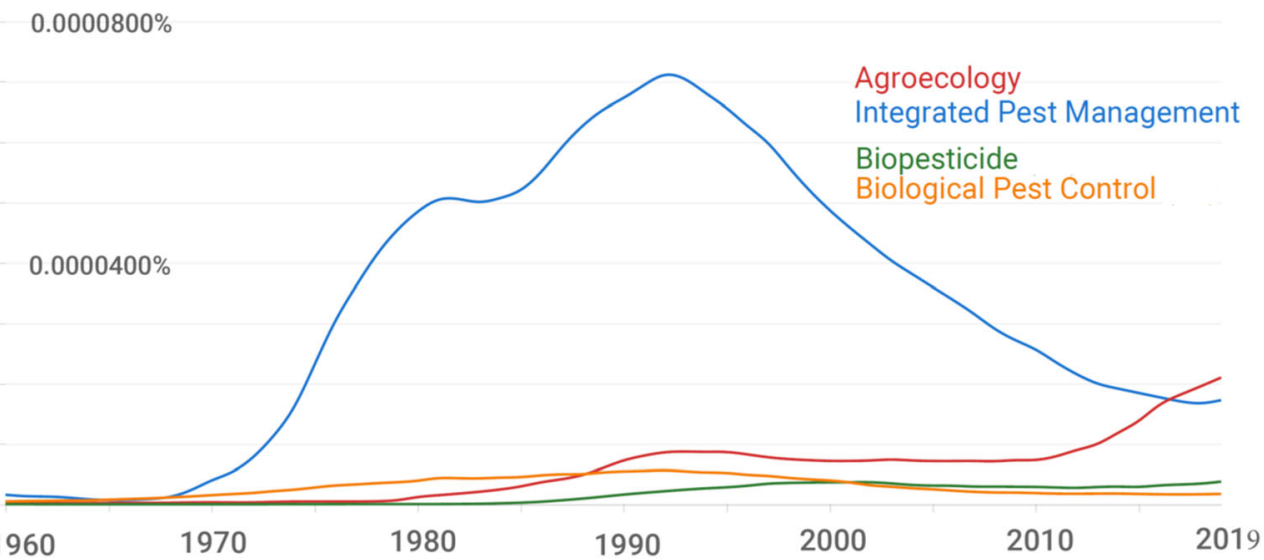


agroecology to crop protection (Agroecological Crop Protection, see Section 7) is underway and that a paradigm shift, at least in the books, is taking place. This paradigm shift is probably an abandonment of the pest "enemies/allies" concept, shifting towards a vision based on Sustainable Development Goals (SDG) (Dangles and Crespo-Pérez 2020). It is noticeable that biological control remains a narrow area of publication, but it is perfectly compatible with agroecology.

It is important to draw attention to the fact that despite the strict guidelines and rules of IPM and the clear need for a hierarchy different technologies, as identified in the late 1960s/early 1970s and described in the IPM pyramid (Naranjo 2001), this has been diluted. Thus, when IPM was first developed, there was no room for subjective assessments and differing interpretations - as to fit individual companies' business plans. As indicated by Pedigo (1989): "In order to integrate several tactics into the overall pest management program, a set of principles is needed as a guide. Without principles, integration may proceed along some serendipitous routes - which is usually ineffective and generally unacceptable." In pepper and tomato production in greenhouses, Dáder et al. (2020) insist that the combination of biological and chemical control requires a schedule in their implementation and a good knowledge of the interactions: early establishment of beneficials, then chemical control, with or without compatibility depending on the beneficials and the molecules. Hokkanen (2015) considers that today there is a significant gap between the traditional principles of IPM, which are described in the IPM pyramid, and the current situation. The use of chemical pesticides, which was supposed to represent only a small part of this pyramid, represents the majority of cases, which can result in an upside down pyramid. For Hokkanen (2015), "it becomes obvious that this method of pest management will neither be stable nor sustainable."

It has also long been noted that there is no proposed strategy for the implementation of practices in the field. It will have taken more than half a century since the advent of IPM for a sequential logic to be proposed for IPM implementation in the European Union (Barzman et al. 2015). While these authors suggest using chemical control as a last resort, after exhausting all other techniques (i.e., biological control, cultural control, physical control, varietal control), chemical control as a first resort is still commonplace and still observed in the field in the vast majority of farms not only in Europe, but also around the world (Lucas et al. 2017).

\subsection{The pervasiveness of chemical protection}

There are calls for sustainable agriculture, whether at a global level or in circular circuits (Byerlee et al. 2009; LaCanne and Lundgren 2018); in these contexts, there is a legitimate place for crop protection strategies that respect the environment and that take into account the ecological functioning of agroecosystems. Yet, we are still facing increasing levels of pesticide use (Guichard et al. 2017). It should be stressed that there are even negative impacts on farm-level economicse.g., farmer revenue and profitability (Lechenet et al. 2017a, b; Mourtzinis et al. 2019). Pesticide use not only remains a dominant practice, but it has steadily increased over the past 60 years and overall toxicity has also increased (Bernhardt et al. 2017; DiBartolomeis et al. 2019; Enserink et al. 2013). Hedlund et al. (2020) speak of "ever-increasing" use, and even in highly developed countries there is no sign of reduction, especially in large-scale field crops (Piwowar 2021). This is exactly what has been observed in most agricultural production systems, with an ongoing proliferation of chemical control at best complemented with some other measures (Coll and Wajnberg 2017a; Lucas et al. 2017; Peshin and Zhang 2014).

Farmers are often reluctant to give up agropharmaceuticals because of their ease of use, their proven short-term effectiveness, their cost-effectiveness in most of the production situations, and because they are seen to guarantee fewer production losses. There have been cases where a well-established IPM was abandoned in favor of uncontrolled pesticide use. Toleubayev et al. (2011) give the example of Kazakhstan after the fall of the Soviet Union in 1991. The systematic reappearance of pesticides is linked to brutal changes in organizational and institutional frameworks which disrupted research, training and collaborative work. However, the phytosanitary training and monitoring of farmers is often undertaken by representatives of the agrochemical industry (Ohmart 2009). This explains why farmers remain dependent on pesticides (Epstein and Zhang 2014; Matyjaszczyk 2019) and why pesticide use has not declined is even increasing in some countries. This is true for Europe (Buckwell et al. 2020), under the directive on the sustainable use of pesticides (2009/128/EC), despite national plans to reduce the use of pesticides; in France, there was a $25 \%$ increase in the use of agricultural pesticides between 2011 and 2018 (Guichard et al. 2017). This is also the case in the US (Meehan and Gratton 2016), China (Zhang et al. 2011), India (Peshin and Zhang 2014) and in most developing countries. For Ehler (2005), IPM can be considered as Integrated "Pesticide" Management (Peshin and Zhang 2014) and it remains the dominant practice in California, the birthplace of IPM (Rosenheim et al. 2020). In this American state, Epstein and Bassein (2003) do not record any decrease in pesticide use. Despite some successful experiences [e.g., IPM on Bemisia tabaci on cotton in Arizona (Naranjo and Ellsworth 2009)], there an increase in insecticide use in the United States between 1997 and 2012 (Meehan and Gratton 2016).

The example of the development of IPM in the European Union deserves to be described. IPM is now the cornerstone of crop protection, since European Directive 2009/128/EC made 
the application of IPM principles mandatory in 2014 (Barzman et al. 2014). This directive raises questions of substance. Firstly, the IPM principles it promotes did not correspond to an explicit and orderly description of practices, which were only presented later (Barzman et al. 2015). Second, there is no explicit document on the operational of an ordered phytosanitary strategy in the field describing the content of practices. This makes it difficult, if not impossible, to monitor the application of IPM in the field (Matyjaszczyk 2019; Thiel et al. 2021). Thirdly, the application of this directive, which took effect on 1 January 2014, "transformed" all areas that were not considered to be in IPM on 31 December 2013 (e.g., that were cultivated with a conventional chemical protection program) into areas cultivated in IPM the following morning. Should not this be an eye-opener? Fourthly, apart from principles 1 (prevention), 2 (monitoring), and 3 (preference to non-chemical methods, which is not applied in the field) proposed by Barzman et al. (2015), the other principles concern agrochemical protection, with priority given to the search for efficiency in the use of agrochemicals. Moreover, it is to be feared that the efforts made to improve the efficiency and good conditions of pesticide use, in the drafting of most of the IPM principles of the European directive, paradoxically contribute to legitimizing and facilitating their use in the field even more. Since the IPM was made mandatory by directive 2009/128/EC (i.e., "compulsory IPM"), Matyjaszczyk (2019) highlights the difficulties encountered in the field: no available alternatives to pesticide treatments; lack of available intervention thresholds for triggering these treatments; lack of effective biopesticides; lack of farmers' knowledge on preventive measures; low economic profitability. Buckwell et al. (2020) point out that the strategy to reduce farmers' dependence on pesticides is not working well in practice. Lefebvre et al. (2015) consider that it is necessary to implement public incentive policies so that farmers are truly motivated to adopt IPM, without favoring agrochemical practices.

However, relevant ways of looking at IPM and experiences that have worked well in the real world should be mentioned. Thus, in order to control pest populations within a delimited area, a variant of IPM, the "area-wide IPM" (AW-PM) has been proposed (Vreysen et al. 2007), and has been widely developed as a complement to the more frequent "field-byfield IPM" approach mentioned by Spurgeon (2007). The AW-PM delimited area can be large (landscape, region, country, several countries), but it can also be, in principle, a closed environment such as a greenhouse. AW-PM has existed for a long time and has shown undeniable success on a large scale (Vreysen et al. 2007). This is the case of suppression or eradication of fruit flies, where a first phase of reducing pest populations using different techniques, sometimes chemical, is then followed by a second phase of eradication using other techniques, sometimes biological, such as the Sterile Insect Techniques. The suppression of different species of fruit flies in Hawaii (Vargas et al. 2008) and the eradication of the Mediterranean fruit fly (Ceratitis capitata Wiedemann) in Mexico (Enkerlin et al. 2015) are perfect illustrations of such a technical, economic and social success. This is also the case of the transgenic cultivation of cotton plants in China (plants integrating up to 3 genes coding for Bt toxins), which were given free of charge to smallholder farmers for the management of Helicoverpa armigera $\mathrm{Hb}$. which had become resistant to insecticides (Tabashnik et al. 2010). Even if there have been outbreaks of non-target mirid bugs ( $\mathrm{Lu}$ et al. 2010; Li et al. 2020), this strategy allowed a large-scale return of beneficial arthropods to horticultural crops adjacent to cotton crops, allowing the reduction of pesticide use ( $\mathrm{Lu}$ et al. 2012) and promoting arthropod pest suppression ( $\mathrm{Li}$ et al. 2020). These AW-PM successes have been made possible by the involvement of governments or governing bodies in decisions taken on a large scale in the regions under consideration, but also sometimes collectively by several countries, while involving various actors, particularly citizens, who have a role to play. In these movements, smallholder farmers have been encouraged to participate in the cooperative management of pest populations. While IPM is often considered in the field as a toolbox (often chemical) in a curative approach on a local scale, AW-IPM, a combination of large-scale top-down preventive approach and bottom-up field by field curative approach, has proved to be particularly suitable for insects that are highly mobile on large scales, whether they are crop pests or vectors of animal or human diseases (Wyss 2006). It is a promising way to maintain populations within their functional area (Birch et al. 2011), but it also requires detailed knowledge of the biology and ecology of the pests concerned (Brévault and Bouyer 2014). In such an approach, the different techniques can show a real synergy if they are cleverly integrated in a well delimited spatial context (Tabashnik et al. 2010). Even if it plays a significant role, the field-by-field scale is inadequate on its own.

\subsection{The IPM nebula}

For over 50 years, the numerous definitions of IPM have given rise to different interpretations, confusion and even abuse. Many appellations have tried to embody the systems observed in the field, depending on the level of chemical pressure or the importance of techniques alternative to chemicals: conventional IPM, bio-intensive IPM, preventive IPM, community IPM, zero IPM, low IPM, high IPM, ultimate IPM, etc. Figure 7 presents, in the form of a word cloud, the thirty most frequently encountered IPM wordings in the literature. This confirms that IPM can be adapted to all contexts and that a qualifier is often required to identify the system being referred to. By way of illustration, IPM is considered compatible both with conventional farming (Dufour 2001), which is the case in most countries, but also with organic farming (Baker 
Fig. 7 Word cloud representing the diversity of Integrated Pest Management (IPM) expressions found in the literature

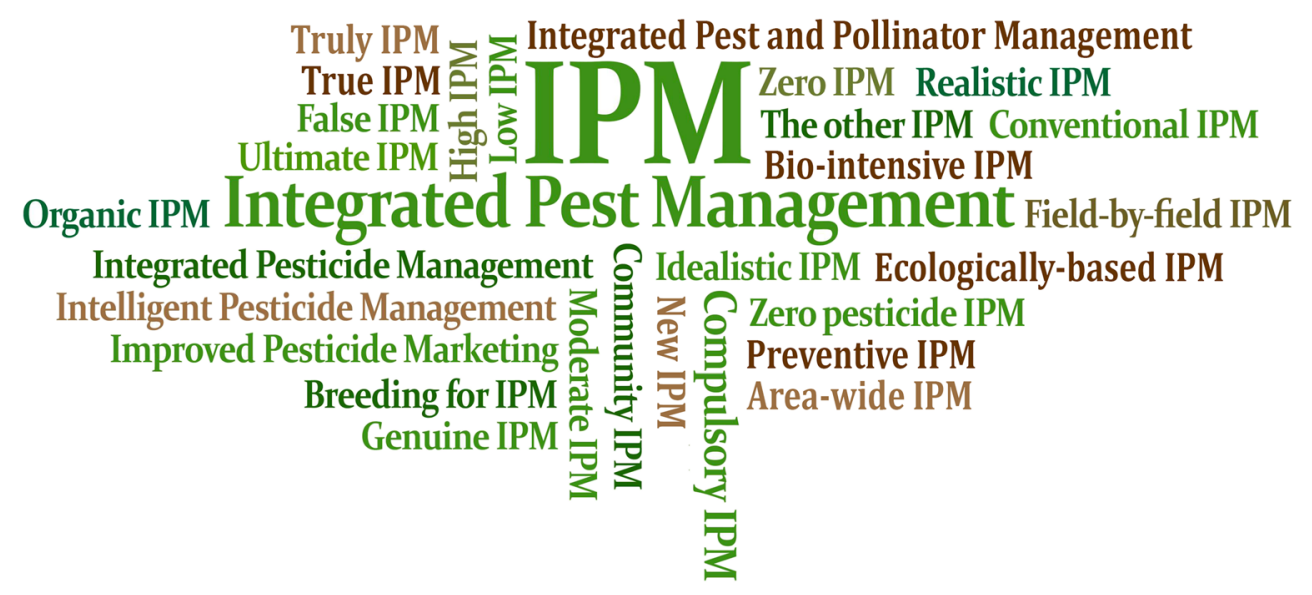

et al. 2020; Haldhar et al. 2014). Perrin (1997) speaks of "zero pesticide IPM" compatible with principles of crop protection in organic farming (Boisclair and Estevez 2006; Muneret et al. 2018; Zehnder et al. 2007).

Alongside the success story of AW-IPM in the examples above, Ehler and Bottrell (2000) question if the philosophy of IPM is actually applied in the field, speaking of "the illusion of IPM"; Coll and Wajnberg (2017b) discuss "disillusionment with IPM." Spurgeon (2007) discusses the nebulous terms of IPM.

Ehler (2006) distinguishes "True IPM," which uses chemical control only as a very last resort, from "False IPM," which is largely based on chemical control, and is much more widespread (Foucart 2019; Lucas et al. 2017), both in countries with intensive agriculture and in developing countries (especially on rice and cotton). The acronym "IPM" has sometimes been parodied to reflect agrochemical reality in the field, where it is simply a euphemism for pesticide management: "Integrated Pesticide Management" (Peshin and Zhang 2014), "Intelligent Pesticide Management" (Nicholls and Altieri 2004), or "Improved Pesticide Marketing" (Dufour 2001).

In the ESR (Efficiency-Substitution-Redesign) approach to move from conventional to sustainable agricultural systems (Hill and MacRae 1995), most IPM definitions correspond to stage $\mathrm{E}$ (improving the Efficiency of chemical protection) or S (essentially the Substitution of chemical pesticides by other means). The "true IPM" of Ehler (2006) and the "truly IPM" of Thomas (1999), with its ecological bias, correspond to the stage R (Redesign) because they imply a complete redesign of the production system, as highlighted by Lechenet et al. (2017a, b).

The fact that IPM is pest-centred inevitably requires additional details in its design when dealing with other trophic groups. For example, in an attempt to optimize simultaneous management of pests and beneficial pollinators, Flöhr et al. (2018) introduced the concept of IPPM (Integrated Pest and Pollinator Management). To help farmers in decision making, they propose the concept of joint economic impact level (jEIL), which takes into account the economic injury level of pests, as well as the economic benefits of pollinators. This direction is supported by Egan et al. (2020), who proposed a systematic framework to integrate pollinator services into IPM. They justify the existence of IPPM by the fact that IPM does not explicitly favor pollinators. In this logic of including more trophic groups in IPM, some authors have proposed IPPPM (with predators as an additional element) (Dangles 2020, personal communication). We could suggest IPPPPM (including parasitoids) and could go even further (e.g., IP ${ }^{6} \mathrm{M}$ including pathogens and parasitic plants). This highlights the limitations of pest-centric IPM definitions.

Benbrook (1996), Hollingsworth and Coli (2001), and Ohmart (2009) consider IPM to be a "continuum" of practices arising from the confusion created by its many definitions. We begin with "low IPM," equivalent to sustainable chemical control, and "False IPM" (Ehler (2006), moving to "moderate IPM" and "high IPM," similar to "Genuine IPM" (Hill and al. 1999), and finally "ultimate IPM" and "true IPM" (Ehler 2006). Every crop protection practice on the planet fits into the innumerable systems along this IPM continuum. This notion of continuum has its limits, for example when IPM itself becomes Integrated Pesticide Management_-and becomes intertwined with Integrated Resistance Management, as a strategy to rotate synthesized active ingredients, i.e., an efficiency-based approach heavily endorsed by the agrochemical industry.

The acronym IPM is indeed so anchored in the minds of scientists, farmers, decision makers, industry workers, trainers, and teachers, that Zalucki et al. (2009) suspect that whatever approach is used in future to protect crops, it will be called IPM. In certain research institutes, it is not uncommon to call "IPMists" all scientists working in the crop protection domain.

Differences in perception have generated bottlenecks, which have long been highlighted by Jeger (2000), meeting 
the challenges of sustainable development. Like him, other authors (Barzman et al. 2014; Dara 2019; Ehler 2005; Hokkanen 2015; Stenberg 2017) consider that IPM has a political and commercial, as well as scientific and technical component. Lucas et al. (2017) highlight the lack of coherence between science, practices, and policies in IPM. Hokkanen (2015) questions the rationale behind IPM: "IPM at the crossroads: Science, politics or business (as usual)?" Based on this observation, IPM is not consistent and not compatible with objectives of sustainability, particularly ecological, expressed above.

\section{Inadequate research on IPM}

\subsection{Gaps in research programs}

The lack of integration in the field is also noted in scientific research (Birch et al. 2011; Ehler 2006; Lucas et al. 2017; Stenberg 2017). This disparity is primarily observed in the field of academia, which is often engaged segmentally and suffers from disconnected cognitive research: the acquisition of biological knowledge, the study of control techniques, etc. On the other hand, integrative, interdisciplinary research, for example on aerial and soil biodiversity and its interactions with agroecosystem components, landscape ecology and its renewed scales (Begg et al. 2017; Brewer and Goodell 2012; Redlich et al. 2018), socio-economic research bringing the market closer to the field, social ecology, even psychosociology (Hill 2014) or studies in farm support, are still very rare (Deguine et al. 2017).

This lack of scientific integration has existed for decades and continues today. Most of the recent works on IPM still tend to list and describe tactical solutions separately, in specific contexts (Abrol 2014) rather than scientifically understand the advantage of using them together to harness their synergy (Capinera 2014; Stenberg 2017; Struelens and Silvie 2020). The same is true if we examine the experiences of the past decade in which IPM has been a driving force for innovation in crop protection. Most often, studies deal separately with protection techniques and the results give rise to solutions which can be juxtaposed but not integrated. In addition, in the majority of situations, studies are based on a single pest, a single crop, a specific context, without a broader approach taking into account all pests, or even all management constraints faced by farmers, in a socio-technical non-generic whole (Lamichhane et al. 2015; Lucas et al. 2017; Ricci et al. 2011). There are, however, some notable exceptions, such as the European "Pure" project on field crops, a multisite project with comprehensive IPM solutions with diversified crop sequences as an important tool (Vasileiadis et al. 2017). Finally, in the aforementioned research, use of chemicals is often widespread. Pesticide reduction policies favor, for example, studies on those that are the least dangerous for human health and the environment (Eddleston et al. 2002; Farrar et al. 2018; Jepson et al. 2020; Robinson et al. 2020; Whiteker 2019). This general trend, boosted by the plant protection industry, endorses and helps to legitimize the use of synthetic pesticides in crop protection and in IPM schemes. However, this is not necessarily the case: for example, Jepson et al. (2020) list a fair number of new, highly hazardous products (e.g., neonicotinoids) that were initially developed for their user-friendly application methods as coatings or prophylactics. The industry is less committed to developing environmentally friendly products than is commonly believed. Unless it is pushed by restrictive policies, there will be no easy shifts. Pesticide research is also accompanied by studies reforms the eco-efficiency of IPM and developing biopesticides to better account for agroecosystem sustainability (Magarey et al. 2019; Struelens and Silvie 2020). However, expanding research into cropping system management with integrated crop protection is needed in certain continental or national plans to reduce pesticide use (Lamichhane et al. 2016; Lamichhane et al. 2019). This need for integration also applies to IPM components such as genetic leverage. It needs to be emphasized how host plant resistance is a part of the IPM pyramid and it is a central preventative measure. A European initiative is trying to launch a new area of research, "breeding for IPM," by integrating varietal creation programs into the design of cropping systems (Lamichhane et al. 2018).

Stenberg (2017) describes the needs of modern IPM, with more studies on the different techniques, especially the compatibility and optimization of techniques - integration-oriented research that has seen less than satisfactory results in spite of a few exceptions (Lescourret 2017). It is recognized that control practices interact with each other and that they can have synergistic or antagonistic effects when used together. Numerous publications advocate such an approach, including, to cite but one very striking example, that of Lewis et al. (1997). Promoting these synergies is the challenge faced by IPM research according to Birch et al. (2011). These authors add that we can only speak of "truly integrative pest management" when research focuses on a complete redesign of cropping systems and promoting biodiversity at every scale. In the same vein, other researchers suggest promoting cultivated or wild plant biodiversity in agroecosystems, in order to strengthen not just pest regulation but also other ecosystem services and agroecosystem stability (Altieri and Nicholls 2004; Bianchi et al. 2006; Duru et al. 2015; Ferron and Deguine 2005; Gaba et al. 2015; Hoy 2020; Hufnagel et al. 2020; Isbell et al. 2017; Kiritani 2000, 2020; Landis 2017; Lescourret et al. 2015a; Lundgren and Fausti 2015; Malézieux et al. 2009; Ratnadass et al. 2012; Tilman et al. 2006).

Frisbie and Smith Jr 1991 and Rutherford and Conlong (2010) speak respectively of 'biologically intensive IPM' and "bio-intensive IPM," which consider the interactions 
between the different elements of an agroecosystem and tritrophic interactions (pests - natural enemies - plants) on an enlarged spatial scale. This is advocated by Ratnadass et al. (2012) for crop pest control, as well as by Ahmed et al. (2016) for the protection of beneficial insects.

\subsection{Gaps in scientific approaches}

The lack of research into IPM can also be seen in the approaches used. In addition to the interdisciplinarity shortcomings mentioned above, it is often reported that IPM research does not often use systemic and participatory approaches (Barrera et al. 2020a and 2020b; Birch et al. 2011; Dara 2019; Deguine et al. 2017; Lucas et al. 2017; Stenberg 2017). In their study on biological control, Wyckhuys et al. (2018) provide an effective and generic conceptual framework to understand IPM diffusion/adoption; in particular, these authors highlight how only scant attention is paid to social sciences.

Flaws in the systemic approach to IPM have long been noted (Stenberg 2017). In an analysis of 107 publications published between 1991 and 2012, Schut et al. (2014) show that only a small number has systemic approach, the majority being technical or technological. Only a quarter of the IPM definitions identified by Bajwa and Kogan (2002) refer to the word "system." In IPM, there is a predominance of a "pestcentric" perspective rather than an interdisciplinary systems/ holistic perspective (Chaplin-Kramer et al. 2019; Coll and Wajnberg 2017b; Lewis et al. 1997; Rosenheim and Coll 2008; Teng and Savary 1992). In France, Ricci et al. (2011) suggested "rethinking crop protection," while retaining integrated crop protection, the French equivalent of IPM. Ricci and Messean (2015) argue for a systemic approach that "goes beyond the framework" of a simple substitution for pesticides. In their "holistic pest management" approach, Barrera (2020a) consider that IPM is essentially pest-oriented, not especially crop-oriented and even less farmer-oriented. Hoy (2020) recalls that a recent query on the Web of Science for papers with keywords "agroecosystem management" (or "agroecosystems management") and "Integrated Pest Management" (or "IPM") resulted in a single reference (a presentation on horticultural pests from an ecological control conference). This lack of a systemic and holistic approach is reflected in the narrowness of the disciplinary spectrum of IPM, which has long lacked significant investment in the humanities and social sciences (Goodell 1989; Hill 2004 and 2014; Ruesink 1980). This is really critical: IPM continues to be largely taken forward by mono-disciplinarians. Maybe this also shows our inability to effectively break "lock-ins" of farmers... Crop protection scientists alone will never be able to "unlock" this, nor will social scientists if they act alone. This lack also reflects the need to fill the gap between researchers and farmers (Sherman and Gent 2014; Zalom 1993). Dara (2019) goes even further and points out that no IPM model takes all factors into account, such as farmers' education level, socio-economic conditions, environmental concerns, ethical values, regulatory frameworks, public policies, availability of control techniques, extension and training, consumer preferences or market characteristics. This author insists on the importance of research and a move towards "New IPM," which includes sustainability, management and business.

IPM has also suffered from a lack of farmer involvement during research (Ohmart 2008) both in the Southern hemisphere (Litsinger et al. 2009; Parsa et al. 2014; Waage 1998) and in the Northern hemisphere (Penvern et al. 2019; Vreysen et al. 2007). With more involvement, farmers could contribute to research with their wide and empirical knowledge on beneficial insects, animal pests or other living organisms, and on traditional protection methods (Altieri and Nicholls 2017; Wyckhuys et al. 2019a). The latter authors believe that properly training farmers on natural enemies of pests and the importance of ecosystem services would reduce their dependence on pesticides. Furthermore, by bringing together the issues faced by both researchers and farmers, they could be trained on the different practices at their disposal and, above all, on the importance of making them compatible and orderly.

\section{Inadequate consideration of ecology in IPM}

\subsection{A move away from the roots of ecology towards chemicals}

Research on IPM does not sufficiently take ecological processes in agroecosystems into account and therefore, their resilience to pests (Lucas et al. 2017; Walter 2005). "Whatever happened to IPM?" ask Peterson et al. (2018), faced with the progressive disappearance of the primary aims of IPM, regretting in particular, like Dufour (2001), the decline in status of ecology since the "supervised control" of Smith and Smith (1949). It may be added that there is also no emphasis on agronomic considerations or non-chemical prevention.

We note that there has been a focus on control methods in IPM rather than on the agroecosystem as the object of IPM (Lescourret et al. 2016); this has resulted in the aforementioned lack of research integration, and pesticide use, driven by the agropharmaceutical industry, is seen by farmers as simple and easy to apply in the field.

Coll and Wajnberg (2017b) note the lack of ecology in the various definitions of IPM identified by Bajwa and Kogan (2002). In comparison, economic profitability is universal (Onstad and Crain 2019). As a result, over the 60 years of IPM's existence, ecology, which is largely incompatible with the use of chemicals, has been neglected. Moreover, in cases where the concept of ecology is used in IPM, 
environmentalism is referenced more often than ecology, i.e., the aim to reduce negative environmental impacts (Lucas et al. 2017), rather than using ecological processes to replace chemical pesticides (Geiger et al. 2010; Lescourret et al. 2015b; Ratnadass and Barzman 2014). At most, pest population dynamics (which indeed pertains to the scientific field of population ecology) are studied in order to set economic thresholds.

Over several decades, Stuart Hill has highlighted a lack of ecology in the humanities and social sciences: he has always campaigned to promote social ecology and psycho-economics in IPM (Hill 2004 and 2014; Hill et al. 1999) in order to change food systems.

\subsection{Calls for more ecology in crop protection}

Since the start of the millennium, the harmful effects of pesticides on human health have been assessed and have become major concerns (Bourguet and Guillemaud 2016; Eddleston et al. 2002; Hoppin and LePrevost 2017; UN 2017; Schäffer et al. 2018). Thus, today, the issues of ecological sustainability of agroecosystems and respect for health are as important as the "classic" issues of sustainable development (social, economic, environmental) (Barbier 1987; Dasgupta 2007; Schäffer et al. 2018; Purvis et al. 2019) and a new paradigm of agriculture is needed which recognizes agriculture's multiple roles in the development of these fields (Byerlee et al. 2009).

For several decades, authors have called for greater focus on ecology in IPM. Some have proposed an "ecologicallybased IPM" (Kennedy and Sutton 2000; Koul and Cuperus 2007), others a "truly IPM" (Thomas 1999). Other authors suggest developing the relationship with Pest Management, therefore a more pest-centred IPM: ecologically based pest management (Altieri and Nicholls 2003; Brévault et al. 2014; Zhao et al. 2016). Finally, other authors propose similar "Pest Management" approaches: a more environmentally friendly approach [e.g., Environmental Pest Management (Coll and Wajnberg 2017a)], a more agroecological approach [e.g., ecological pest management; ecological pest control; agroecological approaches for pest management (Altieri 1980; Altieri and Nicholls 2017; Brzozowski and Mazourek 2018; Hill 2004; Kogan and Jepson 2007; Lemos et al. 2011; Reddy 2017; Zhao et al. 2016; Wyckhuys et al. 2020b)] or even a more systemic and holistic approach such as holistic pest management (Barrera 2020a, b; Malézieux 2017).

Deguine et al. (2009) endorse a "crop-centred" rather than "pest-centred" approach and call for a major change of course, transitioning from agrochemical crop protection to Agroecological Crop Protection (ACP). This represents the application of agroecology to crop protection, both scientifically and practically and is described in detail (Deguine et al. 2017).

\section{Agroecological Crop Protection (ACP): towards a paradigm shift}

\subsection{Origins and definition of ACP}

The basic principles of ACP have different sources, but have ecology as their foundation, as many authors have suggested (see above). The biological and agronomic components of ecology (Hénin 1966, cited by Sébillotte 2006) are also superimposed on social and organizational ecology, which can be described as social ecology (Hill 2004; Huxley 1964). In addition, the principles of ACP are identical to the principles of agroecology from which they originate and they are also inspired by certain principles of crop protection used in organic agriculture or in permaculture. Finally, ACP takes into account the lessons of half a century of crop protection under the aegis of IPM.

ACP is a simple concept to define and to understand: it is the application of agroecology to crop protection. Like agroecology (Wezel et al. 2009), ACP has 3 dimensions. It is a scientific discipline, an ordered strategy of cropping practices, and a sociological movement within a socio-ecological framework of food systems.

Scientifically, ACP is a concept of crop protection based on cropping systems whose aim is to improve the sustainability of agroecosystems by taking into account their ecological functioning. ACP aims to promote the ecological health of agroecosystems by directly or indirectly optimizing interactions between living (plant, animal, microbial) communities both below and above the ground. ACP is built on two pillars, biodiversity (both aerial and edaphic) and soil health, in order to make agroecosystem less susceptible to biotic stresses. ACP aims to improve the health of agroecosystems by encouraging practices which enhance ecosystem services (Power 2010), such as pest regulation (Hoy 2020). Researchers have known of these principles for a very long time, but have rarely taken them into account.

The agronomic dimension of ACP is a strategy which is applied in an explicit and orderly way on the ground (Deguine and Ratnadass 2017). Here, absolute priority is given to preventive measures, both space- and time-wise, within a redesigned agroecosystem framework (Ratnadass 2020) including prophylaxis, varietal resistance or tolerance (Begg et al. 2017; Simon et al. 2014), the improvement of soil quality and health and, of course, biodiversity via habitat management or diversified farming systems (Gurr et al. 2017; Landis et al. 2000; Lichtenberg et al. 2017; Tilman et al. 2012); phytosanitary and cropping techniques such as preventive physical control or direct seeding complementing a phytosanitary and agroecosystem health assessment based on field observations. If curative measures are to be used, chemical pesticides should be mandatory should be governed by regulations, and used within very strict criteria [(notably 
using active ingredients which are less harmful to the environment (Guedes et al. 2016)]; local applications to small areas only). In addition, the broad and integrative approach of ACP makes it possible to consider the use of, alongside agroecological practices, traditional physical, biological, and genetic techniques as well as more recent technological innovations in crop protection such as biocontrol products, decision support tools, and robotics.

The third dimension of ACP is its role in agroecological transition towards more robust food systems (Hamm 2009). $\mathrm{ACP}$ is a set of interactions, in a social, institutional and ecological context, by different stakeholders involved in crop protection: farmers, researchers, decision-makers, policymakers, advisors, buyers, consumers, processors, agrosuppliers, trainers, and teachers. These interactions are a generic character of agroecology's sociological effects. Some of the components, however, are specific to crop protection because pesticides, biological control, genetically modified plants or biodiversity have both professional and personal resonance among stakeholders. This social dimension is based on the ecological and socio-economic bases of cropping systems, socio-technical systems and food systems proposed by Hamm (2009), Hill (2004), Hoy (2015), Hoy et al. (2016), Prokopy (1994) and Vialatte et al. (2019). Actors act in different spheres of influence, but they are also influenced by them. These spheres may include personal values, markets, regulations, the landscape, farm, field and knowledge.

There is a large continuum between IPM and ACP. Figures 8 and 9 show via spider graphs differences between the two paradigms, according respectively to the ESR framework (Hill and MacRae 1995; Dupré et al. (2017) and to six ecosystem services (Ratnadass 2020). In particular, Fig. 9 illustrates the ability of ACP to address overall agroecosystem performance beyond simple pest regulation, by enhancing multiple ecosystem services through the mobilisation of biodiversity in ecosystem functions.

\subsection{Case studies}

Pioneering experiments took place in cotton cultivation at the small farm level in Africa between 1990 and 2000, when it became impossible to control populations of phloem-feeding insects (in particular the aphid Aphis gossypii and the whitefly Bemisia tabaci), even after heavy insecticide applications. The agroecological approach made it possible to manage aphid populations and eliminated foliar applications of insecticides (Deguine et al. 1994, 2000, 2008). The approach was extended to all phloem-feeding insects of cotton (Deguine et al. 2008).

The first ACP experiences in intensive farming took place between 2000 and 2010 in Reunion on mango, courgette and chayote crops (Deguine et al. 2015 and 2018). These experiences brought together members of the agricultural profession and placed producers at the center of the system. It enabled comparisons of the performance of conventional horticultural cropping systems (i.e., using agrochemicals), with agroecological cropping systems. The results of these experiments were significant and encouraging, and provided valuable lessons for the agroecological transition which is taking place now (Deguine et al. 2019). Insecticide and herbicide treatments have been greatly reduced or even eliminated. On 13 mango plantations observed during 3 campaigns (from 2012 to 2014), TFI (treatment frequency index, standardized number of pesticide treatments for a given production) decreased from 22.4 to 0.3 . On courgette (Cucurbita pepo, also called zucchini or baby marrow), the pyrethroid-organophosphorus

Fig. 8 Spider graph showing the positioning (on $0-75 \%$ scale axes) of Integrated Pest Management (IPM) and Synthetic inputs ( $E$ )

Agroecological Crop Protection (ACP) according to their respective share between the components of the E-S-R framework (Hill and MacRae 1995). «E» stands for increased « Efficiency » (of synthetic inputs); « $\mathrm{S}$ » for « Substitution » (of synthetic inputs by alternative inputs split into off-farm and onfarm: cf. Dupré et al. 2017), « R» for « re-design »

Alternative on-farm inputs (S)
Alternative off-farm inputs ( $S$ )

$$
\square \text { IPM } \square \mathrm{ACP}
$$


Plant biomass production

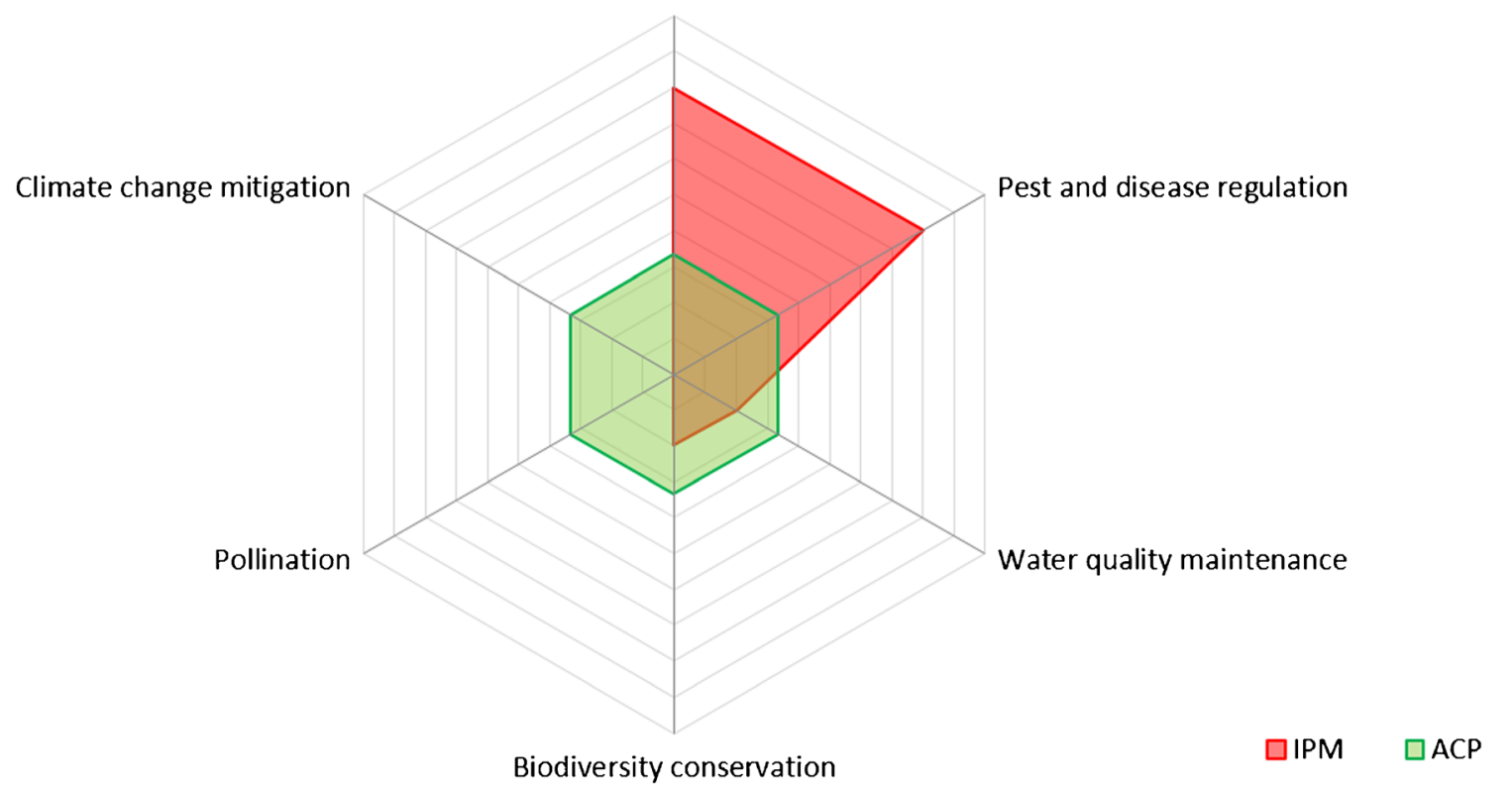

Fig. 9 Spider graph showing the positioning (on 0-40\% scale axes) of Integrated Pest Management (IPM) and Agroecological Crop Protection (ACP) according to their respective contributions to six types of ecosystem services (ES), reflecting the contribution of ACP to a range

combination applied weekly to the crop at a dose of $495 \mathrm{~g} \mathrm{ha}^{-1}$ has been replaced by spot spraying of a biological insecticide (spinosad) on trap plants at less than one gram per dose. On chayote (Sechium edule, also called cho-cho) insecticide and herbicide applications have been completely eliminated. Savings on labor are also significant: a $9 \%$ reduction on courgette and chayote, $28 \%$ on mango. Protection costs were reduced by $72 \%$ for courgette, $100 \%$ for chayote and by $66 \%$ for mango. Yield increased by over $45 \%$ for courgette and chayote and did not change for mango (Deguine et al. 2015 and 2018). In addition, in-depth ecological studies conducted on functional biodiversity in mango orchards over three years have shown that instead of a few pests and weed species seen in agrochemical orchards, nearly 800 morpho-species of arthropods and more than a hundred spontaneous herbaceous plants were observed in agroecological orchards (Deguine et al. 2018). In Reunion, public policies have taken up the torch from technical measures in the field and now offer incentives, with good results.

Other agroecological pest management experiences have taken place on different crops in mainland or overseas France and in several tropical countries during the last decade (Deguine et al. 2017). Six of these experiences are shown in Fig. 10, arranged by life history traits of the pests being studied (specificity and dispersal capacity), implementation scales of regulatory processes: from soil to field (and its close vicinity), then up to the landscape scale as well as their contribution to the 4 stages of agroecological transition described by Ratnadass (2017). of ES, not only the virtually only plant biomass (namely 4F: Food, Feed, Fiber \& Fuel) and pest and disease regulation ES (adapted from Ratnadass 2020). One should note that in absolute value, this is not at the expense of these two ES

\subsection{Moving from IPM to ACP}

During the transition to ACP, each professional will face difficulties and advantages compared to IPM. For researchers, the first hurdle is to convince stakeholders and partners that ACP is not just another concept with little improvement over IPM (in terms of break with pesticides, for example), nor simply wishful thinking coming to nought in practice because it is based on principles (in particular the substitution of nonrenewable inputs with ecological processes) which have not been proven for all production situations. A second difficulty is predicting the success rate and economic benefits of ACP: it is far more complex than predicting the effectiveness and economic return of pesticides in conventional agriculture. The cost of ACP practices and the economic benefits of the regulating services they provide need to be assessed, and this remains a challenge (Bommarco et al. 2013). Yet another difficulty for researchers is getting the ACP message across in the Global south hemisphere countries (ACP originates from the Northern hemisphere), because some of these countries, particularly in sub-Saharan Africa, did not experience the Green Revolution, and might see it as being denied access to effective technologies. This is an already controversial issue for agroecology in general. A final, more theoretical, difficulty is that in order to develop outwardly "simple" techniques (which may be perceived as retrograde by some), researchers have to deploy extremely complex analytical tools. New skills and approaches are needed, protocols for data collection have to be renewed, new disciplines invested in such as ecology 


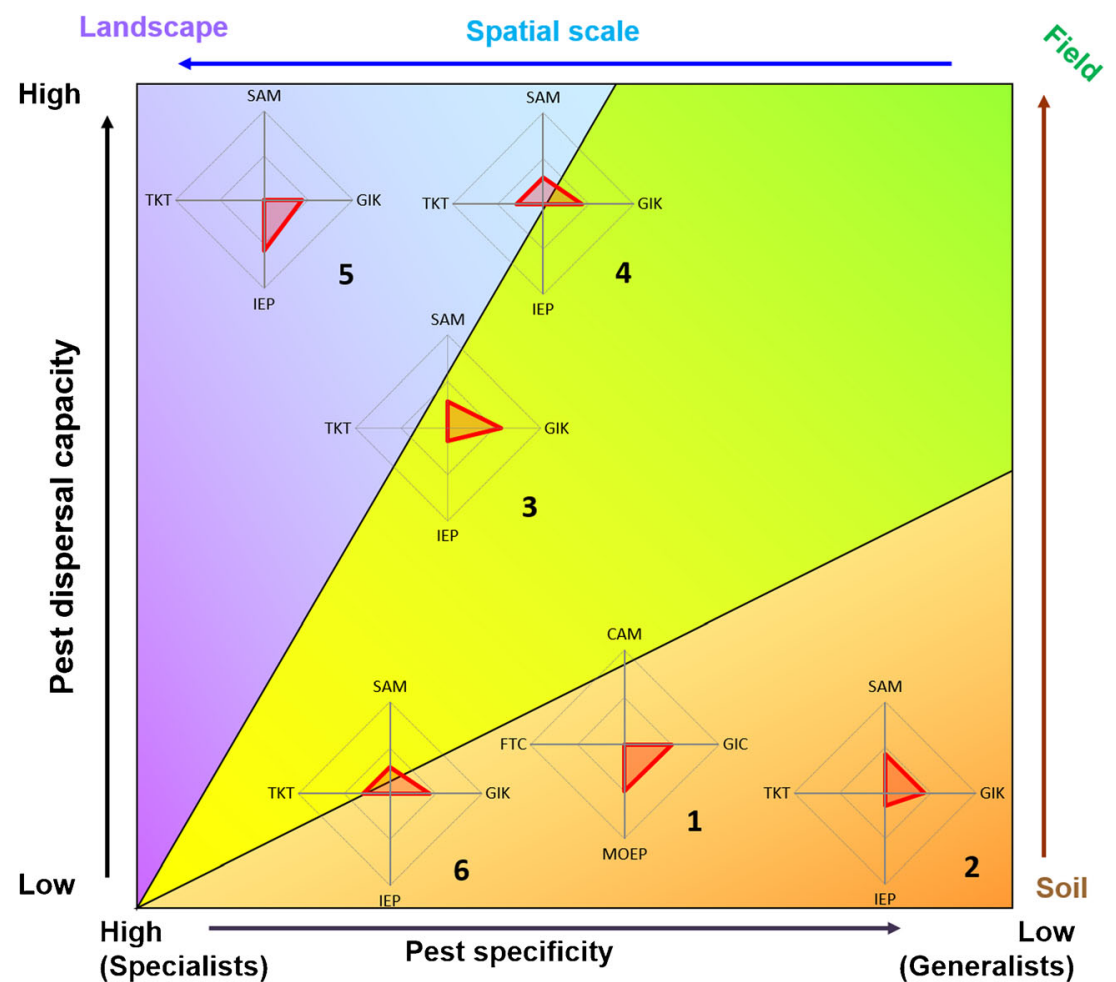

Fig. 10 Positioning of 6 Agroecological Crop Protection (ACP) case studies according to : i) the 4 agroecological transition keys (on 0 $100 \%$ scales); ii) pest life history traits (specificity and dispersal capacity) and implementation scales of regulation processes (soilfield - landscape). Agroecological transition keys: SAM = selection and adaptation of methods; GIK = generation and integration of knowledge; IEP $=$ implementation and evaluation of practices; TKT $=$ training and knowledge transfer. Case studies: 1. Agroecological management of soilborne pathogens on greenhouse vegetable crops in France (Faloya and

(e.g., chemical, community, functional, and landscape ecology), but also modeling, biomathematics or participatory research. In IPM, modeling efforts have greatly focused on threshold-based decision-making to help triger pesticide treatments (e.g., Zadoks 1981). In that sense, modeling contributed to the continued presence of the agrochemical industry in IPM programmes. Modeling also plays a key role in ACP, but with different purposes. The main role of models for ACP is to handle the highest biological complexity of pesticide-free agroecosystems. Such models notably take into account the impact of cropping practices on the biological component of agroecosystems (e.g., Deguine et al. 2021) and thus help design ACP-based cropping systems. Like for IPM, a secondary role of models for ACP is to help threshold-based decisionmaking for curative treatments as a last resort (but not especially for chemical use). The main differences between models used for IPM and models used for ACP are the underlying conceptual frameworks, which represent more or less explicitely the ecological functioning of the agroecosystems considered agroecosystems. Increasingly, researchers adopt new modes of thinking, for example, to take into account the option by context interactions (Sinclair and Coe 2019).
Jeannequin 2017); 2) Agroecological management of tomato bacterial wilt in Martinique (Deberdt and Fernandes 2017); 3) Resident vegetation cover management to control apple orchard pests in France (Simon et al. 2017b); 4) Agroecological management of mango fruit flies in Benin (Sinzogan et al. 2017); 5) Agroecological management of banana pests in the Dominican Republic (Gandini et al. 2017); 6) Agroecological management of soil-dwelling pests of upland rice in Madagascar (Randriamanantsoa and Ratnadass 2017)

Acquiring such tools and skills takes time and a certain capacity to adapt. Conversely, this aforementioned difficulty can be taken by researchers as a highly motivating challenge.

For producers, transition to ACP generally leads to a structured and orderly reorganization of their practices as compared to conventional solutions, which are deemed more manageable and less risky, at least in the short term. ACP is seen by many farmers as a "leap into the unknown," especially in the absence of risk insurance. There is also the psychosocial issue and perception that ACP is less "high tech" than other approaches, which can even give the impression of taking a step backwards (vis-à-vis other producers). In addition, using indigenous beneficial organisms can be perceived by the farmer as losing control of cropping system management, even worsened by the fact that the effect of these "invisible" beneficial organisms is not as immediate and observable as using pesticides, or physical measures such as anti-insect nets.

An advantage is that producers may see their profession as being upgraded by transitioning to ACP, which translates into the management of complex and diversified systems, the preservation of the environment and the safeguarding of human health, namely a very positive image of their responsibilities, 
above and beyond their mere role of food producers. Another advantage for researchers is the fact that ACP meets the expectations of society (especially consumers) and current environmental policies (decision-makers and donors). Resources and dedicated facilities are therefore allocated to research (e.g., funds from Ecophyto, the French national action plan for pesticide reduction; calls for projects from certain private foundations). In this context, ACP researchers have a vocation both to inform policy, but also to feed the message carried by extension workers and advisers.

Experiences in ACP in recent years make it possible to identify necessary generic conditions and lessons for the design and implementation of future agroecological experiments in different contexts. Deguine et al. (2019) therefore proposed a list of certain conditions which are necessary, but not sufficient, for the development of large-scale agroecological experiments: i) awareness and motivation of agricultural groups and other stakeholders, starting with producers. This important work is undertaken by technical partners, each with means and tools; ii) a unifying phytosanitary problem, with either a socio-economic or environmental deadlock, or the possibility of taking a significant step towards the adoption of greener agroecological practices with access to new markets that such a move would provide; iii) research capacity, which will improve the scope and content of research, leading to the integration of new, better scientific knowledge; iv) synergy between research and development to bring together the complementary activities of partners (research, experimentation, training, teaching, advice, transfer); v) a research and development project in partnership - the preparation and organization of which would require several conditions to be met (collective sharing of circumstances, co-design of programs to be implemented, coordination of actions by a transfer organization); vi) a systemic and participatory approach (Fig. 11), at the right spatio-temporal scales and with revised criteria which take into account the ecological sustainability of agroecosystems; vii) support from public authorities both before and during the agroecological transition period; viii) permanent interactions between the groups involved (from farmer to consumer), in dynamic, robust food systems.

In general, the transition to ACP is based on four mutually reinforcing pillars: i) choice and adaptation of practices; ii) integration of knowledge, iii) implementation and evaluation; iv) training and diffusion of knowledge (Deguine et al. 2017). In order to implement ACP on the ground, a set of basic practices can be used, primarily preventively. These techniques are not to be implemented simultaneously, but must rather be chosen, adapted and integrated in an orderly manner in reasoned cropping systems with the aim of establishing a suite of ecosystem services. Knowledge should therefore be integrated whether it comes from field or laboratory, regional agricultural diagnoses, simulations, expertise or scientific and technical articles. This can require qualitative modeling such as that based on the IPSIM platform (Aubertot and Robin 2013). This innovative approach has the advantage of democratizing modeling activities and bridges the gap between scientists and other stakeholders involved in ACP. This knowledge sharing makes it possible to better adapt cropping systems to production situations with different physical, biological, chemical, and socio-economic requirements (Aubertot and Robin 2013) and to the farmer's own objectives. Once these systems have been designed, they should be implemented either through gradual modification of existing systems, or through a brand new design (Meynard et al. 2012). Each performance measure of these systems must then be assessed using a multiple criteria method such as the one proposed by Deytieux et al. (2015).

The development of ACP requires continually advancing operational and actionable knowledge. It is therefore important that the initial basic training is continuously updated through formal training, self-training books, technical journals or online resources, and through regular exchange with other members of the profession: farmers, agricultural advisers, development engineers or researchers (Deguine et al. 2017). It is also important that knowledge is accessible to other groups: representatives of cooperatives, extension organisations,

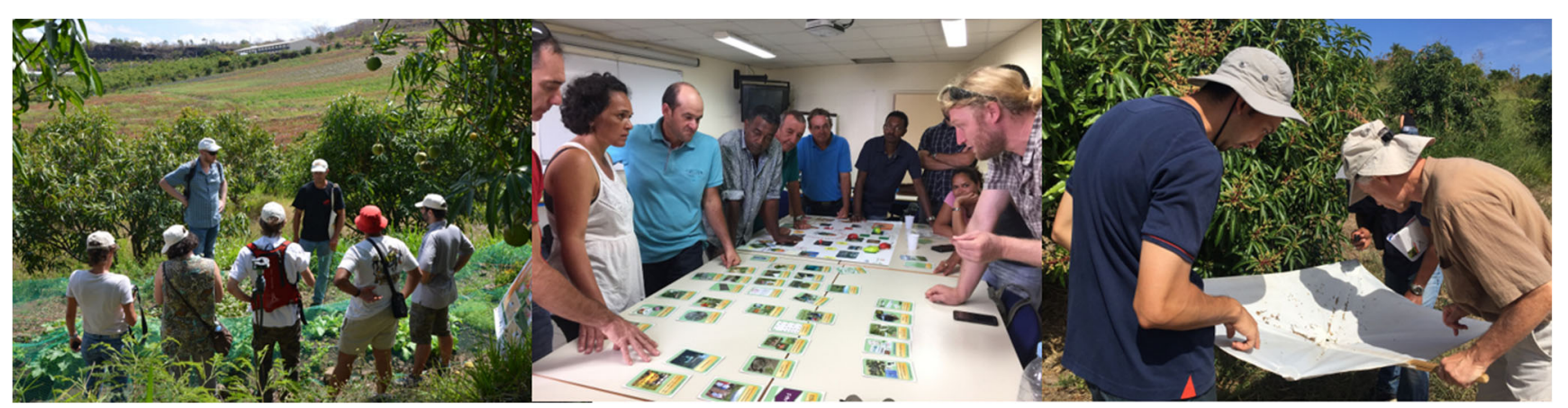

Fig. 11 Participatory research approach in the framework of the design of an Agroecological Crop Protection (ACP) experiment (mango orchards in Réunion, France). 1. Discussion in the field between researchers, farmers and advisors to compare the results obtained with the expected

results. 2. Role-playing allowing farmers to be confronted with situations to be managed. 3. Collective monitoring of pest and beneficial populations in an orchard. Photos: (C) Jean-Philippe Deguine-CIRAD 


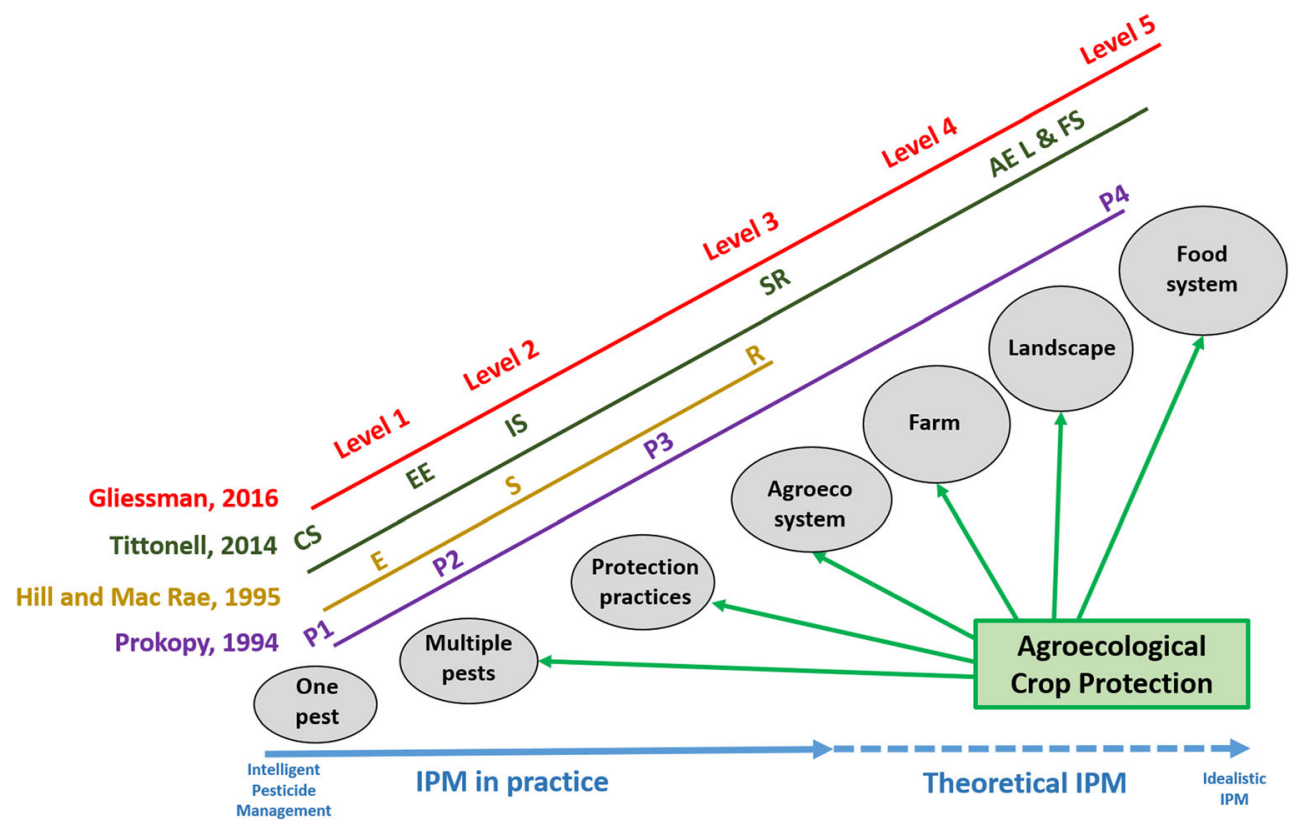

Fig. 12 From Integrated Pest Management (IPM) to Agroecological Crop Protection (ACP). Transition between agrochemical pest management and healthy agroecosystem \& food system management. This figure shows the objects of study and the concerns that are the main focus of IPM and ACP, as well as scales of reasoning and practice. The figure is based on the conceptual approaches of the following authors: Prokopy 1994 (P1 = IPM within a single class of pests; P2 = IPM across all classes of pests; P3 = IPM in concert with practices; P4 = IPM in relation to psychological, social, political and legal constraints); Hill and MacRae 1995 (E = Efficiency ; S = Substitution ;

public authorities and consumers. Tools for dissemination and extension of ACP, including training approaches such as fieldschools and other participatory schemes build on what worked for IPM. It should also benefit from the development of digital learning platforms and other novel communication tools. All these interactions should contribute to the development of social and organizational ecology and robust food systems (Hamm 2009).

\section{Conclusion}

Overall, despite 6 decades of good intentions, harsh realities need to be faced for the future: i) the numerous definitions of IPM have resulted in confusion and different interpretations by members of the profession; ii) inconsistencies between the concept of IPM and practices and public policies are widely-recognized; iii) unguided (often prophylactic) chemical control remains the cornerstone of many IPM programs; iv) the use of chemical control only as a last resort (as per IPM guidelines) is rarely adopted by farmers; v) IPM research is often inadequate, both in programs and scientific approaches; vi) ecology is not sufficiently taken into account in IPM.
$\mathrm{R}=$ Re-design); Tittonell 2014 (CS = Current systems; EE = Ecoefficiency; IS = Input substitution; SR = System re-design; AE L\&FS = agroecological landscapes and food systems); Gliessman 2016 (Level $1=$ Increase the efficiency of industrial and conventional practices; Level $2=$ Substitute alternative practices for industrial/conventional inputs and practices - levels 1 and 2 focus on the protection system only; Level 3 $=$ Redesign the agroecosystem so that it functions on the basis of a new set of ecological processes; Level $4=$ Re-establish a more direct connection between those who grow our food and those who consume it; Level $5=$ Construction of a new global food system)

Today, IPM has arguably reached its limits (as suggested in Fig. 6) and the people who have worked in IPM, including the authors of this review, have completed their mission (Barrera 2020a). Recent years have seen emerging calls for a "green revolution," biodiversity-friendly agriculture, transformative change in global food systems, or the need for sustainable food production to enable all to benefit from healthy diets (Beddington 2010; Pretty et al. 2018; Willett et al. 2019). We now believe a change of course is necessary: an intellectual revolution and a break with current practices. Generally, concepts evolve in small adjustments and turns, but sometimes a genuine revolution is necessary, i.e., when a concept no longer suits the context and challenges of a sector. This requires a paradigm shift, proposed by Kuhn (1962): a new, defined and recognized scientific concept, bringing together a large number of researchers espousing the new approach and proposing new solutions to the problems encountered by farmers in the field. Like other authors (e.g., Letourneau et al. 2017), on the ground it seems to us that radical changes in crop protection are now needed, instead of the small adjustments made to IPM, which supported various forms of agriculture, including intensive agriculture, based on monoculture and large quantities of inputs, particularly pesticides. 
Agriculture is today faced with severe ecological, sanitary, social, economic and environmental challenges. We are proposing a paradigm shift by endorsing the universal adoption of ACP - the application of agroecology to crop protection. Like agroecology, ACP has 3 aspects: it is an interdisciplinary science; an organized strategy of agronomic practices; a form of social ecology combining the stances and interactions of food system stakeholders. Drawing on the work of Prokopy (1994), Hill and MacRae (1995), Tittonell (2014) and Gliessman (2016), Fig. 12 shows the multifactorial development of the IPM continuum into ACP, highlighting trends in protection, approaches, scales, and levels of action.

Compared to pest management concepts that have crossed the last six decades, ACP is based on agroecological principles, taking ecology as its guiding principle. ACP is not pestcentred and seeks to promote agroecosystem health, which is reflected in recent guidelines (FAO 2020). ACP can benefit from relevant strategies such as AW-IPM, which allows a large-scale preventive approach to be complemented with curative tactics at plot level, while involving national or regional organizations and different actors in society (Vreysen et al. 2007). In this respect, and facing dangerous, invasive, polyphagous and highly mobile pests, e.g., the oriental fruit fly Bactrocera dorsalis (Hendel), the large-scale agroecological preventive strategy of ACP could be judiciously complemented by curative and local practices in a "multi-crop centred" approach when necessary. Finally, there are decision rules in the ACP phytosanitary strategy to be applied in the field which warn against advancing to the next stage unless the previous one has been implemented.

ACP represents a real change of course and requires the redesign of entire farming systems using a "cropping systemoriented" approach (Ratnadass 2020). One can assert that ACP has similarities with the concepts of ecological intensification (Bommarco et al. 2013; Doré et al. 2011; Ratnadass and Barzman 2014; Tittonell 2014) and Japanese IBM (Kiritani 2000). We also note the perfect coherence with the contributions from soil health and biodiversity to ecosystem services and bundles of services (Petit and Lescourret 2019).

The transition from IPM to ACP requires both words and action. The words adopted by ACP illustrate its systemic, multi-scale and participatory approach, as proposed by Meynard et al. (2012). Unlike IPM and its countless variants, which are "pest-oriented" (Pest Management), the acronym ACP is "crop-oriented" (Crop Protection) and implies a systemic approach (cropping system-oriented). ACP clearly indicates a direction of travel where ecosystem services are promoted, a holistic approach with priority given to the design of ecologically healthy agroecosystems (Deguine and Penvern 2014; Hoy 2015; Wezel et al. 2014). Crop protection is built on bioecological balances arising from multiple interactions between the plant, animal, and microbial communities present in agroecosystems (both in and above the soil). As such, crop protection takes priority in crop system management, whose aim is to produce healthy plants in robust agroecosystems.

Finally, ACP also represents a profound change in scientific approaches, crop protection and its associated measures. Redefined and sustainable research programs and approaches and a broad and systematic phytosanitary strategy in the field are vital to agroecological transition. To ensure a complete transition from IPM to ACP rather than small adjustments, we can use the ESR approach developed by Hill and MacRae (1995), updated and adapted to crop protection (DeLonge et al. 2016; Hill 2004 and 2014; Hill et al. 1999). Replacing conventional chemical control (Integrated Pesticide Management) is not a simple question of improving its efficiency (E) or substituting it with other methods (S), including biological control, in a curative approach. The objective is to apply truly profound preventive ecological solutions (Hill 2004), by redesigning (R) cropping systems, even if some authors advocate modification of crop succession as an essential element of crop control in IPM strategies (Bajwa and Kogan 2004; Palti 1981). This alternative can make use of biological control, especially conservation biological control, which significantly contributes to restoring agroecosystems regulation (Wyckhuys et al. 2013).

However, a broader issue is the redesign of socio-technical systems, from field to market, within food systems (Hoy et al. 2016). In the momentum of food system development, Hill (2004 and 2014) underlines the need to consider social ecology, as defined by Huxley (1964), in addition to organic and agronomic ecology. This is confirmed by DeLonge et al. (2016) in order to facilitate the transition to sustainable food systems.

In this redesign, crop protection is only one component, and it is subdivided into two stages: i) deconstruction of the pesticide-based pest management plan and ii) introduction of a new management scheme for the agroecosystem, consistent over the entire food system, and focusing on biological, agronomic and social ecology. The objective is the creation of healthy ecosystems and productive, sustainable, fair and resilient agroecosystems (Hoy 2015), based on optimized interactions between plant, animal and microbial communities, which contribute to crop health (Vega et al. 2020). As a consequence, the large reduction in pesticide use observed in fullscale experiments (Deguine et al. 2015 and 2018) is no longer seen as an objective, but simply as a positive effect of a healthy agroecosystem. Finally, healthy agroecosystems intentionally safeguard the ecological resilience of farming systems and are a core constituent of sustainable food systems (Hamm 2009; Hoy et al. 2016).

Acknowledgements We thank Philippe Lucas and Pierre Ferron, who encouraged us to carry out this review and who supported us in our reflections. We also thank Antoine Frank (CIRAD) and Christophe 
Maitre (INRAE) for allowing us to use the photos (respectively Figs. 1 and 2). Thanks also to our colleagues Jérémy Bouyer (CIRAD), Eric Justes (CIRAD), and Olivier Dangles (IRD) who kindly reread the manuscript before its submission. In addition, we would like to thank the Managing Editor of Agronomy for Sustainable Development and the four anonymous reviewers for their comments which helped us improve this manuscript.

Code availability Not applicable.

Author contribution Conceptualization, J.-P.D. and A.R.; Methodology, J.-P.D., J.-N.A., R.J.F., F.L., K.W., A.R.; Investigation, J.-P.D., R.J.F., A.R.; Writing - Original draft, J.-P.D., R.J.F., A.R.; Review and Editing, J.-P.D., J.-N.A., F.L., K.W.; Funding acquisition, J.-P.D., J.-N.A.; Resources : J.-P.D., J.-N.A., A.R.; Supervision, J.-P.D., K.W., A.R.

Data availability All the data used to write this bibliographic review come from the publications listed in the reference list below.

\section{Declarations}

Ethics approval The authors approve.

Consent to participate The authors consent to participate.

Consent for publication The authors consent for publication.

Competing interests The authors declare no competing interests.

Open Access This article is licensed under a Creative Commons Attribution 4.0 International License, which permits use, sharing, adaptation, distribution and reproduction in any medium or format, as long as you give appropriate credit to the original author(s) and the source, provide a link to the Creative Commons licence, and indicate if changes were made. The images or other third party material in this article are included in the article's Creative Commons licence, unless indicated otherwise in a credit line to the material. If material is not included in the article's Creative Commons licence and your intended use is not permitted by statutory regulation or exceeds the permitted use, you will need to obtain permission directly from the copyright holder. To view a copy of this licence, visit http://creativecommons.org/licenses/by/4.0/.

\section{References}

Abate T, van Huis A, Ampofo JKO (2000) Pest management strategies in traditional agriculture: an African perspective. Annu Rev Entomol Annual 45:631-659. https://doi.org/10.1146/annurev.ento.45.1.631

Abrol DP (2014) Integrated Pest Management: Current Concepts and Ecological Perspective. Academic Press, San Diego

Abrol DP, Shankar U (2012) Integrated pest management: Principles and practice. CABI, Wallingford

Ahmed KS, Majeed MZ, Haidary AA, Haider N (2016) Integrated pest management tactics and predatory coccinellids: A review. J Entomol Zool Stud 4:591-600

Altieri MA (1980) The need for an agroecological approach to pest management. Environ Manage 4:467-468

Altieri MA (1989) Agroecology: A new research and development paradigm for world agriculture. Agric Ecosyst Environ 27:37-46. https://doi.org/10.1016/0167-8809(89)90070-4
Altieri MA (1995) Agroecology: The Science of Sustainable Agriculture. Westview Press, Boulder

Altieri MA (2004) Linking ecologists and traditional farmers in the search for sustainable agriculture. Front Ecol Environ 2:35-42. https://doi. org/10.1890/1540-9295(2004)002[0035:LEATFI]2.0.CO;2

Altieri MA, Martin PB, Lewis WJ (1983) A quest for ecologically based pest management systems. Environ Manage 7:91-99. https://doi. org/10.1007/BF01867047

Altieri MA, Nicholls CI (2003) Ecologically based pest management: a key pathway to achieving agroecosystem health. In: Managing for Healthy Ecosystems. CRC Press, Boca Raton, pp 993-1004

Altieri MA, Nicholls CI (2004) Biodiversity and Pest Management in Agroecosystems. The Haworth Press, New York

Altieri MA, Nicholls CI (2017) Agroecological foundations for pest management in the tropics: learning from traditional farmers. In: Integrated Pest Management in Tropical Regions. CABI, Wallingford, pp 6-17

Alwang J, Norton G, Larochelle C (2019) Obstacles to widespread diffusion of IPM in developing countries: Lessons from the field. J Integr Pest Manage 10:10. https://doi.org/10.1093/jipm/pmz008

Anderson JR, Feder G (2004) Agricultural Extension: good Intentions and hard Realities. World Bank Res Obs 19:41-60. https://doi.org/ 10.1093/wbro/lkh013

Andrews KL, Bentley JW, Cave RD (1992) Enhancing biological control's contributions to integrated pest management through appropriate levels of farmer participation. Fla Entomol 75:429-439. https:// doi.org/10.2307/3496124

Aubertot J-N, Barbier J-M, Carpentier A, Gril J-J, Guichard L, Lucas P, Voltz M (eds) (2005) Pesticides, agriculture et environnement. Réduire l'utilisation des pesticides et en limiterles impacts environnementaux. Quae, Versailles

Aubertot J-N, Robin M-H (2013) Injury Profile SIMulator, a qualitative aggregative modelling framework to predict crop injury profile as a function of cropping practices, and the abiotic and biotic environment. I. Conceptual bases. PloS One 8:e73202. https://doi.org/10. 1371/journal.pone.0073202

Bagavathiannan MV, Graham S, Ma Z, Barney JN, Coutts SR, Caicedo AL, De Clerck-Floate R, West NM, Blank L, Metcalf AL, Lacoste M, Moreno CR, Evans JA, Burke I, Beckie H (2019) Considering weed management as a social dilemma bridges individual and collective interests. Nat plants 5:343-351. https://doi.org/10.1038/ s41477-019-0395-y

Bajwa WI, Kogan M (2002) Compendium of IPM Definitions (CID). What is IPM and how is it defined in the Worldwide Literature? Integrated Plant Protection Center (IPPC). Oregon State University, Corvallis. Publication Number 998

Bajwa WI, Kogan M (2004) Cultural practices: springboard to IPM. In: Integrated Pest Management: potential, constraints and challenges. CABI, Wallinford, pp. 21-38

Baker BP, Green TA, Loker AJ (2020) Biological control and integrated pest management in organic and conventional systems. Biol Control 140:104095. https://doi.org/10.1016/j.biocontrol.2019.104095

Bakker T, Dugué P, de Tourdonnet S (2021) Assessing the effects of farmer field schools on farmers' trajectories of change in practices. Agron Sustain Dev 41:1-15. https://doi.org/10.1007/s13593-02100667-2

Baldi I, Bouvier G, Cordier S, Coumoul X, Elbaz A, Gamet-Payrastre L, Lebailly P, Multigner L, Rahmani R, Spinosi J, van Maele-Fabry G (2013) Pesticides. Effets sur la santé. Synthèse et recommandations. Expertise collective. INSERM, Paris

Barbier EB (1987) The concept of sustainable economic development. Environ Conserv 14:101-110. https://doi.org/10.1017/ S0376892900011449

Barratt BIP, Moran VC, Bigler F, van Lenteren JC (2018) The status of biological control and recommendations for improving uptake for 
the future. Biol Control 63:155-167. https://doi.org/10.1007/ s10526-017-9831-y

Barducci TB (1972) Ecological consequences of pesticides used for the control of cotton insects in Canete Valley, Peru. In: The Careless Technology: Ecology and international development. The Natural History Press, Garden City, pp 423-438

Barrera JF (2020a) Holistic Pest Management. In: Aera-wide management of fruit fly pests CRC Press, Boca Raton, pp. 275-293

Barrera JF (2020b) Introduction: Beyond IPM. In: Beyond IPM: Introduction to the Theory of Holistic Pest Management. Sustainability in Plant and Crop Protection. Springer, pp. 1-8

Barzman M, Bàrberi P, Birch ANE, Boonekamp P, Dachbrodt-Saaydeh S, Graf B, Hommel B, Jensen JE, Kiss J, Kudsk P, Lamichhane JR, Messéan A, Moonen AC, Ratnadass A, Ricci P, Sarah JL, Sattin M (2015) Eight principles of integrated pest management. Agron Sustain Dev 35:1199-1215. https://doi.org/10.1007/s13593-0150327-9

Barzman MS, Bertschinger L, Dachbrodt-Saaydeh S, Graf B, Jensen JE, Jorgensen LN, Kudsk P, Messéan A, Moonen AC, Ratnadass A, Sarah JL, Sattin M (2014) IPM policy, research and implementation: European initiatives. In: Peshin R, Pimentel D (eds) Integrated Pest Management, Experiences with Implementation, Global Overview 4. Springer, London, pp 415-428

Bassil KL, Vakil C, Sanborn M, Cole DC, Kaur JS, Kerr KJ (2007) Cancer health effects of pesticides: systematic review. Can Fam Physician 53:1704-1711

Beddington J (2010) Food security: contributions from science to a new and greener revolution. Philos T R Soc B 365:61-71. https://doi.org/ 10.1098/rstb.2009.0201

Begg GS, Cook SM, Dye R, Ferrante M, Franck P, Lavigne C, Lovei GL, Mansion-Vaquie A, Pell JK, Petit S, Quesada N, Ricci B, Wratten SD, Birch ANE (2017) A functional overview of conservation biological control. Crop Prot 97:145-158. https://doi.org/10.1016/j. cropro.2016.11.008

Bellon S, de Sainte MC, Lauri PE, Navarette M, Nesme T, Plénet D, Pluvinage J, Habib R (2006) La production fruitière intégrée : le vert est-il dans le fruit ? Le Courrier de l'Environnement de l'INRA, Paris, pp 5-18 https://hal.inrae.fr/hal-02656625

Benbrook CM (1996) Pest management at Crossroads. Consumers Union, Yonkers

Bentley JW (1989) What farmers don't know can't help them: The strengths and weaknesses of indigenous technical knowledge in Honduras. Agric Hum Values 6:25-31. https://doi.org/10.1007/ BF02217666

Bentley JW, Boa, van Mele P, Almanza J, Vasquez D, Eguino S (2003) Going public: a new extension method. Int J Agric Sustain 1:108123. https://doi.org/10.3763/ijas.2003.0111

Bernhardt ES, Rosi EJ, Gessner MO (2017) Synthetic chemicals as agents of global change. Front Ecol Environ 15:84-90. https://doi.org/10. $1002 /$ fee. 1450

Bianchi FJJA, Booij CJH, Tscharntke T (2006) Sustainable pest regulation in agricultural landscapes: a review on landscape composition, biodiversity and natural pest control. P R Soc B-Biol Sci 273:17151727. https://doi.org/10.1098/rspb.2006.3530

Birch ANE, Begg GS, Squire GR (2011) How agro-ecological research helps to address food security issues under new IPM and pesticide reduction policies for global crop production systems. J Exp Bot 62: 3251-3261. https://doi.org/10.1093/jxb/err064

Boisclair J, Estevez B (2006) Insect pest management in organic agriculture: acting in harmony with complexity. Phytoprotection 87:83-90

Boller EF, Avilla J, Joerg E, Malavolta C, Wijnands FG, Esbjerg P (2004) Integrated Production. Principles and Technical Guidelines, 3rd edition. IOBC/WPRS Bull 27

Bommarco R, Kleijn D, Potts SG (2013) Ecological intensification: harnessing ecosystem services for food security. Trends Ecol Evol 28:230-238. https://doi.org/10.1016/j.tree.2012.10.012
Bonny S (1997) L'agriculture raisonnée, l'agriculture intégrée et FarreForum de l'agriculture raisonnée respectueuse de l'environnement. Natures Sciences Sociétés 5:64-71

Bottrell DG (1996) The Research Challenge for Integrated Pest Management in Developing Countries: A Perspective for Rice in Southeast Asial. J Agric Entomol 13:185-193

Bottrell DR, Bottrell DG (1979) Integrated pest management. Council on Environmental Quality. Washington, DC

Bottrell DG, Schoenly KG (2012) Resurrecting the ghost of green revolutions past: the brown planthopper as a recurring threat to highyielding rice production in tropical Asia. J Asia-Pac Entomol 15: $122-140$

Bourguet D, Guillemaud T (2016) The hidden and external costs of pesticide use. Sustain Agric Rev 19:35-120. https://doi.org/10.1007/ 978-3-319-26777-7 2

Brévault T, Bouyer J (2014) From integrated to system-wide pest management: Challenges for sustainable agriculture. Outlooks Pest Manage 25:212-213. https://doi.org/10.1564/v25 jun 05

Brévault T, Renou A, Vayssieres J-F, Amadji G, Assogba-Komlan F, Diallo M-D, De Bon H, Diarra K, Hamadoun A, Huat J, Marnotte P, Menozzi P, Prudent P, Rey J-Y, Sall D, Silvie P, Simon S, Sinzogan A, Soti V, Tamòo M, Clouvel P (2014) DIVECOSYS: Bringing together researchers to design ecologically-based pest management for small-scale farming systems in West Africa. Crop Prot 66:53-60. https://doi.org/10.1016/j.cropro.2014.08.017

Brewer MJ, Goodell PB (2012) Approaches and incentives to implement integrated pest management that addresses regional and environmental issues. Annu Rev Entomol 57:41-59. https://doi.org/10. 1146/annurev-ento-120709-144748

Brzozowski L, Mazourek MA (2018) Sustainable Agricultural Future Relies on the Transition to Organic Agroecological Pest Management. Sustainability-Basel 10:2023. https://doi.org/10. 3390/su10062023

Buckwell A, De Wachter E, Nadeu E, Williams A (2020) Crop Protection $\&$ the EU Food System. Where are they going? RISE Foundation, Brussels

Burdon FJ, Munz NA, Reyes M, Focks A, Joss A, Rasanen K, Altermatt F, Eggen RIL, Stamm C (2019) Agriculture versus wastewater pollution as drivers of macroinvertebrate community structure in streams. Sci Total Environ 659:1256-1265. https://doi.org/10. 1016/j.scitotenv.2018.12.372

Byerlee D, de Janvry A, Sadoulet E (2009) Agriculture for Development: Toward a New Paradigm. Annu Rev of Resour Econ 1:15-31. https://doi.org/10.1146/annurev.resource.050708.144239

Calo A (2018) How knowledge deficit interventions fail to resolve beginning farmer challenges. Agr Hum Values 35:367-381. https://doi. org/10.1007/s10460-017-9832-6

Capinera JL (2014) Integrated Pest Management: Current Concepts and Ecological Perspective. Fla Entomol 97:1272. https://doi.org/10. 1653/024.097.0342

Caron P, Biénabe E, Hainzelin E (2014) Making transition towards ecological intensification of agriculture a reality: the gaps in and the role of scientific knowledge. Curr Opin Env Sust 8:44-52. https://doi. org/10.1016/j.cosust.2014.08.004

Carson R (1962) Silent spring. The Riverside Press, Cambridge

Castella J-C, Jourdain D, Trebuil G, Napompeth B (1999) A systems approach to understanding obstacles to effective implementation of IPM in Thailand: key issues for the cotton industry. Agr Ecosyst Environ 72:17-34. https://doi.org/10.1016/S0167-8809(98)00159-5

Chaplin-Kramer R, O'Rourke M, Zhang W, Robinson B, Schellhorn N, Gratton C, Rosenheim JA, Tscharntke T, Karp DS (2019) Measuring what matters: actionable information for conservation biocontrol in multifunctional landscapes. Front Sustain Food Syst 3:60. https://doi.org/10.3389/fsufs.2019.00060

CAVAC (2014) CAVAC (Cambodia Agricultural Value Chain Program) Six-Monthly Report. CAVAC, Phnom Penh 
Chamberlain DE, Fuller RJ (2000) Local extinctions and changes in species richness of lowland farmland birds in England and Wales in relation to recent changes in agricultural land-use. Agr Ecosyst Environ 78:1-17. https://doi.org/10.1016/S0167-8809(99)00105-X

Coll M, Wajnberg E (2017a) Environmental pest management: Challenges for agronomists, ecologists, economists and policymakers. John Wiley \& Sons, Chichester

Coll M, Wajnberg E (2017b) Environmental Pest Management: A Call to Shift from a Pest-Centric to a System-Centric Approach. In: Environmental pest management: challenges for agronomists, ecologists, economists and policymakers. John Wiley \& Sons, Chichester, UK, pp 1-17

Conway G (1997) The Double Green Revolution. Penguin Books, London, UK

Conway G (1999) The Doubly Green Revolution: Food for All in the Twenty-first Century. Cornell University Press, Ithaca, New York

Conway G, Wilson K, Wilson E (2013) Un rapport du Panel de Montpellier 2013, L'intensification durable : un nouveau paradigme pour l'agriculture africaine. Agriculture for Impact, Imperial College, London

Corbet PS (1981) Non-entomological impediments to the adoption of integrated pest management. Prot Eco 3:183-202

Cowan R, Gunby P (1996) Sprayed to death: path dependence, lock-in and pest control strategies. Econ J 106:521-542. https://doi.org/10. 2307/2235561

Dáder B, Colomer I, Adán Á, Medina P, Viñuela E (2020) Compatibility of early natural enemy introductions in commercial pepper and tomato greenhouses with repeated pesticide applications. Insect Sci 27:1111-1124. https://doi.org/10.1111/1744-7917.12723

Dainese M, Martin EA, Aizen MA, Albrecht M, Bartomeus I, Bommarco R, Carvalheiro LG, Chaplin-Kramer R, Gagic V, Garibaldi LA, Ghazoul J, Grab H, Jonsson M, Karp DS, Kennedy CM, Kleijn D, Kremen C, Landis DA, Letourneau DK, Marini L, Poveda K, Rader R, Smith HG, Tscharntke T, Andersson GKS, Badenhausser I, Baensch S, Bezerra ADM, Bianchi FJJA, Boreux V, Bretagnolle V, Caballero-Lopez B, Cavigliasso P, Ćetković A, Chacoff NP, Classen A, Cusser S, da Silva e Silva FD, de Groot GA, Dudenhöffer JH, Ekroos J, Fijen T, Franck P, Freitas BM, Garratt MPD, Gratton C, Hipólito J, Holzschuh A, Hunt L, Iverson AL, Jha S, Keasar T, Kim TN, Kishinevsky M, Klatt BK, Klein A-M, Krewenka KM, Krishnan S, Larsen AE, Lavigne C, Liere H, Maas B, Mallinger RE, Martinez Pachon E, Martínez-Salinas A, Meehan TD, Mitchell MGE, Molina GAR, Nesper M, Nilsson L, O'Rourke ME, Peters MK, Plećaš M, Potts SG, de L. Ramos D, Rosenheim JA, Rundlöf M, Rusch A, Sáez A, Scheper J, Schleuning M, Schmack JM, Sciligo AR, Seymour C, Stanley DA, Stewart R, Stout JC, Sutter L, Takada MB, Taki H, Tamburini G, Tschumi M, Viana BF, Westphal C, Willcox BK, Wratten SD, Yoshioka A, Zaragoza-Trello C, Zhang W, Zou Y, Steffan-Dewenter I (2019) A global synthesis reveals biodiversity-mediated benefits for crop production. Sci Adv 5:eaax0121. https://doi.org/10.1126/sciadv. aax0121

Dalgaard T, Hutchings NJ, Porter JR (2003) Agroecology, scaling and interdisciplinarity. Agr Ecosyst Environ 100:39-51. https://doi.org/ 10.1016/S0167-8809(03)00152-X

Dangles O, Casas J (2019) Ecosystem services provided by insects for achieving sustainable development goals. Ecosyst Serv 35:109-115. https://doi.org/10.1016/j.ecoser.2018.12.002

Dangles O, Crespo-Pérez V (2020) Editorial overview: Devastating locust swarms and pandemics: the same pressing need for sustainability. Curr Opin Insect Sci 40:v-ix. https://doi.org/10.1016/j.cois. 2020.08.004

Dara SK (2019) The new integrated pest management paradigm for the modern age. J Integrat Pest Manage 10:1-9. https://doi.org/10.1093/ jipm/pmz010
Dasgupta P (2007) The idea of sustainable development. Sustain Sci 2:511. https://doi.org/10.1007/s11625-007-0024-y

De Bach P (1974) Biological control by natural enemies. Cambridge University Press, London

Deberdt P, Fernandes P (2017) Agroecological Management of Bacterial Wilt of Tomato in Martinique. In: Agroecological Crop Protection. Springer Science+Business Media BV, Dordrecht

Deguine J-P, Atiama-Nurbel T, Aubertot J-N, Augusseau X, Atiama M, Jacquot M, Reynaud B (2015) Agroecological management of cucurbit-infesting fruit fly: a review. Agro Sustain Dev 35:937965. https://doi.org/10.1007/s13593-015-0290-5

Deguine J-P, Aubertot J-N, de Cambiaire J-C, Cresson C, Fares M, Lambert G, Marquier M, Nurbel T, Laurent P, Vanhuffel L, Vincenot D (2019) Development of agroecological horticultural systems in Réunion. In: The agroecological transition of agricultural systems in the Global South, Agricultures et défis du monde collection, AFD, CIRAD, Éditions Quæ, Versailles, pp. 127-140

Deguine J-P, Ferron P, Russell D (2008) Sustainable pest management for cotton production. A review. Agron Sustain Dev 28:113-137. https://doi.org/10.1051/agro:2007042

Deguine J-P, Ferron P, Russell D (2009) Crop Protection: from Agrochemistry to Agroecology. Science Publishers, Enfield, NH, USA

Deguine J-P, Gloanec C, Laurent P, Ratnadass A, Aubertot J-N (2017) Agroecological Crop Protection. Springer Science+Business Media $\mathrm{BV}$, Dordrecht

Deguine J-P, Gozé E, Leclant F (2000) The consequences of late outbreaks of the aphids Aphis gossypii in cotton growing in Central Africa: towards a possible method for the prevention of cotton stickiness. Int J Pest Manage 46:85-89. https://doi.org/10.1080/ 096708700227426

Deguine J-P, Gozé E, Leclant F (1994) Incidence of early outbreaks of the aphid Aphis gossypii Glover in cotton growing in Cameroon. Int J Pest Manage 40:132-140. https://doi.org/10.1080/ 09670879409371870

Deguine J-P, Jacquot M, Allibert A, Chiroleu F, Graindorge R, Laurent P, Albon B, Marquier M, Gloanec C, Lambert G, Vanhuffel L, Vincenot D, Aubertot J-N (2018) Agroecological Protection of Mango Orchards in Réunion. Sustain Agr Rev 28:249-308. https://doi.org/10.1007/978-3-319-90309-5_8

Deguine J-P, Penvern S (2014) Agroecological Crop Protection in Organic Farming: Relevance and Limits. In: Organic Farming, Prototype for Sustainable Agricultures, (C) Springer Science+ Business Media Dordrecht, pp. 107-130

Deguine J-P, Ratnadass A (2017) Agroecogical Crop Protection: At the Interface Between Agroecology, Crop Protection and Biodiversity Management. In: Agroecological Crop Protection. Springer Science+Business Media BV, Dordrecht, pp. 33-43

Deguine J-P, Robin M-H, Corrales DC et al (2021) Qualitative modeling of fruit fly injuries on chayote in Réunion: Development and transfer to users. Crop Prot 139:105367. https://doi.org/10.1016/j.cropro. 2020.105367

DeLonge MS, Miles A, Carlisle L (2016) Investing in the transition to sustainable agriculture. Environ Sci Policy 55:266-273. https://doi. org/10.1016/j.envsci.2015.09.013

Demestihas C, Plénet D, Génard M, Raynal C, Lescourret F (2017) Ecosystem services in orchards. A review. Agron Sustain Dev 37: 12. https://doi.org/10.1007/s13593-017-0422-1

Dent DR (1995) Integrated pest management. Chapman \& Hall, London de Schutter O, Vanloqueren G (2011) The new green revolution: how twenty-first-century science can feed the world. Solutions 2:33-44 http://hdl.handle.net/10535/7482

Despotović J, Rodić V, Caracciolo F (2019) Factors affecting farmers' adoption of integrated pest management in Serbia: An application of the theory of planned behavior. J Clean Prod 228:1196-1205. https://doi.org/10.1016/j.jclepro.2019.04.149 
Deytieux V, Munier-Jolain N, Caneill J (2015) Assessing the sustainability of cropping systems in single- and multi-site studies. A review of methods. Eur J Agron 72:107-126. https://doi.org/10.1016/j.eja. 2015.10.005

DiBartolomeis M, Kegley S, Mineau P, Radford R, Klein K (2019) An assessment of acute insecticide toxicity loading (AITL) of chemical pesticides used on agricultural land in the United States. PloS One 14:e0220029. https://doi.org/10.1371/journal.pone.0220029

Doré T, Makowski D, Malézieux E, Munier-Jolain N, Tchamitchian M, Tittonell P (2011) Facing up to the paradigm of ecological intensification in agronomy: Revisiting methods, concepts and knowledge. Eur J Agron 34:197-210. https://doi.org/10.1016/j.eja.2011.02.006

Dupré M, Michels T, Le Gal PY (2017) Diverse dynamics in agroecological transitions on fruit tree farms. Eur J Agron 90:23-33. https:// doi.org/10.1016/j.eja.2017.07.002

Duru M, Therond O, Martin G, Martin-Clouaire R, Magne MA, Justes E, Journet EP, Aubertot J-N, Savary S, Bergez JE, Sarthou J-P (2015) How to implement biodiversity-based agriculture to enhance ecosystem services: A review. Agron Sustain Dev 35:1259-1281. https://doi.org/10.1007/s13593-015-0306-1

Dufour R (2001) Biointensive Integrated Pest Management (IPM). Fundamentals Sustain Agr 522:2-12

Eddleston M, Karalliedde L, Buckley N, Fernando R, Hutchinson G, Isbister G, Konradsen F, Murray D, Piola JC, Senanayake N, Sherriff R, Singh, Siwach SB, Smit L (2002) Pesticide poisoning in the developing world-a minimum pesticides list. Lancet 360: 1163-1167. https://doi.org/10.1016/S0140-6736(02)11204-9

Egan PA, Dicks LV, Hokkanen HM, Stenberg JA (2020) Delivering Integrated Pest and Pollinator Management (IPPM). Trends Plant Sci 25:577-589. https://doi.org/10.1016/j.tplants.2020.01.006

Ehler LE (2005) Integrated pest management: a national goal? Issues Sci Technol 22:25-26

Ehler LE (2006) Integrated pest management (IPM) definition, historical development and implementation, and the other IPM. Pest Manage Sci 62:787-789

Ehler LE, Bottrell DG (2000) The illusion of Integrated Pest Management. Issues Sci Technol 16:61-64. https://doi.org/10. 2307/43312037

El Titi A, Boller EB, Gendrier J-P (1993) Integrated production. Principles and Technical Guidelines, 3rd edition. IOBC/WPRS Bull 16

Enkerlin W, Gutiérrez-Ruelas JM, Cortes AV, Roldan EC, Midgarden D, Lira E, López JLZ, Hendrichs J, Liedo P, Arriaga FJT (2015) Area freedom in Mexico from Mediterranean fruit fly (Diptera: Tephritidae): a review of over 30 years of a successful containment program using an integrated area-wide SIT approach. Fla Entomol 98:665-681. https://doi.org/10.1653/024.098.0242

Enserink M, Hines PJ, Vignieri SN, Wigginton NS, Yeston JS (2013) The pesticide paradox. Science 341:728-729. https://doi.org/10.1126/ science.341.6147.728

Epstein L, Bassein S (2003) Patterns of pesticide use in California and the implications for strategies for reduction of pesticides. Annu Rev Phytopathol 41:351-375. https://doi.org/10.1146/annurev.phyto. 41.052002 .095612

Epstein L, Zhang M (2014) The Impact of Integrated Pest Management Programs on Pesticide Use in California, USA. In: Integrated Pest Management. Springer, Dordrecht. pp. 1-46

European Commission (2020) A farm to fork strategy for a fair, healthy and environmentally-friendly food system. Communication from the Commission to the European Parliament, the Council, the European Economic and Social Committee, and the Committee of the Regions. COM(2020) 381 final. https://ec.europa.eu/info/sites/ info/files/communication-annex-farm-fork-greendeal_en.pdf.

Faloya V, Jeannequin B (2017) Agroecological practices to manage soilborne pathogens in greenhouse vegetable crops in France. In:
Agroecological Crop Protection. Springer Science+Business Media B.V., Dordrecht, pp. 112-119

FAO (2020) NSP - Integrated Pest Management, FAO definition. http:// www.fao.org/agriculture/crops/thematic-sitemap/theme/pests/ipm/ en/.

Fantke P, Friedrich R, Jolliet O (2012) Health impact and cost damage assessment of pesticides in Europe. Environ Int 49:9-17. https://doi. org/10.1016/j.envint.2012.08.001

Farrar JJ, Ellsworth PC, Sisco R, Baur ME, Crump A, Fournier AJ, Murray MK, Jepson PC, Tarutani CM, Dorschner KW (2018) Assessing Compatibility of a Pesticide in an IPM Program. J Integr Pest Manage 9:1-6. https://doi.org/10.1093/jipm/pmx032

Feder G, Murgai R, Quizon JB (2004) The acquisition and diffusion of knowledge: The case of pest management training in farmer field schools, Indonesia. J Agr Econ 55:221-243. https://doi.org/10. 1111/j.1477-9552.2004.tb00094.x

Fernandez-Cornejo J, Kackmeister A (1996) The diffusion of integrated pest management techniques. J Sustain Agr 7:71-102

Ferron P (1999) Protection intégrée des cultures : évolution du concept et de son application. Cah Agr 8:389-396

Ferron P, Deguine J-P (2005) Crop protection, biological control, habitat management and integrated farming. Agr Sustain Dev 25:17-24

Filho FH, Heldens WB, Kong Z, de Lange ES (2020) Drones: innovative technology for use in precision pest management. J Econ Entomol 113:1-25. https://doi.org/10.1093/jee/toz268

Flor RJ, Chhay K, Sorn V, Maat H, Hadi BAR (2018) The technological trajectory of Integrated Pest Management for rice in Cambodia. Sustainability-Basel 10:1-14. https://doi.org/10.3390/su10061732

Flor RJ, Maat H, Hadi BAR, Then R, Kraus E, Chhay K (2020) How do stakeholder interactions in Cambodian rice farming villages contribute to a pesticide lock-in? Crop Prot 135:104799. https://doi.org/10. 1016/j.cropro.2019.04.023

Flöhr A, Stenberg JA, Egan PA (2018) The joint economic impact level (jEIL): a decision metric for integrated pest and pollinator management. In: Integrative Biological Control. Progress in Biological Control, vol 20. Springer, Cham. https://doi.org/10.1007/978-3030-44838-7 2

Foucart S (2019) Et le monde devint silencieux. Comment l'agrochimie a détruit les insectes, Seuil, Paris

Frisbie RE, Smith JW Jr (1991) Biologically intensive integrated pest management: the future. In: Progress and Perspectives for the 21th Century. Entomol. Soc. Am. Centennial Symp. ESA, Lanham, MD, USA, pp 151-164

Frison EA, Gold CS, Karamura EB, Sikora RA (1999) Mobilizing IPM for sustainable banana production in Africa. Proceedings of a workshop on banana IPM held in Nelspruit, South Africa-23-28 November 1998. International Network for the Improvement of Banana and Plantain (INIBAP), Montpellier, France

Gaba S, Lescourret F, Boudsocq S, Enjalbert J, Hinsinger P, Journet EP, Navas ML, Wery J, Louarn G, Malézieux E, Pelzer E, Prudent M, Ozier-Lafontaine H (2015) Multiple cropping systems as drivers for providing multiple ecosystem services: from concepts to design. Agron Sustain Dev 35:607-623. https://doi.org/10.1007/s13593014-0272-z

Gandini G, Guillermet C, de Lapeyre de Bellaire L (2017) Agroecological Management of Banana Pests in Export Crops in the Dominican Republic. In: Agroecological Crop Protection. Springer Science+Business Media B.V., Dordrecht, pp. 135-141

Garcia K, Olimpi EM, Karp DS, Gonthier DJ (2020) The Good, the Bad, and the Risky: Can Birds Be Incorporated as Biological Control Agents into Integrated Pest Management Programs? J Integr Pest Manage 11:11. https://doi.org/10.1093/jipm/pmaa009

Geertsema W, Rossing WA, Landis DA, Bianchi FJJA, van Rijn PC, Schaminée JH, Tscharntke T, van Der Werf W (2016) Actionable knowledge for ecological intensification of agriculture. Front Ecol Environ 14:209-216. https://doi.org/10.1002/fee.1258 
Geiger F, Bengtsson J, Berendse F, Weisser WW, Emmerson M, Morales MB, Ceryngier P, Liira J, Tscharntke T, Winqvist C, Eggers S, Bommarco R, Pärt T, Bretagnolle V, Plantegenest M, Clement LW, Dennis C, Palmer C, Oñate JJ, Guerrero I, Hawro V, Aavik T, Thies C, Flohre A, Hänke S, Fischer C, Goedhart PW, Inchausti P (2010) Persistent negative effects of pesticides on biodiversity and biological control potential on European farmland. Basic Appl Ecol 11:97-105. https://doi.org/10.1016/j.baae.2009.12.001

Gliessman SR (1997) Agroecology: Ecological Processes in Sustainable Agriculture. CRC press, Boca Raton, USA

Gliessman SR (2016) Transforming food systems with agroecology. Agroecol Sust Food 40:187-189. https://doi.org/10.1080/ 21683565.2015.1130765

González-Chang M, Wratten SD, Shields MW, Costanza R, Dainese M, Gurr GM, Johnson J, Karp DS, Ketelaar JW, Nboyine J, Pretty J (2020) Understanding the pathways from biodiversity to agroecological outcomes: A new, interactive approach. Agr Ecosyst Environ 301:107053. https://doi.org/10.1016/j.agee.2020.107053

Goodell GE (1984) Challenges to International Pest Management Research and Extension in the Third World: Do We Really Want IPM to Work? Bull Entomol Soc Amer 30:8-26. https://doi.org/10. 1093/besa/30.3.18

Goodell GE (1989) Social science input into IPM. Trop Pest Manage 35: 252-253

Goss MJ, Barry DAJ (1995) Groundwater Quality: Responsible Agriculture and Public Perceptions. J Agr Environ Ethic 8:52-64. https://doi.org/10.1007/BF02286401

Goulson D (2020) Pesticides, Corporate Irresponsibility, and the Fate of Our Planet. One Earth 2:302-305. https://doi.org/10.1016/j.oneear. 2020.03.004

Griffon M (2013) Qu'est-ce que l'agriculture écologiquement intensive? Editions Quae, Versailles

Guedes RNC, Smagghe G, Stark JD, Desneux N (2016) Pesticideinduced stress in arthropod pests for optimized integrated pest management programs. Annu Rev Entomol 61:43-62. https://doi.org/ 10.1146/annurev-ento-010715-023646

Guichard L, Dedieu F, Jeuffrou M-H, Meynard J-M, Reau R, Savini I (2017) Le plan Ecophyto de réduction d'usage des pesticides en France : décryptage d'un échec et raisons d'epérer. Cah Agr 26: 14002. https://doi.org/10.1051/cagri/2017004

Gurr GM, Wratten SD, Landis DA, You M (2017) Habitat management to suppress pest populations: progress and prospects. Annu Rev Entomol 62:91-109. https://doi.org/10.1146/annurev-ento-031616035050

Haldhar SM, Choudhary BR, Bhargava R, Sharma SK (2014) Development of an organic integrated pest management (IPM) module against insect-pests of muskmelon in arid region of Rajasthan, India. J Exp Biol Agr Sci 2:19-24 https://krishi.icar.gov.in/jspui/ bitstream/123456789/2248/1/IPM\%20Modules\%20in\% 20Muskmelon.pdf

Hallmann CA, Foppen RPB, van Turnhout CAM, de Kroon H, Jongejans E (2014) Declines in insectivorous birds are associated with high neonicotinoid concentrations. Nature 511:341-343. https://doi.org/ 10.1038 /nature 13531

Hallmann CA, Sorg M, Jongejans E, Siepel H, Hofland N, Schwan H, Stenmans W, Müller A, Sumser H, Hörren T, Goulson D, de Kroon $\mathrm{H}$ (2017) More than 75 percent decline over 27 years in total flying insect biomass in protected areas. Plos One 12:e0185809. https:// doi.org/10.1371/journal.pone.0185809

Hamm MW (2009) Principles for Framing a Healthy Food System. J Hung Environ Nutr 4:241-250. https://doi.org/10.1080/ 19320240903321219

Hammig MD, Shepard BM, Carner GR, Dilts R, Rauf A (2008) Areawide pest management for non-rice food crops in Southeast Asia. Area-wide Pest Management: Theory and Implementation. CABI, Wallingford, pp 326-350
Hedlund J, Longo SB, York R (2020) Agriculture, Pesticide Use, and Economic Development: A Global Examination (1990-2014). Rural Sociol 85:519-544. https://doi.org/10.1111/ruso.12303

Heinrichs EA, Maredia KM, Mohankumar S (2009) Future of IPM: a worldwide perspective. In: Integrated pest management. Concepts, tactics, strategies and case studies. Cambridge University Press, pp. $506-522$

Heong KL, Escalada MM (1997) Perception change in rice pest management: A case study of farmers' evaluation of conflict information. J Appl Commun 82:3-17

Heong KL, Escalada MM (1999) Quantifying rice farmers' pest management decisions: beliefs and subjective norms in stem borer control. Crop Prot 18:315-322. https://doi.org/10.1016/S0261-2194(99) 00030-7

Hill SB (2004) Redesigning Pest Management. J Crop Improv 12:491510. https://doi.org/10.1300/J411v12n01_09

Hill SB (2014) Considerations for Enabling the Ecological Redesign of Organic and Conventional Agriculture: A Socail Ecology and Psychosocial Perspective. In: Organic Farming, Prototype for Sustainable Agricultures. Springer Science+Business Media Dordrecht, pp. 401-422

Hill SB, MacRae RJ (1995) Conceptual Framework for the Transition from Conventional to Sustainable Agriculture. J Sustain Agr 7:8187. https://doi.org/10.1300/J064v07n01_07

Hill SB, Vincent C, Chouinard G (1999) Evolving ecosystems approaches tofruit insect pest management. Agric Ecosyst Environ 73:107-110. https://doi.org/10.1016/S0167-8809(99)00019-5

Hokkanen HMT (2015) Integrated pest management at the crossroads: Science, politics, or business (as usual)? Arthropod-Plant Inte 9: 543-545. https://doi.org/10.1007/s11829-015-9403-y

Hollingsworth CS, Coli WM (2001) IPM adoption in the Northwestern US: An examination of the IPM continuum. Am J Alternative Agr 16:177-183. https://doi.org/10.2307/44509995

Hoppin JA, LePrevost CE (2017) Pesticides and human health. Pest management within the environment. In: Challenges for agronomists, ecologists, economists and policymakers. John Wiley \& Sons, Chichester, UK, pp. 251-273

Horgan FG (2017) Integrated pest management for sustainable rice cultivation: a holistic approach. In: Achieving Sustainable Cultivation of Rice, Burleigh Dodds, Cambridge, UK, pp. 271-292

Horlings LG, Marsden TK (2011) Towards the real green revolution? Exploring the conceptual dimensions of a new ecological modernisation of agriculture that could 'feed the world'. Global Environ Chang 21:441-452. https://doi.org/10.1016/j.gloenvcha.2011.01. 004

Hoy CW (2015) Agroecosystem health, agroecosystem resilience, and food security. J Environ Stud Sci 5:623-635. https://doi.org/10. $1007 /$ s13412-015-0322-0

Hoy CW (2020) Advances in understanding agroecosystems ecology and its applications in integrated pest management. In: Integrated management of insect pests. Current and future developments. Burleigh Dodds Science Publishing Limited, Cambridge, UK, pp. 131-160

Hoy CW, Bosserman S, MacDonald R (2016) Social networks, ecological frameworks, and local economies. In: Local Food Systems in Old Industrial Regions: Concepts, Spatial Contexte, and Local Practices. Routledge, pp. 51-76

Huan NH, Thiet LV, Chien HV, Heong KL (2005) Farmers' participatory evaluation of reducing pesticides, fertilizers and seed rates in rice farming in the Mekong Delta, Vietnam. Crop Prot 24:457-464. https://doi.org/10.1016/j.cropro.2004.09.013

Hufnagel J, Reckling M, Ewert F (2020) Diverse approaches to crop diversification in agricultural research. A review. Agron Sustain Dev 40:14. https://doi.org/10.1007/s13593-020-00617-4

Hurley TM, Sun H (2019) Softening shock and awe pest management in corn and soybean production with IPM principles. J Integr Pest Manage 10:1-8. https://doi.org/10.1093/jipm/pmz001 
Hutchins SH (1995) Free enterprise: the only sustainable solution to IPM implementation. J. Agric Entomol 12:211-217

Huxley J (1964) Essays of a Humanist (Education and Humanism p.132). Harmonds-worth, UK, Penguin

Iqbal M (2010) Concept and implementation of participation and empowerment: reflection from the coffee IPM-SECP. Hubs-Asia 10:1. https://doi.org/10.7454/mssh.v11/2.112

Isbell F, Adler PR, Eisenhauer N, Fornara D, Kimmel K, Kreme C, Letourneau DK, Liebma M, Polle HW, Quija S, Scherer-Lorenze M (2017) Benefits of increasing plant diversity in sustainable agroecosystems. J Ecol 105:871. https://doi.org/10.1111/13652745.12789

Jactel H, Verheggen F, Thiéry D, Escobar-Gutiérrez AJ, Gachet E, Desneux N (2019) Alternatives to neonicotinoids. Environ Int 129: 423-429. https://doi.org/10.1016/j.envint.2019.04.045

Jain HK (2010) The Green revolution: history, impact and future. Studium Press, Houston, TE

Jeger MJ (2000) Bottlenecks in IPM. Crop Prot 19:787-792

Jepson PC, Murray K, Bach O, Bonilla MA, Neumeister L (2020) Selection of pesticides to reduce human and environmental health risks: a global guideline and minimum pesticides list. Lancet Plan Health 4:e56-e63. https://doi.org/10.1016/S2542-5196(19)30266-9

Jørs E, Aramayo A, Huici O, Konradsen F, Gulis G (2017) Obstacles and opportunities for diffusion of integrated pest management strategies reported by Bolivian small-scale farmers and agronomists. Environ Health Insight 11:1178630217703390. https://doi.org/10.1177/ 1178630217703390

Juma C (2016) Innovation and its enemies: Why people resist new technologies. Oxford University Press

Kanter DR, Bartolini F, Kugelberg S, Leip A, Oenema O, Uwizeye A (2019) Nitrogen pollution policy beyond the farm. Nat Food 1:2732. https://doi.org/10.1038/s43016-019-0001-5

Karp DS, Chaplin-Kramer R, Meehan TD et al (2018) Crop pests and predators exhibit inconsistent responses to surrounding landscape composition. P Natl Acad Sci USA 115:E7863-E7870. https://doi. org/10.1073/pnas.1800042115

Kennedy GG, Sutton TB (2000) Emerging technologies for integrated pest management: Concepts, Research and Implementation. APS Press, St Paul, Minnesota

Kiritani K (2000) Integrated biodiversity management in paddy fields: shift of paradigm from IPM toward IBM. Integ Pest Manage Rev 5: 175-183. https://doi.org/10.1023/A:1011315214598

Kiritani K (2020) Understanding agroecosystems and pest management: from chemical control to integrated biodiversity management. In: Integrated management of insect pests. Current and future developments. Burleigh Dodds Science Publishing Limited, Cambridge, UK, pp. 97-130

Kogan M (1998) Integrated pest management: historical perspectives and contemporary developments. Annu Rev Entomol 43:243-270. https://doi.org/10.1146/annurev.ento.43.1.243

Kogan M, Heinrichs EA (2020) Integrated management of insect pests. Current and future developments. Burleigh Dodds Science Publishing Limited, Cambridge

Kogan M, Jepson P (2007) Perspectives in ecological theory and integrated pest management. Cambridge University Press, Cambridge, UK

Koul O, Cuperus GW (2007) Ecologically based integrated pest management: present concept and new solutions. In: Ecologically Based Pest Management, CABI, Oxfordshire, pp. 1-17

Koul O, Dhaliwal GS, Cuperus GW (2004) Integrated pest management: potential, constraints and challenges. CABI, Wallingford

Kronenberg J (2014) What can the current debate on ecosystem services learn from the past? Lessons from economic ornithology. Geoforum 55:164-177. https://doi.org/10.1016/j.geoforum.2014.06.011

Kuhn TS (1962) The structure of scientific revolutions. Second edition. University of Chicago Press
Kuyper TW, Struik PC (2014) Epilogue: global food security, rhetoric, and the sustainable intensification debate. Curr Opin Env Sustain 8: 71-79. https://doi.org/10.1016/j.cosust.2014.09.004

LaCanne CE, Lundgren JG (2018) Regenerative agriculture: merging farming and natural resource conservation profitably. PeerJ 6: e4428. https://doi.org/10.7717/peerj.4428

Lamarque P, Meyfroidt P, Nettier B, Lavorel S (2014) How ecosystem services knowledge and values influence farmers' decision-making. PloS One 9:e107572. https://doi.org/10.1371/journal.pone.0107572

Lamichhane JR, Barzman M, Booij K, Boonekamp P, Desneux N, Huber L, Kudsk P, Langrell SRH, Ratnadass A, Ricci P, Sarah J-L, Messéan A (2015) Robust cropping systems to tackle pests under climate change. A review. Agr Sustain Dev 35:443-459. https://doi. org/10.1007/s13593-014-0275-9

Lamichhane JR, Dachbrodt-Saayed S, Kudsk P, Messéan A (2016) Toward a reduced reliance on conventional pesticides in European agriculture. Plant Dis 100:10-24. https://doi.org/10.1094/PDIS-0515-0574-FE

Lamichhane JR, Messéan A, Ricci P (2019) Research and innovation priorities as defined by the Ecophyto plan to address current crop protection transformation challenges in France. Adv Agron 154:81152. https://doi.org/10.1016/bs.agron.2018.11.003

Lamichhane JR, Arseniuk E, Boonekamp P, Czembor J, Decroocq V, Enjalbert J, Finckh MR, Korbin M, Koppel M, Kudsk P, Mesterhazy A, Sosnowska D, Zimnoch-Guzowska E, Messéan A (2018) Advocating a need for suitable breeding approaches to boost integrated pest management: a European perspective. Pest Manage Sci 74:1219-1227. https://doi.org/10.1002/ps.4818

Lamichhane JR, Dürr C, Schwank AA, Robin MH, Sarthou JP, Cellier V, Messéan A, Aubertot J-N (2017) Integrated management of damping-off diseases. A review. Agron Sustain Dev 37:10. https:// doi.org/10.1007/s13593-017-0417-y

Landis DA (2017) Designing agricultural landscapes for biodiversitybased ecosystem services. Basic Appl Ecol 18:1-12. https://doi. org/10.1016/j.baae.2016.07.005

Landis DA, Wratten SD, Gurr GM (2000) Habitat management to conserve natural enemies of arthropod pests in agriculture. Annu Rev Entomol 45:175-201. https://doi.org/10.1146/annurev.ento.45.1. 175

Leake A (2000) The development of integrated crop management in agricultural crops: comparisons with conventional methods. Pest Manag Sci 56:950-953. https://doi.org/10.1002/15264998(200011)56:11\%3C950::AID-PS234\%3E3.0.CO;2-5

Lechenet M, Dessaint F, Py G, Makowski D, Munier-Jolain N (2017a) Reducing pesticide use while preserving crop productivity and profitability on arable farms. Nat Plants 3:1-6. https://doi.org/10.1038/ nplants. 2017.8

Lechenet M, Deytieux V, Antichi D, Aubertot J-N et al (2017b) Diversity of methodologies to experiment Integrated PestManagement in arable cropping systems: Analysis and reflections based on a European network. Eur J Agron 83:86-99. https://doi.org/10.1016/j.eja.2016. 09.012

Lefebvre M, Langrell SRH, Gomez-Y-Paloma S (2015) Incentives and policies for integrated pest management in Europe: a review. Agron Sustain Dev 35:27-45. https://doi.org/10.1007/s13593-014-0237-2

Lescourret F (2017) Toward a reduced use of pesticides in European farming systems: An introduction to the PURE project. Crop Prot 97:7-9. https://doi.org/10.1016/j.cropro.2016.12.004

Lescourret F, Dutoit T, Rey F, Côte F, Hamelin M, Lichtfouse E (2015a) Agroecological engineering. Agron Sustain Dev 35:1191-1198. https://doi.org/10.1007/s13593-015-0335-9

Lescourret F, Poncet C, Simon S (2016) Insights into the ecological control of pests in horticulture. Acta Hortic 1137:91-104. https:// doi.org/10.17660/ActaHortic.2016.1137.14

Lescourret F, Magda D, Richard G et al (2015b) A social-ecological approach to managing multiple agro-ecosystem services. Curr 
Opin Environ Sustain 14:68-75. https://doi.org/10.1016/j.cosust. 2015.04.001

Lemos F, Sarmento RA, Teodoro AV, dos Santos GR, do Nascimento IR (2011) Agroecological strategies for arthropod pest management in Brazil. Recent Pat Food Nut Agr 3:142-154

Letourneau DK, Fitzsimmons MI, Nieto DJ (2017) Approaches in Plant Protection: Science, Technology, Environment and Society. In: Environmental pest management: challenges for agronomists, ecologists, economists and policymakers. John Wiley \& Sons, Chichester, UK, pp. 21-53

Lewis WJ, van Lenteren JC, Phatak SC, Tumlinson JH (1997) A total system approach to sustainable pest management. P Natl Acad Sci 94:12243-12248. https://doi.org/10.1073/pnas.94.23.12243

Li W, Wang L, Jaworski CC, Yang F, Liu B, Jiang Y, Lu Y, Wu K, Desneux N (2020) The outbreaks of nontarget mirid bugs promote arthropod pest suppression in Bt cotton agroecosystems. Plant Biotechnol J 18:322-324. https://doi.org/10.1111/pbi.13233

Lichtenberg EM, Kennedy CM, Kremen C et al (2017) A global synthesis of the effects of diversified farming systems on arthropod diversity within fields and across agricultural landscapes. Glob Change Biol 23:4946-4957. https://doi.org/10.1111/gcb.13714

Litsinger JA, Libetario EM, Canapi BL (2009) Eliciting Farmer Knowledge, Attitudes, and Practices in the Development of Integrated Pest Management Programs for Rice in Asia. In: Integrated Pest Management: Dissemination and Impact. Springer, Dordrecht, pp. 119-273. https://doi.org/10.1007/978-1-4020-89909_5

Loorbach D, Frantzeskaki N, Avelino F (2017) Sustainability transitions research: transforming science and practice for societal change. Annu Rev Environ Resour 42:599-626. https://doi.org/10.1146/ annurev-environ-102014-021340

Lu Y, Wu K, Jiang Y, Guo Y, Desneux N (2012) Widespread adoption of Bt cotton and insecticide decrease promotes biocontrol services. Nature 487:362-365. https://doi.org/10.1038/nature11153

Lu Y, Wu K, Jiang Y, Xia B, Li P, Feng H, Wyckhuys KA, Guo Y (2010) Mirid bug outbreaks in multiple crops correlated with wide-scale adoption of Bt cotton in China. Science 328:1151-1154. https:// doi.org/10.1126/science.1187881

Lucas P (2007) Le concept de la protection intégrée des cultures. Innov Agron 1:15-21

Lucas P, Ratnadass A, Deguine J-P (2017) Moving from Integrated Pest Management to Agroecological Crop Protection. In: Agroecological Crop Protection. Springer Science+Business Media B.V, Dordrecht, pp 24-33

Lundgren JG, Fausti SW (2015) Trading biodiversity for pest problems. Sci Adv 1:e1500558. https://doi.org/10.1126/sciadv.1500558

Magarey RD, Klammer SS, Chappell TM, Trexler CM, Pallipparambil GR, Hain EF (2019) Eco-efficiency as a strategy for optimizing the sustainability of pest management. Pest Manage Sci 75:3129-3134. https://doi.org/10.1002/ps.5560

Malézieux E (2017) Agroecology, a 21st Century Agricultural Revolution? In: Agroecological Crop Protection. Springer Science+Business Media B.V., Dordrecht, pp. 2-6

Malézieux E, Crozat Y, Dupraz C, Laurans M, Makowski D, OzierLafontaine H, Rapidel B, de Tourdonnet S, Valantin-Morison M (2009) Mixing plant species in cropping systems: concepts, tools and models. A review. Agron Sustain Dev 29:43-62. https://doi. org/10.1007/978-90-481-2666-8_22

Maredia KM, Dakouo D, Mota-Sanchez D (2003) Integrated pest management in the global arena. CABI, Wallingford

Marrone PG (2009) Barriers to adoption of biological control agents and biological pesticides. In: Integrated Pest Management. Cambridge University Press, Cambridge, UK, pp. 163-178

Matyjaszczyk E (2019) Problems of implementing compulsory integrated pest management. Pest Manage Sci 75:2063-2067. https://doi.org/ $10.1002 /$ ps.5357
Meehan TD, Gratton C (2016) A Landscape View of Agricultural Insecticide Use across the Conterminous US from 1997 through 2012. PloS One 1:e0166724. https://doi.org/10.1371/journal.pone. 0166724

Meynard JM, Dedieu B, Bos AB (2012) Re-design and co-design of farming systems. An overview of methods and practices. In: Farming Systems Research into the 21st century: The new dynamic. Springer, Dordrecht, pp. 405-429

Möhring N, Wuepper D, Musa T, Finger R (2020) Why farmers deviate from recommended pesticide timing: the role of uncertainty and information. Pest Manag Sci 76:2787-2798. https://doi.org/10. $1002 /$ ps. 5826

Morales H, Perfecto I (2000) Traditional knowledge and pest management in the Guatemalan highlands. Agric Hum Values 17:49-63. https://doi.org/10.1023/A:1007680726231

Morse S (2009) IPM, ideals and realities in developing countries. In: Integrated Pest Management, Concepts, Tactics, Strategies and Case Studies. Cambridge University Press, Cambridge, pp. 458-470

Morse S, Buhler W (1997) IPM in developing countries: the danger of an ideal. Integr Pest Manag Rev 2:175-185. https://doi.org/10.1023/A: 1018457219228

Mourtzinis S, Krupke CH, Esker PD, Varenhorst A, Arneson NJ, Bradley CA, Byrne AM, Chilvers MI, Giesler LJ, Herbert A, Kandel YR (2019) Neonicotinoid seed treatments of soybean provide negligible benefits to US farmers. Sci Rep 9:11207. https://doi.org/10.1038/ s41598-019-47442-8

Muneret L, Mitchell M, Seufert V, Aviron S, Pétillon J, Plantegenest M, Thiéry D, Rusch A (2018) Evidence that organic farming promotes pest control. Nat Sustain 1:361-368. https://doi.org/10.1038/ s41893-018-0102-4

Munyua C (2003) Challenges in implementing integrated pest management (IPM) practices: Implications for agricultural extension. Proceedings of the 19th Annual Conference of the Association for Agricultural and Extension Education, Raleigh, North Carolina, USA. pp. 469-479

Murray DL, Taylor PL (2000) Claim no easy victories: evaluating the pesticide industry's global safe use campaign. World Dev 28:17351749. https://doi.org/10.1016/S0305-750X(00)00059-0

Murray K, Jepson P, Bouska C et al. (2021) Integrated Pest Management Summit Reveals Barriers, Needs, and Goals for Agricultural Extension. J Extension 58(3). Retrieved from https://tigerprints. clemson.edu/joe/vol58/iss $3 / 24$

Nampeera EL, Nonnecke GR, Blodgett SL, Tusiime SM, Masinde DM, Wesonga JM, Murungi LK, Baidu-Forson J, Abukutsa-Onyango MO (2019) Farmers' Knowledge and Practices in the Management of Insect Pests of Leafy Amaranth in Kenya. J Integr Pest Manag 10: 31. https://doi.org/10.1093/jipm/pmz029

Naranjo SE (2001) Conservation and evaluation of natural enemies in IPM systems for Bemisia tabaci. Crop Prot 20:835-885. https:// doi.org/10.1016/S0261-2194(01)00115-6

Naranjo SE, Ellsworth PC (2009) Fifty years of the integrated control concept: moving the model and implementation forward in Arizona. Pest Manag Sci 65:1267-1286. https://doi.org/10.1002/ ps. 1861

Naranjo SE, Ellsworth PC, Frisvold GB (2015) Economic value of biological control in integrated pest management of managed plant systems. Annu Rev Entomol 60:621-645. https://doi.org/10.1146/ annurev-ento-010814-021005

Ngin C, Suon S, Tanaka T, Yamauchi A, Kawakita K, Chiba S (2017) Impact of insecticide applications on arthropod predators and plant feeders in Cambodian rice fields. Phytobiomes 1:128-137. https:// doi.org/10.1094/PBIOMES-01-17-0002-R

Nicholls CI, Altieri MA (2004) Agroecological bases of ecological engineering for pest management. In: Ecological engineering for pest management: advances in habitat manipulation for arthropods. CSIRO, Collingwood, pp. 33-54 
Nilda PC, Vázquez L (2004) Manejo ecológico de plagas. La Habana, Cuba. Editorial Centro de Estudios de Desarrollo Agrario y Rural, pp. $127-284$

Norris RF, Caswell-Chen EP, Kogan M (2003) Concepts in integrated pest management. Prentice Hall, Upper Saddle River, NJ

Norton G, Mullen J (1994) Economic evaluation of integrated pest management programs: a literature review. Virginia Polytech Inst State Univ, Blacksburg

Norton G, Alwang J, Kassie M, Muniappan R (2019) Economic Impacts of Integrated Pest Management Practices in Developing Countries. In: The Economics of Integrated Pest Management of Insects. CABI Publishing, Boston, MA, pp. 140-154

Ohmart C (2008) IPM implementation at field level: "What are the impediments to grower adoption of IPM? Why do they exist and what can be done to get around them? ". In: ENDURE International Conference 2008, pp. 1-10

Ohmart CP (2009) IPM implementation - overcoming barriers to grower adoption. Pesticides News 85:20-22

Onillon JC, Gullino LM (1999) Implementation of IPM: from research to the consumer. In: Integrated Pest and Disease Management in Greenhouse Crops. Developments in Plant Pathology. Springer, Dordrecht, pp. 411-419. https://doi.org/10.1007/0-306-47585-5_29

Onstad DW, Crain PR (2019) Major economic issues in integrated pest management. In: The economics of integrated pest management of insects. CABI, Wallingford, pp. 1-13

Orr A (2003) Integrated pest management for resource-poor African farmers: Is the emperor naked? World Dev 31:831-845. https:// doi.org/10.1016/S0305-750X(03)00015-9

Palis FG (2006) The role of culture in farmer learning and technology adoption: A case study of farmer field schools among rice farmers in central Luzon, Philippines. Agric Hum Values 23:491-500. https:// doi.org/10.1007/s10460-006-9012-6

Palti J (1981) Cultural Practices and Infectious Crop Diseases. SpringerVerlag

Paredes D, Karp DS, Chaplin-Kramer R, Benítez E, Campos M (2019) Natural habitat increases natural pest control in olive groves: economic implications. J Pest Sci 92:1111-1121. https://doi.org/10. 1007/s10340-019-01104-w

Parsa S, Morse S, Bonifacio A, Chancellor TCB, Condori B, CrespoPérez V, Hobbs SLA, Kroschel J, Ba ML, Rebaudo F, Sherwood SG, Vanek SJ, Faye E, Herrera MA, Dangles O (2014) Obstacles to integrated pest management adoption in developing countries. PNAS 111:3889-3894. https://doi.org/10.1073/pnas.1312693111

Pedigo LP (1989) Entomology and pest management. Macmillan Publishing Company

Pedigo LP (1995) Closing the gap between IPM theory and practice. J Agric Entomol 12:171-181

Penvern S, Fernique S, Cardona A, Herz A, Ahrenfeldt E, Dufils A, Jamar A, Korsgaard M, Kruczyńska D, Matray S, Ozolina-Pole L, Porcel M, Ralle B, Steinemann B, Świergiel W, Tasin M, Telfser J, Warlop F, Sigsgaard L (2019) Farmers' management of functional biodiversity goes beyond pest management in organic European apple orchards. Agric Ecosyst Environ 284:106555. https://doi. org/10.1016/j.agee.2019.05.014

Perrin RM (1997) Crop protection: taking stock for the new millennium. Crop Prot 16:449-456. https://doi.org/10.1016/S0261-2194(97) 00014-8

Peshin R, Dhawan AK (2009) Integrated Pest Management: Volume 1: Innovation-Development Process. Springer, Science \& Business Media

Peshin R, Zhang W (2014) Integrated pest management and pesticide use. In: Integrated Pest Management. Springer, Dordrecht, pp. 1-46. https://doi.org/10.1007/978-94-007-7796-5_1

Peterson RK, Higley LG, Pedigo LP (2018) Whatever happened to IPM? Am Entomol 64:146-150. https://doi.org/10.1093/ae/tmy049
Pimentel D (1982) Perspectives of integrated pest management. Crop Prot 1:5-26. https://doi.org/10.1016/0261-2194(82)90054-0

Pimentel D, Peshin R (2014) Integrated pest management: pesticide problems. Springer Science \& Business Media

Piwowar A (2021) The use of pesticides in Polish agriculture after integrated pest management (IPM) implementation. Environ Sci Pollut Res 2021:1-15. https://doi.org/10.1007/s11356-020-12283-w

Petit S, Lescourret S (2019) La biodiversité au cœur des agroécosystèmes : où en sommes-nous aujourd'hui ? Innov Agron 75:15-27

Power AG (2010) Ecosystem services and agriculture: tradeoffs and synergies. Philos T Roy Soc B 365:2959-2971. https://doi.org/10.1098/ rstb. 2010.0143

Pretty J (2005) Sustainability in agriculture: recent progress and emergent challenges. Sustainability in agriculture. Iss Environ Sci Technol 21: $1-15$

Pretty J, Benton TG, Bharucha ZP, Dicks LV, Flora CB, Godfray HCJ, Goulson D, Hartley S, Lampkin N, Morris C, Pierzynski G (2018) Global assessment of agricultural system redesign for sustainable intensification. Nat Sustain 1:441-446. https://doi.org/10.1038/ s41893-018-0114-0

Pretty J, Bharucha ZP (2015) Integrated pest management for sustainable intensification of agriculture in Asia and Africa. Insects 6:152-182. https://doi.org/10.3390/insects6010152

Pretty J, Toulmin C, Williams S (2011) Sustainable intensification in African agriculture. Int J Agr Sustain 9:5-24. https://doi.org/10. 3763/ijas.2010.0583

Prokopy RJ (1994) Integration in orchard pest and habitat management: a review. Agric Ecosyst Environ 50:1-10. https://doi.org/10.1016/ 0167-8809(94)90120-1

Prokopy R, Kogan M (2003) Integrated pest management. In: Encyclopedia of Insects. Academic Press, San Diego, pp. 589-595

Puente M, Darnall N, Forkner RE (2011) Assessing integrated pest management adoption: Measurement problems and policy implications. Environ Manage 48:1013-1023. https://doi.org/10.1007/s00267011-9737-X

Purvis B, Mao Y, Robinson D (2019) Three pillars of sustainability: in search of conceptual origins. Sustain Sci 14:681-695. https://doi. org/10.1007/s11625-018-0627-5

Radcliffe EB, Hutchison WD, Cancelado RE (2009) Integrated pest management: concepts, tactics, strategies and case studies. Cambridge University Press

Rajotte EG, Norton GW, Luther GC, Barrera V, Heong KL (2005) IPM transfer and adoption. In: Globalizing Integrated Pest Management: A Participatory Research Process. Cambridge University Press, pp. $143-157$

Randriamanantsoa R, Ratnadass A (2017) Agroecological Management of Insect Pests of Upland Rice in Madagascar. In: Agroecological Crop Protection. Springer Science+Business Media B.V., Dordrecht, pp. 141-145

Rapisarda C, Cocuzza GEM (2018) Integrated Pest Management in Tropical Regions. CABI, Wallingford, UK

Ratnadass A (2017) Feedback and common approaches to agroecological crop protection : further examples.. In: Agroecological Crop Protection. Springer Science+Business Media B.V., Dordrecht, pp. 110-159

Ratnadass A (2020) Crop Protection for Agricultural Intensification Systems in Sub-Saharan Africa. Sustain Agric Rev 39:1-34. https://doi.org/10.1007/978-3-030-38881-2_1

Ratnadass A, Barzman M (2014) Ecological Intensification for Crop Protection. Sustain Agric Rev 14:53-81. https://oi.org/10.1007/ 978-3-319-06016-3 3

Ratnadass A, Fernandes P, Avelino J, Habib R (2012) Plant species diversity for sustainable management of crop pests and diseases in agroecosystems: a review. Agron Sustain Dev 32:273-303. https:// doi.org/10.1007/s13593-011-0022-4 
Rebaudo F, Carpio C, Crespo-Pérez V, Herrera M, de Scurrah MM, Canto RC, Montañez AG, Bonifacio A, Mamani M, Saravia R, Dangles O (2014) Agent-based models and integrated pest management diffusion in small scale farmer communities. In: Integrated Pest Management. Springer, Dordrecht, pp. 367-383. https://doi. org/10.1007/978-94-007-7802-3_15

Rebaudo F, Dangles O (2011) Coupled Information Diffusion-Pest Dynamics Models Predict Delayed Benefits of Farmer Cooperation in Pest Management Programs. PLoS Comput Biol 7: e1002222. https://doi.org/10.1371/journal.pcbi.1002222

Rebaudo F, Dangles O (2013) An agent-based modeling framework for integrated pest management dissemination programs. Environ Modell Softw 45:141-149. https://doi.org/10.1016/j.envsoft.2012. 06.014

Reddy PP (2017) Agro-ecological Approaches to Pest Management for Sustainable Agriculture. Springer Science Nature Singapore Pte Ltd

Redlich S, Martin EA, Steffan-Dewenter I (2018) Landscape-level crop diversity benefits biological pest control. J Appl Ecol 55:24192428. https://doi.org/10.1111/1365-2664.13126

Reid W, Mooney H, Cropper A et al (2005) Ecosystems and human wellbeing: synthesis. Millenium ecosystem assessment. Island Press, Washington DC

Rejesus RM, Jones MS (2020) Perspective: enhancing economic evaluations and impacts of integrated pest management farmer field schools (IPM-FFS) in low-income countries. Pest Manag Sci 2020:1-10. https://doi.org/10.1002/ps.5912

Rejesus RM, Palis FG, Lapitan AV, Chi TTN, Hossain M (2009) The impact of integrated pest management information dissemination methods on insecticide use and efficiency: evidence from rice producers in South Vietnam. Rev Agric Econ 31:814-833. https://doi. org/10.1111/j.1467-9353.2009.01468.x

Reteau A (2017) The Development of Crop Protection: A Critical Look through the Eyes of a Science Historian. In: Agroecological Crop Protection. Springer Science+Business Media B.V., Dordrecht, pp. 19-24

Ricci P, Bui S, Lamine C (2011) Repenser la protection des cultures: innovations et transitions. Editions Quae, Versailles

Ricci P, Messean A (2015) Stratégies intégratives et innovations systémiques: sortir du cadre. Innov Agron 46:147-155

Robinson C, Portier CJ, Čavoški A, Mesnage R, Roger A, Clausing P, Whaley P, Muilerman H, Lyssimachou A (2020) Achieving a High Level of Protection from Pesticides in Europe: Problems with the Current Risk Assessment Procedure and Solutions. Eur J Risk Regul 11:450-480. https://doi.org/10.1017/err.2020.18

Rodenburg J, Schut M, Demont M, Klerkx L, Gbèhounou G, Oude Lansink A, Mourits M, Rotteveel T, Kayeke J, van Ast A, Akanvou L (2015) Systems approaches to innovation in pest management: reflections and lessons learned from an integrated research program on parasitic weeds in rice. Int J Pest Manage 61:329-339. https://doi.org/10.1080/09670874.2015.1066042

Rola AC, Pingali PL (1993) Pesticides, rice productivity, and farmers' health: an economic assessment. IRRI, Manila

Romeis J, Naranjo SE, Meissle M, Shelto AM (2019) Genetically engineered crops help support conservation biological control. Biol Control 130:136-154. https://doi.org/10.1016/j.biocontrol. 2018.10.001

Rosenheim JA, Cass BN, Kahl H, Steinmann KP (2020) Variation in pesticide use across crops in California agriculture: Economic and ecological drivers. Sci Total Environ 733:138683. https://doi.org/ 10.1016/j.scitotenv.2020.138683

Rosenheim JA, Coll M (2008) Pest-centric versus process-centric research approaches in agricultural entomology. Am Entomol 54: 70-72 https://rosenheim.faculty.ucdavis.edu/wp-content/uploads/ sites/137/2014/09/Rosenheim-Coll.-2008.-Am.-Entomol..pdf
Ruesink WG (1980) Economics of integrated pest management: discussion - an entomologists views of IPM research needs. Am J Agr Econ 62:1014-1015. https://doi.org/10.2307/1240304

Rutherford RS, Conlong DE (2010) Combating sugarcane pests in South Africa: from researching biotic interactions to bio-intensive integrated pest management in the field. Proc Int Soc Sugar Cane Technol 27:1-17

Samiee A, Rezvanfar A, Faham E (2009) Factors influencing the adoption of integrated pest management (IPM) by wheat growers in Varamin County, Iran. Afr J Agr Res 4:491-497. https://doi.org/ 10.5897/AJAR.9000337

Sánchez-Bayo F, Wyckhuys KAG (2019) Worldwide decline of the entomofauna: A review of its drivers. Biol Conserv 232:8-27. https:// doi.org/10.1016/j.biocon.2019.01.020

Schäffer A, Filser J, Frische T, Gessner M, Köck W, Kratz W, Liess M, Nuppenau E-A, Roß-Nickoll M, Schäfer R, Scheringer M (2018) The Silent Spring - On the need for sustainable plant protection. Leopoldina Discussions 16, Halle

Schut M, Rodenburg J, Klerkx L, van Ast A, Bastiaans L (2014) Systems approaches to innovation in crop protection. A systematic literature review. Crop Prot 56:98-108. https://doi.org/10.1016/j.cropro.2013. 11.017

Sébillotte M (2006) Penser et agir en agronome. In : L'Agronomie aujourd'hui. Quæ, Versailles, pp. 1-29

Sheahan M, Barrett CB, Goldvale C (2017) Human health and pesticide use in Sub-Saharan Africa. Agric Econ 48:27-41. https://doi.org/10. 1111/agec. 12384

Shennan C, Cecchettini CL, Goldman GB, Zalom FG (2001) Profiles of California farmers by degree of IPM use as indicated by selfdescriptions in a phone survey. Agric Ecosyst Environ 84:267275. https://doi.org/10.1016/S0167-8809(00)00248-6

Sherman J, Gent DH (2014) Concepts of sustainability, motivations for pest management approaches, and implications for communicating change. Plant Dis 98:1024-1035. https://doi.org/10.1094/PDIS-0314-0313-FE

Simon S, Lesueur-Jannoyer M, Plénet D, Lauri P-É, Le Bellec F (2017a) Methodology to design agroecological orchards: Learnings from onstation and on-farm experiences. Eur J Agron 82:320-330. https:// doi.org/10.1016/j.eja.2016.09.004

Simon S, Marliac G, Capowiez Y (2017b) Gestion de la strate herbacée pour favoriser la régulation des ravageurs en vergers de pommiers en France. In: Agroecological Crop Protection. Springer Science+ Business Media B.V., Dordrecht, pp. 141-145

Simon S, Marliac G, Capowiez Y (2017c) Managing Plant Ground Cover to Control Pests in Apple Orchards in France. In: Agroecological Crop Protection. Springer Science+Business Media B.V., Dordrecht, pp. 125-128

Simon S, Rusch A, Wyss E, Sarthou J-P (2014) Conservation Biocontrol: Principles and Implementation in Organic Farming. In: Organic Farming, Prototype for Sustainable Agricultures. Springer Science+Business Media Dordrecht, pp. 83-105

Sinclair F, Coe R (2019) The options by context approach: a paradigm shift in Agronomy. Exp Agr 55:1-13. https://doi.org/10.1017/ S0014479719000139

Sinzogan A, Vayssières J-F, Ratnadass A (2017) Agroecological Management of Mango Fruit Flies in Benin. In: Agroecological Crop Protection. Springer Science+Business Media B.V., Dordrecht, pp. 129-135

Sivapragasam A (2004) Brassica IPM adoption: progress and constraints in south-east Asia. In: The Management of Diamondback Moth and Other Crucifer Pests. Proc Third Int Workshop 29. Melbourne, Australia, pp. 11-18

Smith E (1983) Integrated pest management (IPM) - specific needs of developing countries. Int J Trop Insect Sci 4:173-177. https://doi. org/10.1017/S1742758400004197 
Smith RF, Reynolds HT (1966) Principles, Definitions and Scope of Integrated Pest Management. Proc FAO Symp IntegrbPest Contr $1: 11-17$

Smith RF, Smith GL (1949) Supervised control of insects. Calif Agr 3:312

Smith P, van den Bosch R (1967) What is integrated pest management? In: Pest control. Academic Press, New-York, pp. 295-340

Spangenberg JH, Douguet JM, Settele J, Heong KL (2015) Escaping the lock-in of continuous insecticide spraying in rice: Developing an integrated ecological and socio-political DPSIR analysis. Ecol Model 295:188-195. https://doi.org/10.1016/j.ecolmodel.2014.05. 010

Spurgeon DW (2007) Ecologically Based Integrated Pest Managementin Cotton. In: Ecologically Based Integrated Pest Management. CABI, Wallingford, pp. 367-405

Stenberg JA (2017) A Conceptual Framework for Integrated Pest Management. Trends in Plant Sci 22:759-769. https://doi.org/10. 1016/j.tplants.2017.06.010

Stern VM, Smith RF, van den Bosch R, Hagen KS (1959) The integrated control concept. Hilgardia 29:81-101

Stetkiewicz S, Bruce A, Burnett FJ, Ennos RA, Topp CF (2018) Perception vs practice: Farmer attitudes towards and uptake of IPM in Scottish spring barley. Crop Prot 112:96-102. https://doi. org/10.1016/j.cropro.2018.05.005

Struelens Q, Silvie P (2020) Orienting insecticide research in the tropics to meet the sustainable development goals. Curr Opin Insect Sci 40: 24-30. https://doi.org/10.1016/j.cois.2020.05.015

Struik PC, Kuyper TW (2017) Sustainable intensification in agriculture: the richer shade of green. A review. Agron Sustain Dev 37:39. https://doi.org/10.1007/s13593-017-0445-7

Suckling DM, Stringer LD, Stephens AE, Woods B, Williams DG, Baker G, El-Sayed AM (2014) From integrated pest management to integrated pest eradication: technologies and future needs. Pest Manage Sci 70:179-189. https://doi.org/10.1002/ps.3670

Suckling DM, Tobin PC, McCullough DG, Herms DA (2012) Combining tactics to exploit Allee effects for eradication of alien insect populations. J Econ Entomol 105:1-13. https://doi.org/10. 1603/EC11293

Tabashnik B, Sisterson M, Ellsworth P, Dennehy TJ, Antilla L, Liesner L, Whitlow M, Staten RT, Fabrick JA, Unnithan GC, Yelich AJ, Ellers-Kirk C, Harpold VS, Li X, Carrière Y (2010) Suppressing resistance to Bt cotton with sterile insect releases. Nat Biotechnol 28:1304-1307. https://doi.org/10.1038/nbt.1704

Teng PS, Savary S (1992) Implementing the systems approach in pest management. Agr Syst 40:237-264. https://doi.org/10.1016/0308521X(92) $90023-\mathrm{H}$

Teoh CH, Ooi ACP (1986) Towards more effective plant protection in the tropics. J Plant Prot Trop (Malaysia) 3:51-72

Thérond O, Duru M, Martin G, Martin-Clouaire R, Magne MA, Justes E, Journet EP, Aubertot J-N, Savary S, Bergez JE, Sarthou J-P (2015) How to implement biodiversity-based agriculture. In: Agroecological Engineering. Springer, Heidelberg, pp.1259-1281

Thiel L, Mergenthaler M, Haberlah-Korr V (2021) Wahrgenommene Umsetzung des integrierten Pflanzenschutzes bei landwirtschaftlichen Betrieben in Nordwestdeutschland. Gesunde Pflanzen. https://doi.org/10.1007/s10343-021-00548-4

Thomas MB (1999) Ecological approaches and the development of "truly integrated" pest management. P Natl Acad Sci 96:5944-5951

Thorburn C (2014) Empire strikes back: the making and unmaking of Indonesia's national integrated pest management program. Agroecol Sustain Food 38:3-24. https://doi.org/10.1080/21683565.2013. 825828

Thorburn C (2015) The rise and demise of integrated pest management in rice in Indonesia. Insects 6:381-408

Tilman D, Reich PB, Isbell F (2012) Biodiversity impacts ecosystem productivity as much as resources, disturbance, or herbivory. $\mathrm{P}$
Natl Acad Sci 109:10394-10397. https://doi.org/10.1073/pnas. 1208240109

Tilman D, Reich PB, Knops JMH (2006) Biodiversity and ecosystem stability in a decade-long grassland experiment. Nature 441:629 632. https://doi.org/10.1038/nature04742

Tittonell P (2014) Ecological intensification of agriculture - sustainable by nature. Curr Opin Environ Sustain 8:53-61. https://doi.org/10. 1016/j.cosust.2014.08.006

Toleubayev K, Jansen K, van Huis A (2011) From Integrated Pest Management to Indiscriminate Pesticide Use in Kazakhstan. J Sustain Agr 35:350-375. https://doi.org/10.1080/10440046.2011. 562036

Tripp R, Wijeratne M, Piyadasa VH (2005) What should we expect from farmer field schools? A Sri Lanka case study. World Dev 33:17051720. https://doi.org/10.1016/j.worlddev.2005.04.012

Trumble JT (1998) IPM: Overcoming Conflicts in Adoption. Integr Pest Manage Rev 3:195-207. https://doi.org/10.1023/A:1009691223903

UN (United Nations) (2017) Report of the Special Rapporteur on the right to food. Human Rights Council, Thirty-fourth session, 27 February24 March 2017, Geneva, Switzerland. Accessed 12 April 2020. https://documents-dds-ny.un.org/doc/UNDOC/GEN/G17/017/85/ PDF/G1701785.pdf?OpenElement

Uneke CJ (2007) Integrated pest management for developing countries: a systemic overview. In: Nova Science Publishers, New York, pp. 127-203

Untung K (1995) Institutional constraints on IPM implementation in Indonesia. In: Institutional Constraints to IPM. 13 Int Plant Prot Congr, The Hague July 2-7 1995, pp. 35-47

van de Fliert E (1993) Integrated pest management: farmer field schools generate sustainable practices: a case study in Central Java evaluating IPM training. Wageningen University, Netherlands

van den Berg H (2004) IPM Farmer Field Schools: A synthesis of 25 impact evaluations by Wageningen University, January 2004. Prepared for the Global IPM Facility

van den Berg H, Jiggins J (2007) Investing in farmers - the impacts of farmer field schools in relation to integrated pest management. World Dev 35:663-686

van den Bosch R (1965) Practical application of the integrated control concept in California. Proc Int Congr Entomol 12 London, pp. 59597

van den Bosch R (1989) The pesticide conspiracy. Univ of California Press

van den Bosch R, Stern VM (1962) The integration of chemical and biological control of arthropod pests. Annu Rev Entomol 7:367386. https://doi.org/10.1146/annurev.en.07.010162.002055

van Huis A, Meerman F (1997) Can we make IPM work for resourcepoor farmers in Sub-Saharan Africa? Int J Pest Manage 43:313-320. https://doi.org/10.1080/096708797228636

van Lenteren JC (1998) Sustainable and safe crop protection: a reality? Mededelingen - Universiteit Gent, Faculteit Landbouwkundige en Toegepaste Biologische Wetenschappen 63:409-414

van Lenteren JC (2012) The state of commercial augmentative biological control: plenty of natural enemies, but a frustrating lack of uptake. BioControl 57:1-20. https://doi.org/10.1007/s10526-011-9395-1

Vanloqueren G, Baret PV (2009) How agricultural research systems shape a technological regime that develops genetic engineering but locks out agroecological innovations. Res Policy 38:971-983. https://doi.org/10.1016/j.respol.2009.02.008

van Mele P (2008) The importance of ecological and socio-technological literacy in R\&D priority setting: the case of a fruit innovation system in Guinea, West Africa. Int J Agric Sustain 6:183-194. https://doi. org/10.3763/ijas.2008.0369

van Mele P, Ahmad S, Magor NP (2005) Innovations in rural extension: case studies from Bangladesh. CABI, Wallingford

van Schoubroeck F (1999) Learning to fight a fly: developing citrus IPM in Bhutan. Wageningen University, Netherlands 
van Wilgen BW, Moran VC, Hoffmann JH (2013) Some Perspectives on the Risks and Benefits of Biological Control of Invasive Alien Plants in the Management of Natural Ecosystems. Environ Manage 52:531-540. https://doi.org/10.1007/s00267013-0099-4

Vargas RI, Mau RFL, Jang EB, Faust RM, Wong L (2008) The Hawaii fruit fly area-wide pest management program. In: Areawide IPM: theory to implementation. CAB International, Wallingford, pp 300 332

Vasileiadis V (2017) Economic sustainability: Less pesticide rarely causes loss. Nature Plants 3:17016. https://doi.org/10.1038/nplants. 2017.16

Vasileiadis VP, Dachbrodt-Saaydeh S, Kudsk P et al (2017) Sustainability of European winter wheat- and maize-based cropping systems: Economic, environmental and social ex-post assessment of conventional and IPM-based systems. Crop Prot 97:60-69. https:// doi.org/10.1016/j.cropro.2016.11.002

Vayssières J, Vigne M, Alary V, Lecomte $P$ (2011) Integrated participatory modelling of actual farms to support policy making on sustainable intensification. Agr Syst 104:146-161. https://doi.org/10.1016/ j.agsy.2010.05.008

Vega D, Gazzano Santos MI, Salas-Zapata W, Poggio SL (2020) Revising the concept of crop health from an agroecological perspective. Agroecol Sustain Food 44:215-237. https://doi.org/10.1080/ 21683565.2019.1643436

Veres A, Wyckhuys KAG, Kiss J, Tóth F, Burgio G, Pons X, Avilla C, Vidal S, Razinger J, Bazok R, Matyjaszczyk E, Milosavljević I, Vi Le X, Zhou W, Zhu Z-R, Tarno H, Hadi B, Lundgren J, Bonmatin JM, van Lexmond MB, Aebi A, Rauff A, Furlan L (2020) An update of the Worldwide Integrated Assessment (WIA) on systemic pesticides. Part 4: Alternatives in major cropping systems. Environ Sci Pollut Res 27:29867-29899. https://doi.org/10.1007/s11356-02009279-x

Vialatte A, Barnaud C, Blanco J, Ouin A, Choisis J-P, Andrieu E, Sheeren D, Ladet S, Deconchat M, Clément F, Esquerré D, Sirami C (2019) A conceptual framework for the governance of multiple ecosystem services in agricultural landscapes. Landscape Ecol 4: 1653-1673. https://doi.org/10.1007/s10980-019-00829-4

Vincenot D, Normand F (2009) Guide de production intégrée de mangues à la Réunion. CIRAD, Montpellier

Vreysen MJB, Robinson AS, Hendrichs J, Kenmore P (2007) Area-Wide Integrated Pest Management (AW-IPM): Principles, Practice and Prospects. In: Area-Wide Control of Insect Pests. Springer, Dordrecht, pp. 3-33

Waage J (1998) The future development of IPM. Entomologia Sin 5:257271. https://doi.org/10.1111/j.1744-7917.1998.tb00322.x

Waddington H, White H (2014) Farmer field schools: from agricultural extension to adult education. Syst Rev Sum 1. https://researchonline. 1shtm.ac.uk/id/eprint/4647439

Waddington H, Snilstveit B, Hombrados J, Vojtkova M, Phillips D, Davies P, White H (2014) Farmer field schools for improving farming practices and farmer outcomes: A systematic review. Campbell System Rev 10:335. https://doi.org/10.4073/CSR.2014.6

Wagner CH, Cox M, Robles JLB (2016) Pesticide lock-in in small scale Peruvian agriculture. Ecol Econ 129:72-81. https://doi.org/10.1016/ j.envpol.2016.05.011

Walter GH (2005) Insect Management and Ecological Research. Cambridge University Press

Warner KD, Daane KM, Getz CM, Maurano SP, Calderon S, Powers KA (2011) The decline of public interest agricultural science and the dubious future of crop biological control in California. Agr Hum Values 28:483-496. https://doi.org/10.1007/s10460-010-9288-4

Way MJ, van Emden HF (2000) Integrated pest management in practice pathways towards successful application. Crop Prot 19:81-103. https://doi.org/10.1016/S0261-2194(99)00098-8
Wearing CH (1988) Evaluating the IPM implementation process. Annu Rev Entomol 33:17-38 https://www.annualreviews.org/doi/pdf/10. 1146/annurev.en.33.010188.000313

Weiss A, Dripps JE, Funderburx J (2009) Assessment of implementation and sustainability of integrated pest management programs. Fla Entomol 92:24-28. https://doi.org/10.1653/024.092.0105

Wesseling C (2005) Human rights and environmental justice in pesticide issues: Examples of inequities from Central America. Epidemiology 16:S72-S73

Wezel A, Bellon S, Doré T, Vallod D, David C (2009) Agroecology as a science, movement or practice. Agron Sustain Dev 29:503-515. https://doi.org/10.1051/agro/2009004

Wezel A, Casagrande M, Celette F, Vian J-F, Ferrer A, Peigne J (2014) Agroecological practices for sustainable agriculture. A review. Agron Sustain Dev 34:1-20. https://doi.org/10.1007/s13593-0130180-7

Whiteker GT (2019) Applications of the 12 Principles of Green Chemistry in the Crop Protection Industry. Org Process Res Dev 23:2109-2121. https://doi.org/10.1021/acs.oprd.9b00305

Wildbolz T (1962) Über Möglichkeiten der Prognose und Befallsüberwachung und Über Toleranzgrenzen bei der Integrierten Schädlingsbekämpfung im Obstbau. Entomophaga 7: 273-283. https://doi.org/10.1007/BF02374369

Wille JE (1951) Biological Control of Certain Cotton Insects and the Application of New Organic Insecticides in Peru. J Econ Entomol 44:13-18. https://doi.org/10.1093/jee/44.1.13

Willey WRZ (1978) Barriers to the diffusion of IPM programs in commercial agriculture. In: Pest Control Strategies. New York Academic, pp. 285-308

Willett W, Rockström J, Loken B, Springmann M, Lang T, Vermeulen S, Garnett T, Tilman D, DeClerck F, Wood A, Jonell M (2019) Food in the Anthropocene: the EAT-Lancet Commission on healthy diets from sustainable food systems. The Lancet 393:447-492. https:// doi.org/10.1016/S0140-6736(18)31788-4

Wilson C, Tisdell C (2001) Why farmers continue to use pesticides despite environmental, health and sustainability costs. Ecol Econ 39: 449-462. https://doi.org/10.1016/S0921-8009(01)00238-5

Wyckhuys KAG, Aebi A, van Lexmond MFB, Bojaca CR, Bonmatin JM, Furlan L, Guerrero JA, Mai TV, Pham HV, Sanchez-Bayo F, Ikenaka Y (2020a) Resolving the twin human and environmental health hazards of a plant-based diet. Environ Int 144:106081. https:// doi.org/10.1016/j.envint.2020.106081

Wyckhuys KAG, Bentley JW, Lie R, Fredrix M (2018) Maximizing farm-level uptake and diffusion of biological control innovations in today's digital era. BioControl 63:133-148. https://doi.org/10. 1007/s10526-017-9820-1

Wyckhuys KAG, Heong KL, Sanchez-Bayo F, Bianchi FJJA, Lundgren JG, Bentley JW (2019a) Ecological illiteracy can deepen farmers' pesticide dependency. Environ Res Lett 14:093004. https://doi.org/ 10.1088/1748-9326/ab34c9

Wyckhuys KAG, Lu Y, Morales H, Vazquez LL, Legaspi JC, Eliopoulos PA, Hernandez LM (2013) Current status and potential of conservation biological control for agriculture in the developing world. Biol Control 65:152-167. https://doi.org/10.1016/j.biocontrol. 2012.11.010

Wyckhuys KAG, Lu Y, Zhou W, Cock MJW, Naranjo SE, Fereti A, Williams FE, Furlong MJ (2020b) Ecological pest control fortifies agricultural growth in Asia-Pacific economies. Nat Ecol Evol:1-9. https://doi.org/10.1038/s41559-020-01294-y

Wyckhuys KAG, O'Neil RJ (2007) Role of opinion leadership, social connectedness and information sources in the diffusion of IPM in Honduran subsistence maize agriculture. Int J Pest Manage 53:3544. https://doi.org/10.1080/09670870601033331

Wyckhuys KAG, Pozsgai G, Lovei GL, Vasseur L, Wratten SD, Gurr GM, Reynolds OL, Goettel M (2019b) Global disparity in public awareness of the biological control potential of invertebrates. Sci 
Total Enviro 660:799-806. https://doi.org/10.1016/j.scitotenv.2019. 01.077

Wyckhuys KAG, Sánchez-Bayo F, Aebi A et al (2021) Stay true to integrated pest management. Science 371:133-133. https://doi.org/ $10.1126 /$ science.abf8072

Wyss JH (2006) Screwworm eradication in the Americas. Ann NY Acad Sci 916:186-193. https://doi.org/10.1111/j.1749-6632.2000. tb05289.x

Young SL (2017) A systematic review of the literature reveals trends and gaps in integrated pest management studies conducted in the United States. Pest Manage Sci 73:1553-1558. https://doi.org/10.1002/ps. 4574

Zadoks JC (1981) EPIPRE: A Disease and Pest Management System for Winter wheat Developed in the Netherlands. EPPO Bull 11:365369. https://doi.org/10.1111/j.1365-2338.1981.tb01945.x

Zalom FG (1993) Reorganizing to facilitate the development and use of integrated pest management. Agric Ecosyst Environ 46:245-256. https://doi.org/10.1016/0167-8809(93)90028-N

Zalucki MP, Adamson D, Furlong MJ (2009) The future of IPM: whither or wither? Austr J Entomol 48:85-96. https://doi.org/10.1111/j. 1440-6055.2009.00690.x
Zehnder G, Gurr GM, Kuhne S, Wade MR, Wratten SD, Wyss E (2007) Arthropod pest management in organic crops. Annu Rev Entomol 52:57-80. https://doi.org/10.1146/annurev.ento.52.110405.091337

Zhang W, Jiang FB, Ou FJ (2011) Global pesticide consumption and pollution: With China as a focus. Proc Int Acad Ecol Environ Sci 1:25-144 https://www.researchgate.net/publication/228841853

Zhang W, Ricketts T, Kremen C, Carney K, Swinton S (2007) Ecosystem services and dis-services to agriculture. Ecol Econ 64:253-260. https://doi.org/10.1016/j.ecolecon.2007.02.024

Zhang W, Lu Y, van der Werf W, Huang J, Wu F, Zhou K, Deng X, Jiang YWK, Rosegrant MW (2018) Multidecadal, county-level analysis of the effects of land use, Bt cotton, and weather on cotton pests in China. Proc Nat Acad Sci 115:E7700-E7709. https://doi.org/10. 1073/pnas.1721436115

Zhao Z-H, Reddy GVP, Hui C, Li B (2016) Approaches and mechanisms for ecologically based pest management across multiple scales. Agric Ecosyst Environ 230:199-209. https://doi.org/10.1016/j. agee.2016.06.010

Publisher's note Springer Nature remains neutral with regard to jurisdictional claims in published maps and institutional affiliations. 